\title{
Occupational Fraud: Executive Compensation and Enforcements Against Auditors and Perpetrators.
}

\author{
Erlina Papakroni \\ West Virginia University, epapakro@mix.wvu.edu
}

Follow this and additional works at: https://researchrepository.wvu.edu/etd

Part of the Accounting Commons, Finance and Financial Management Commons, Nonprofit

Administration and Management Commons, and the Portfolio and Security Analysis Commons

\section{Recommended Citation}

Papakroni, Erlina, "Occupational Fraud: Executive Compensation and Enforcements Against Auditors and Perpetrators." (2019). Graduate Theses, Dissertations, and Problem Reports. 4112.

https://researchrepository.wvu.edu/etd/4112

This Dissertation is protected by copyright and/or related rights. It has been brought to you by the The Research Repository @ WVU with permission from the rights-holder(s). You are free to use this Dissertation in any way that is permitted by the copyright and related rights legislation that applies to your use. For other uses you must obtain permission from the rights-holder(s) directly, unless additional rights are indicated by a Creative Commons license in the record and/ or on the work itself. This Dissertation has been accepted for inclusion in WVU Graduate Theses, Dissertations, and Problem Reports collection by an authorized administrator of The Research Repository @ WVU.

For more information, please contact researchrepository@mail.wvu.edu. 


\title{
Occupational Fraud: Executive compensation and enforcements against auditors and perpetrators.
}

\author{
Erlina Papakroni \\ Dissertation submitted \\ to John Chambers College of Business and Economics \\ at West Virginia University \\ in partial fulfillment of the requirements for the degree of \\ Doctor of Philosophy in \\ Business Administration - Accounting \\ Richard A. Riley Jr., Ph. D., Chair \\ Richard B. Dull, Ph. D. \\ Trevor L. Sorensen, Ph. D. \\ Lisa M. Dilks, Ph. D. \\ Department of Accounting
}

Morgantown, West Virginia

2019

Keywords: occupational fraud, executive compensation, SEC enforcements, independent auditor, principal perpetrators.

Copyright (C) 2019 Erlina Papakroni 


\section{ABSTRACT \\ Occupational Fraud: Executive compensation and enforcements against auditors and perpetrators.}

\section{Erlina Papakroni}

This dissertation is comprised of three studies that examine the association of executive compensation with financial statement fraud and enforcements pursued against the independent auditor and the principal perpetrators when occupational fraud is detected.

The first study examines competing, though non-mutually exclusive, hypotheses for the path that equity compensation follows on its way to financial misreporting. We find that firms that experience financial statement fraud pay their executives higher levels and a higher proportion of equity compensation across the entire executive's tenure. This starts in the first year of an executive's tenure and continues up until the fraud period. These findings hold across executive roles and pay rank. We find some evidence that executives who perpetrate fraud have idiosyncratic compensation preferences and negotiate different pay packages compared to other executives in the same firm. We find this only for option grants during the latter years of executive tenure. Finally, we find differences in how executives who perpetrate fraud manage their portfolios. They sell far less of their accumulated equity during their tenure than other executives in the same firm who do not perpetrate fraud.

The second study examines whether the U.S. Security and Exchange Commission's auditor related findings, namely charged, silent or concealed, are associated with fraud scheme characteristics, as argued under an outcome-penalty accountability framework. The results indicate a weak association between the fraud characteristics and the SEC's auditor related findings. Collusion among perpetrators and asset misreporting fraud schemes increase the probability of the SEC charging the auditor, as compared to the probability of being silent. Whereas the perpetrator's executive position decreases the probability of the SEC charging the auditor, as compared to the probability of being silent. Overall, only a few fraud characteristics affect the SEC's auditor related findings, which is not consistent with the outcome-penalty accountability framework. In contrast, the auditor type, being a Big-N auditor or not, significantly affects the SEC's findings. The SEC is more likely to remain silent or find that the fraud scheme is concealed for Big-N than non-Big$\mathrm{N}$ auditors, as compared to charging the auditor. Thus, this evidence is more consistent with a process-reward accountability framework.

Lastly, study three examines the impact of fraud severity and the perpetrator's status and organization type on the victim organization's outcomes pursued against the principal perpetrator. We find that as fraud severity increases, the severity of the outcome pursued against the principal perpetrator increases as well. Supporting status characteristics theory, we also show that perpetrators of different social statuses receive differing levels of punishment. Specifically, victim organizations pursue less severe outcomes against a perpetrator with a high status as compared to a perpetrator with a low status when the duration of the fraud is short. As the fraud duration increases, however, victim organizations pursue equally severe outcomes against all perpetrators. Lastly, governmental, not-for-profit, and privately held organizations are more likely to pursue no outcome than to terminate the principal perpetrator, as compared to publicly traded organizations. 


\section{DEDICATION}

To my dear parents, Vangjel and Naunka Rrushi, who taught me the importance of education.

To my loving husband, Vasil Papakroni, who supported me unconditionally during my studies.

Mami, babi dhe Vaso, faleminderit nga zemra! 


\section{ACKNOWLEDGEMENTS}

During my doctoral studies I have benefitted from the help, guidance and support of many people. I would first like to extend my gratitude to my dissertation chair, Dr. Richard A. Riley Jr., for his mentorship throughout my graduate studies. He showed me with great professionalism the path to become an independent and successful researcher.

I would also like to extend a special thank you to my members of the committee, Dr. Richard B. Dull, Dr. Trevor L. Sorensen and Dr. Lisa M. Dilks. I deeply appreciate your comments and suggestions which greatly improved this dissertation.

I would also like to acknowledge the support of all the faculty members and staff of the WVU Accounting Department during this seven-year long journey. Particularly, I would like to thank Dr. Presha Neidermeyer, who was the first to see the potential of an accounting Ph.D. student in me, and professor Nancy P. Lynch, who drilled the accounting knowledge into me, and later shared her great deal of teaching experience with me.

The friendship and encouragement of my fellow Ph.D. students, through good and not-so-good days, kept me sane. I treasure the best memories with my accounting, marketing, management and finance Ph.D. students.

Last, but not least, I wish to express my deep appreciation for my family. This journey would not have been possible without the support of my loving husband, Vasil. Thank you for believing in me, for encouraging me, for being patient with me, and for loving me each and every day. You have truly been there for me in health and in sickness. You are the best husband I could have wished.

A very special acknowledgment goes to my sister-in-law, Jorida, who was the first one to see that accounting was the best fit for me. Your help has been never ending since the first day I decided to pursue graduate studies in the U.S.A.

I would like to thank my parents, Vangjel and Naunka, who taught me the importance of education and who have worked tirelessly to provide me the best education possible. You are my role models. I would also like to thank my sisters, Alma and Aurora, and their loving families, for their love and support, and never getting tired of hearing about my school assignments.

To my extended family in Boston, especially my aunt Mimoza, you have been my home away from home - always welcoming me with open arms.

Also, a big thank you goes to all my friends in Morgantown, Pittsburgh and in Albania. All your support has meant the world to me.

Finally, to my two cats, Foo and Figaro, you have been my best companions, during long days and sleepless nights. You never showed a single sign of boredom, or interest for that matter.

Shumë faleminderit të gjithëve! 


\section{TABLE OF CONTENTS}

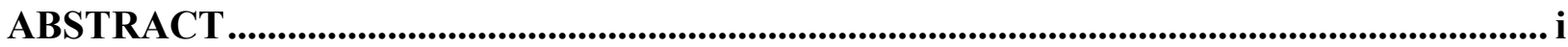

DEDICATION................................................................................................................................. iii

ACKNOWLEDGEMENTS ...................................................................................................... iv

LIST OF FIGURES .............................................................................................................. vii

LIST OF TABLES ................................................................................................................ vii

CHAPTER ONE: INTRODUCTION................................................................................ 1

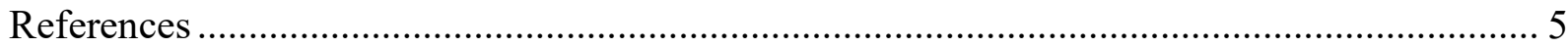

CHAPTER TWO: EXECUTIVE COMPENSATION AND FINANCIAL

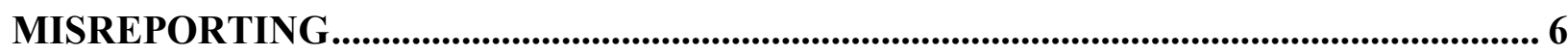

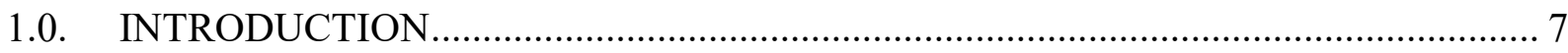

2.0. RELATED LITERARURE AND HYPOTHESIS DEVELOPMENT ............................ 11

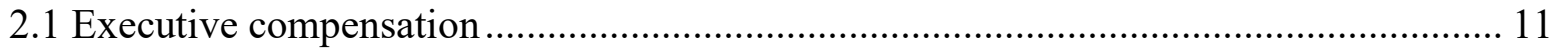

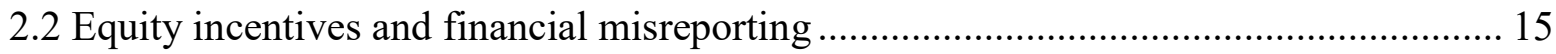

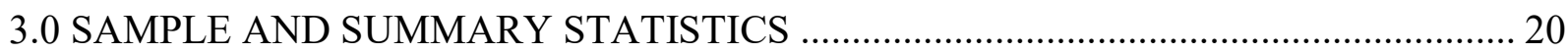

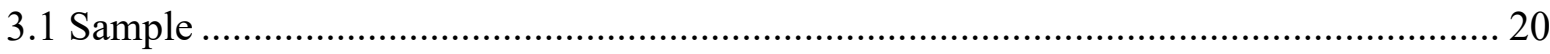

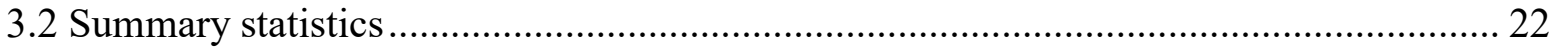

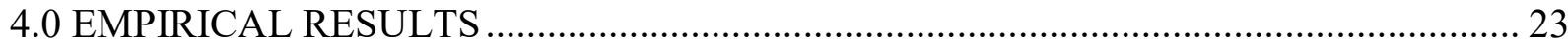

4.1 Compensation differences in fraud and non-fraud firms ............................................. 23

4.2 Compensation differences within fraud firms ......................................................... 26

4.3 Differences in diversification and portfolio management ............................................. 28

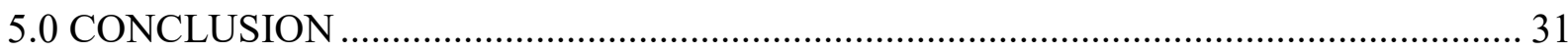

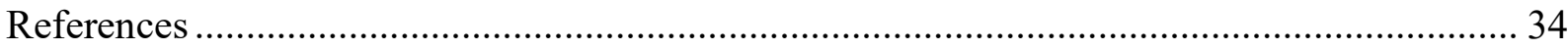

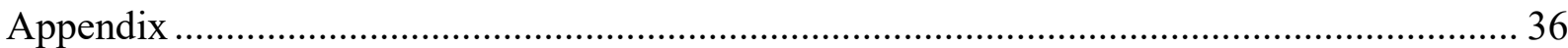

CHAPTER THREE: FRAUD CHARACTERISTICS AND SEC ENFORCEMENTS AGAINST INDEPENDENT AUDITORS .................................................................................. 47

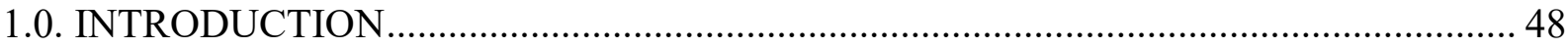

2.0 THEORETICAL BACKGROUND AND HYPOTHESIS DEVELOPMENT ................... 52

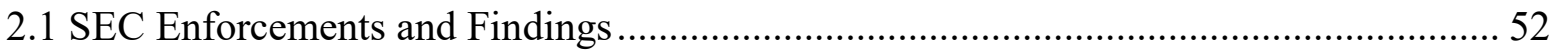

2.2 SEC Enforcements and Accountability Framework...................................................... 54

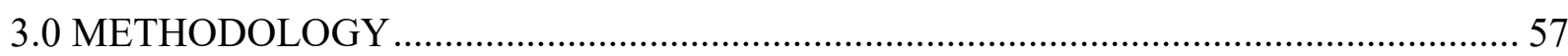

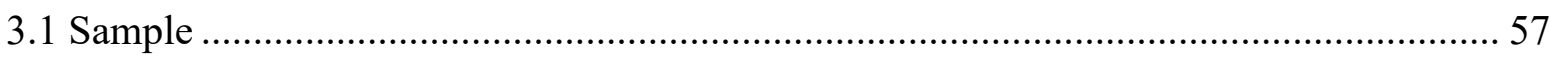

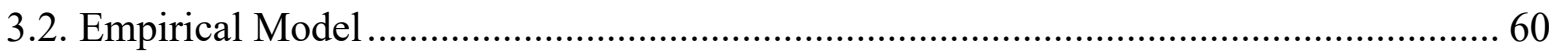




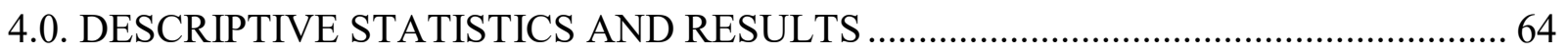

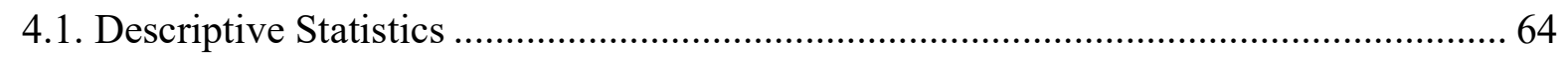

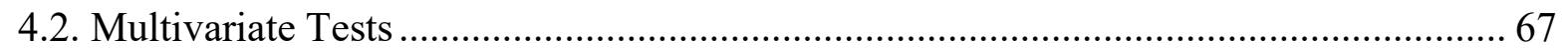

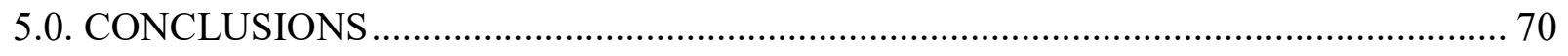

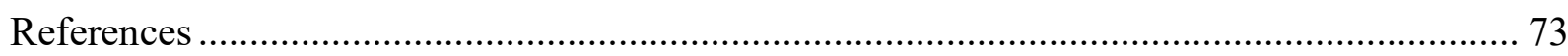

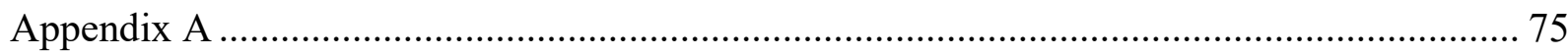

CHAPTER FOUR: FRAUD VICTIM ORGANIZATION: TO PUNISH, OR NOT TO PUNISH? THAT IS THE QUESTION....................................................................................... 84

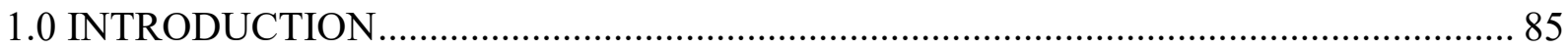

2.0 THEORETICAL BACKGROUND AND HYPOTHESIS DEVELOPMENT ................... 89

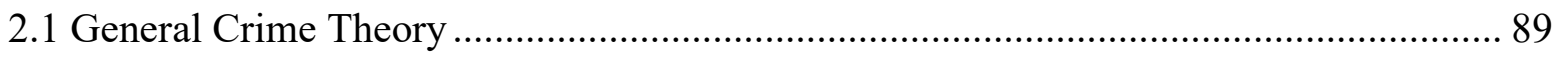

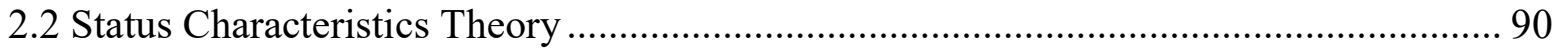

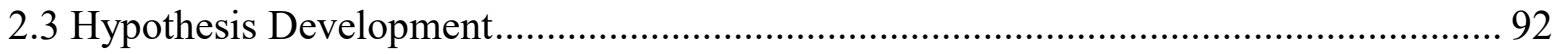

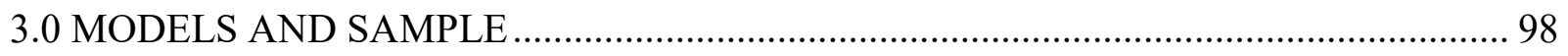

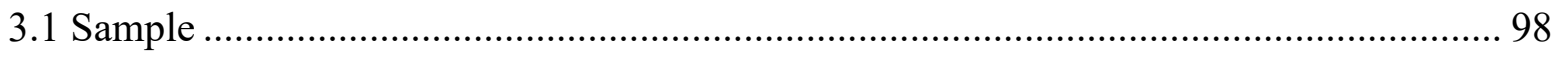

3.2. Empirical Model ................................................................................................ 99

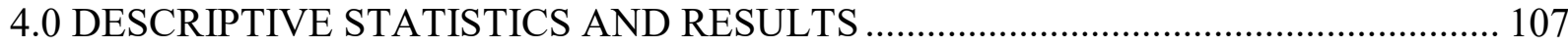

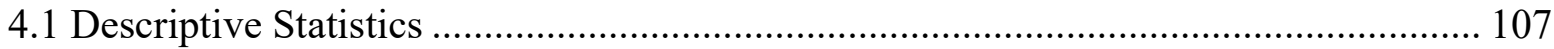

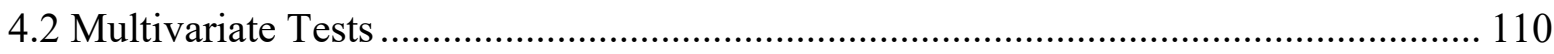

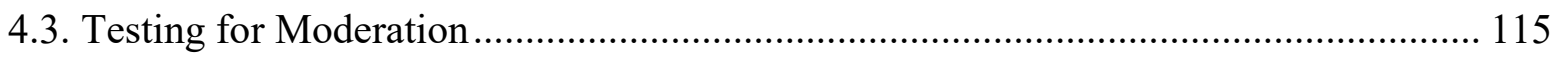

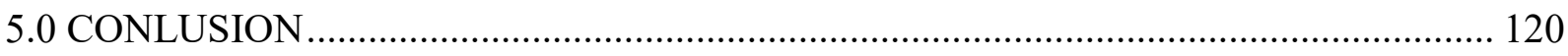

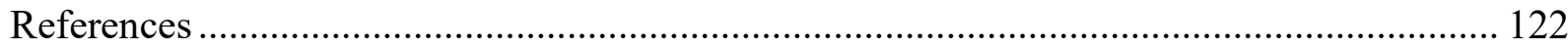

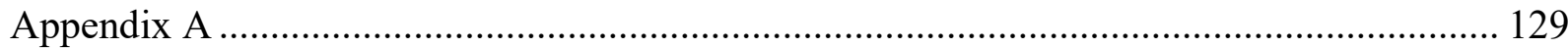

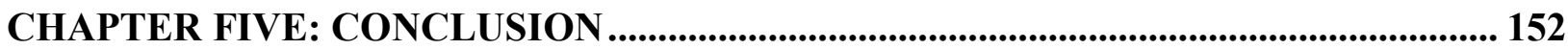




\section{LIST OF FIGURES}

Figure 2 - 1: Cumulative Compensation for Fraud and Non-Fraud Firm CEOs ........................ 37

Figure 2 - 2: Cumulative Compensation for Fraud and Non-Fraud Firm Non-CEOs .................. 38

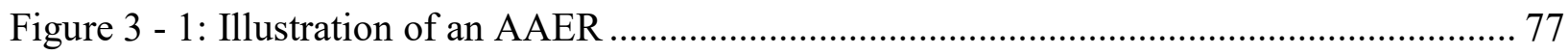

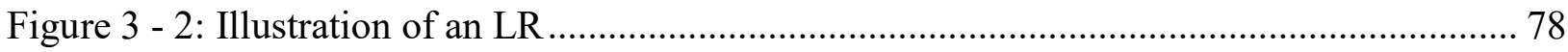

Figure 4 - 1: General Crime Theory developed in Criminology Literature.............................. 131

Figure 4 - 2: Theoretical Model of Fraud Outcome Determinants ........................................ 132

Figure 4 - 3: Graph Theoretic Representation of one Actor Salient ...................................... 133

Figure 4 - 4: Graphing Interaction - Pr (Termination and Criminal Prosecution) ................... 134

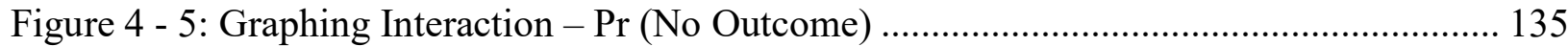

Figure 4 - 6: Graphing Interaction $-\operatorname{Pr}$ (Termination and Criminal Prosecution) .................... 136

Figure 4 - 7: Graphing Interaction $-\operatorname{Pr}$ (No Outcome) .................................................... 137

Figure 4 - 8: Graphing Interaction $-\operatorname{Pr}$ (Termination and Criminal Prosecution) .................... 138

Figure 4 - 9: Graphing Interaction - $\operatorname{Pr}$ (Termination and Criminal Prosecution) ................... 139

Figure 4 - 10: Graphing Interaction - Pr (Termination and Criminal Prosecution) .................. 140 


\section{LIST OF TABLES}

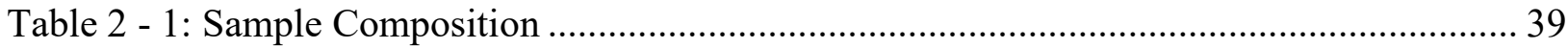

Table 2 - 2: Summary Statistics - Executive-Level Variables ....................................................... 40

Table 2 - 3: Executive Compensation in Fraud and Non-Fraud Firms.......................................... 41

Table 2 - 4: CEO Compensation by Tenure Year in Fraud and Non-Fraud Firms......................... 42

Table 2 - 5: Non-CEO Compensation by Tenure Year in Fraud and Non-Fraud Firms ............... 43

Table 2 - 6: Executive Compensation Within Fraud Firms ............................................................ 44

Table 2 - 7: Executive Compensation by Tenure Year Within Fraud Firms ................................... 45

Table 2 - 8: Portfolio Management Within Fraud Firms ............................................................... 46

Table 3 - 1: Studies Examining SEC Enforcements Against the Independent Auditor................ 79

Table 3 - 2: Descriptive Statistics for Full Sample and by SEC's Auditor Related Findings ....... 80

Table 3 - 3: Pearson Correlation Coefficients............................................................................. 82

Table 3 - 4: Multinomial Logit Regression - SEC's Auditor Related Findings and Fraud

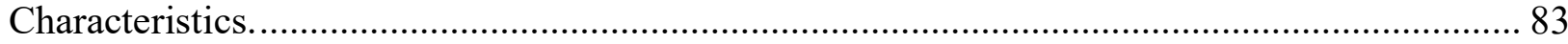

Table 4 - 1: Full Sample - Descriptive Statistics....................................................................... 141

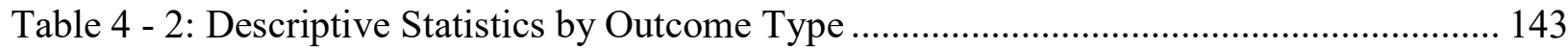

Table 4 - 3: Pearson (Upper)/ Spearman (Lower) Correlation Coefficients................................. 145

Table 4 - 4: Multinomial Logit Regression for Outcome Pursued and Fraud Severity, Perpetrator

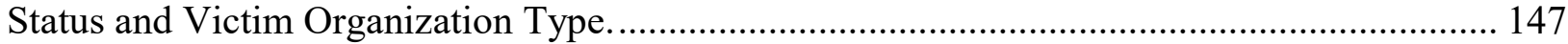

Table 4 - 5: P's Aggregate Expectations............................................................................... 148

Table 4 - 6: Multinomial Logit Regression for Outcome Pursued and Fraud Severity, Perpetrator

Status and Victim Organization Type.................................................................................. 149

Table 4 - 7: Multinomial Logit Regression for Outcome Pursued and Fraud Severity, Perpetrator

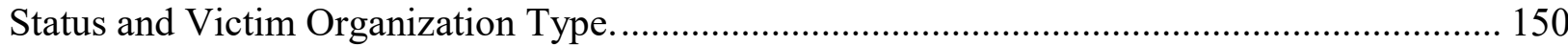




\section{CHAPTER ONE: INTRODUCTION}

Occupational fraud has serious consequences to individuals and/or organizations perpetrating the fraud schemes. Regarding individual consequences, Beasley, Carcello, Hermanson and Neal (2010), in analyzing public companies charged with fraudulent financial reporting from 1998 to 2007 by the U.S. Securities and Exchange Commission (SEC), found that in total $\$ 2.74$ billion in civil fines and \$2.65 billion in disgorgement were imposed on individuals allegedly involved. Further, individuals involved can experience high employment turnover, criminal indictments and convictions. Similar consequences are identified by Karpoff, Lee and Martin (2008b) where 93.4 percent of culpable individuals lost their jobs, 31 percent were barred from future employment by the SEC and 28 percent suffered criminal violations with sentences varying on average from 4.3 years in jail and 3 years in probation. Organizations receive severe consequences as well. The most immediate and prominent cost is stock price drop by an abnormal 16.7 percent within two days of fraud disclosure in the press and 7.3 percent within two days of the fraud investigation announcement by the SEC or the Department of Justice (DOJ) (Beasley et al. 2010). Additionally, Karpoff, Lee and Martin (2008a) estimated that for every fraudulent dollar, the firm losses that dollar plus an additional \$3.08. Most of the additional costs results from the lost reputation, $\$ 2.71$, and the remaining part of $\$ 0.36$ is the result of expected legal penalties. Despite these severe consequences, occupational fraud still prevails.

The purpose of this dissertation is to shed light into understanding the factors that allow or prevent fraudsters from perpetrating fraud. Chapter 2 examines executive compensation incentives in fraudulent firms, or lack of such incentives in control firms. Prior literature documents a positive association between executives' incentive compensation and financial misreporting but has not examined why executives in the misreporting firms have stronger equity incentives or how the 
compensation differences arise to the point where some executives manipulate the financial statements. This chapter provides insights into the changes of executive compensation packages, preceding the disclosure of financial statement fraud (FSF). For the period leading to FSF disclosure, this study examines whether executive compensation packages in fraud firms differ from the control firms, whether executives within fraud firms receive different compensation packages, and whether executives within fraud firms manage their portfolio overtime. We use Accounting and Auditing Enforcement Releases (AAERs) issued by the SEC as a proxy for financial statement fraud. We collect compensation data from Compustat's Execucomp database and supplement this data with hand collection from definitive proxy statements (filing DEF 14A). Other data used in our analyses are collected from Compustat and CRSP. We find strong evidences that misreporting firms pay their executives higher levels of equity compensation on average over entire executive's tenure. The difference in stock options granted to executives at fraud firms is greater than the difference in base salary, bonuses, and restricted stock grants combined across all years of their tenure. Further, when analyzing executive-level pay differences within misreporting firms, we find that executives who perpetrate fraud negotiate different levels of equity compensation compared to presumably innocent executives across their total tenure. Lastly, we find strong evidence that within misreporting firms, named executives retain a significantly higher percentage of their equity-based compensation than non-named executives, in total. The evidence indicates that how executives manage their portfolios influences the future reporting risk regardless of how firms choose to compensate their executives.

Chapter 3 examines fraud preventing factors related to independent auditors. Independent auditors are important gatekeepers in preventing publicly traded companies from misreporting their financial statements. The quality of the audit that the independent auditor provides is affected 
by the enforcements of the regulatory entities. Prior literature examines the U.S. Security and Exchange Commission's (SEC) enforcements, and argue that sometimes the SEC charges the auditor, and sometimes does not charge the auditor for auditing violations. Yet, evidence shows that, when the auditor is not charged, the SEC either finds that the fraud scheme is concealed from the auditor or remains silent regarding the auditor when there is no such finding. This chapter examines the enforcements issued by the SEC against the independent auditors for failing to detect fraud, namely charged, silent or concealed. Peecher, Solomon and Trotman (2013) argues two accountability frameworks, namely outcome-penalty framework and process-reward framework. The outcome-penalty accountability framework argues that the SEC's auditor related findings are associated with fraud schemes characteristics, and independent auditors are penalized based on their audit procedure outcomes. Whereas, the process-reward accountability framework argues that independent auditors are rewarded based on their audit process regardless of the audit outcome. Overall, only a few fraud characteristics affect the SEC's auditor related findings, which is not consistent with the outcome-penalty accountability framework. In contrast, the auditor type, being a Big-N auditor or not, significantly affects the SEC's findings. Big-N auditors are argued to provide better quality audits in prior studies. Thus, this evidence is more consistent with a process-reward accountability framework.

Lastly, chapter 4 examines outcomes perpetrators face from the victim organizations as a fraud deterrence factor. When occupational fraud is detected, the organization-the victim to the fraud case - decides whether to pursue no outcome, to terminate, or to terminate and criminally prosecute the principal perpetrator. We use ACFE survey data to examine the impact of fraud severity and the perpetrator's status and organization type on the victim organization's decisions in pursuing an outcome against the principal perpetrator. We examine whether perpetrator status 
characteristics and victim organization type interact with fraud scheme severity to affect outcome severity in occupational fraud cases. Each of these elements has previously been shown to be associated with punishment severity, but no prior study has examined the interaction of the three in white-collar crime. We find that as fraud severity increases, the severity of the outcome pursued against the principal perpetrator increases as well. However, victim organizations pursue less severe outcomes against high status perpetrators, as compared to low status perpetrators in fraud cases with a short duration. As the fraud duration increases, however, victim organizations pursue equally severe outcomes against all perpetrators. Lastly, different organization types pursue different outcomes for similar fraud acts. We conclude that the fraud outcome is determined not only by the severity of the fraud act, but also by the status of the perpetrator who committed the fraud and the type of the victim organization.

The rest of this dissertation is organized as follows. Chapter 2 through chapter 4 present the three studies briefly introduced in this chapter, and chapter 5 provides a summary of conclusions and main contributions for each study. 


\section{References}

Beasley, M., J. Carcello, D. Hermanson, and T. Neal. 2010. Fraudulent Financil Reporting, 1998 -2007: An Analysis of U.S. Public companies. Committee of Sponsoring Organizations of the Treadway Commission.

Available at: http://www.coso.org/documents/cosofraudstudy2010 001.pdf

Karpoff, Jonathan M., D. Scott Lee, and Gerald S. Martin. 2008a. The cost to firms of cooking the books. Journal of Financial and Quantitative Analysis 43(03): 581-611.

Karpoff, J. M., Lee, D. S., \& Martin, G. S. 2008b. The consequences to managers for financial misrepresentation. Journal of Financial Economics, 88(2), 193-215.

Peecher, M. E., I. Solomon, and K. T. Trotman. 2013. An accountability framework for financial statement auditors and related research questions. Accounting, Organizations and Society 38 (8):596-620. 


\title{
CHAPTER TWO: EXECUTIVE COMPENSATION AND FINANCIAL MISREPORTING
}

\author{
Robert H. Davidson* \\ Pamplin School of Business, Virginia Polytechnic Institute and State University \\ rhdx@vt.edu \\ Erlina Papakroni \\ John Chambers College of Business and Economics, West Virginia University \\ epapakro@mix.wvu.edu
}




\subsection{INTRODUCTION}

Many empirical studies document a positive association between incentives from an executive's firm-based wealth and financial misreporting. These studies have examined different proxies for equity incentives, different types of financial misreporting, and different executive roles, and they have employed various econometric techniques. Thus far, the literature has not examined why executives in the misreporting firms have stronger equity incentives or how the compensation differences arise to the point where some executives within the firm manipulate the firm's financial statements. We look to fill this void and explore competing, though non-mutually exclusive, hypotheses for the path that equity compensation follows on its way to financial misreporting.

We consider three explanations for the hypothesized positive association between equity-based compensation and financial misreporting. The first is that future misreporting firms unilaterally choose or need to offer higher equity compensation to prospective hires. Board of directors in these misreporting firms may have specific strategies and preferences for risk, and they want to pursue and pay their executives accordingly. Alternatively, these firms may need to offer high powered equity incentives to attract talent. This suggests that under either scenario these firms pay all their executives a higher level and/or proportion of equity compensation throughout their tenure at the firm. Thus, initially we examine compensation differences between misreporting and control firms for all executives during their entire tenure with the respective firm.

Most prior research in this area has concentrated on CEO equity incentives, but recent papers have begun to distinguish between executive roles. For instance, Feng, Ge, Luo and Shevlin (2011) find that equity incentives are positively related to misreporting for CEOs but not for CFOs. Jiang, Petroni and Wang (2010) find the opposite result, a positive association for CFOs and no 
association for CEOs. Davidson (2018) finds that within misreporting firms those executives named by the SEC as fraud perpetrators have stronger equity incentives than other presumably innocent executives at the same firm regardless of their role. This suggests that differences in equity incentives across executives in the same firm could be related to reporting risk in addition to or instead of differences in pay preferences at the firm level. Thus, next, we examine compensation differences between misreporting and control firms for CEO and non-CEO executives in each of the first 10 years of their tenure with the respective firms.

The next two explanations we consider address within-firm differences in equity incentives across executives ${ }^{1}$. The second explanation is that executives who perpetrate fraud have different compensation preferences and negotiate pay packages with higher levels or ratios of equity compensation. Compensation is a negotiation between the firm and the individual; as such, at the executive level, the employee will often have the ability to negotiate higher pay or a different mix of base and incentive-based pay (Murphy 2013). Under this explanation, we examine compensation differences between executives who are named and executives who are not named as fraud perpetrators by the SEC. Compensation differences are examined for the entire tenure and for each individual year for the first 8 years of the executive's tenure with the fraud firm.

The third explanation is that regardless of across or within firm pay differences, executives who perpetrate reporting fraud have strong equity incentives because of how they manage their portfolio over time. Many managers hold much of their wealth in their firm's stock (Armstrong, Core and Guay 2015), but there is substantial variation across executives. If certain executives

\footnotetext{
1 Another possibility, that fraud is perpetrated by executives with higher tenure and greater equity incentives, strictly because of tenure differences, does not appear likely. The Report to the Nations finds that percentage of frauds committed by executives in their first 5 years of tenure is nearly the same as the percentage committed by executives after their fifth year at the job (50.6\% to $49.4 \%$ respectively). Additionally, we either control for tenure or compare compensation at the same point during tenure to address the impact that tenure has on compensation.
} 
rarely divest themselves of equity-based compensation, then over time the value of their firmbased wealth and any incentives it creates will grow regardless of firm or executive specific compensation differences. Therefore, we examine whether differences in how executives, within fraud firms, manage their equity portfolios are associated with the misreporting risk. These differences are examined, in total, for all executive tenure years after year 5 .

We find strong evidences that misreporting firms pay their executives higher levels of equity compensation on average over entire executive's tenure. On average, CEOs (non-CEOs) at fraud firms are paid an additional $\$ 3.6$ million $(\$ 900,000)$ per year, with $50(65)$ percent of that attributed to stock options. The difference in stock options granted to executives at fraud firms is greater than the difference in base salary, bonuses, and restricted stock grants combined across all years of their tenure. When examining each tenure year individually, this difference is significant, beginning in the first year of an executive's tenure, and it grows throughout their tenure at the firm. These results hold regardless of the executive's role and hold also for executives who left the firm years before the misreporting period. In summary, irrespective of the time, role, or tenure, eventual misreporting firms are paying their executives higher equity compensation, which is one potential source of the documented positive association between equity incentives and misreporting.

When analyzing executive-level pay differences within misreporting firms, we find some evidence that executives who perpetrate fraud negotiate different levels of equity compensation compared to presumably innocent executives across their total tenure. Specifically, we find that named executives are awarded approximately $\$ 900,000$ more in stock options over their total tenure than non-named executives in the same firm, but this difference is largely determined by differences during the latter years of their tenure (years 6-8). When considering annual pay differences separately for each tenure year, we find no difference in any year for salary, bonus, or 
restricted stock grants between named and non-named executives. However, we find that named executives are awarded significantly larger stock option grants in 4 out of 8 years of their tenure. We interpret these findings as evidence that differences between fraud and non-fraud firms are driven by both firm-level and executive-level compensation preferences, but that cross-sectional differences in pay are larger and more robust than within-firm differences in pay.

Finally, we find strong evidence that within misreporting firms, named executives retain a significantly higher percentage of their equity-based compensation than non-named executives, in total, for all executive tenure years after year 5. Given that executives hired externally generally have not previously held stock, we do not examine portfolio management during the earliest years of tenure, however we find evidence that named insiders sell a lower percentage of their equity, starting in the sixth year of their tenure and as the fraud period approaches. The evidence indicates that how executives manage their portfolios influences the future reporting risk regardless of how firms choose to compensate their executives.

In sum, we find at least some evidence for three distinct explanations, that could lead to a positive association between equity incentives and misreporting - that misreporting firms prefer to pay their executives differently, that executives who perpetrate fraud negotiate contracts with a higher level of option grants, and that executives who perpetrate fraud diversify themselves less and manage their portfolios differently from other executives. The results suggest that actions by both the firm and the executives contribute to an environment where misreporting is more likely, and that pay practices by themselves may not significantly increase the fraud risk level if certain portfolio practices by executives are absent. The results are of interest to regulators, board of directors, investors, and managers who should consider how effective changes to compensation 
mix or levels impact reporting risk when there are no changes in how some executives manage their portfolios.

The rest of the paper is organized as follows. Section 2 discusses the relevant literature and develops testable hypotheses, Section 3 discusses the same and provides summary statistics, Section 4 presents the results, and Section 5 concludes.

\subsection{RELATED LITERARURE AND HYPOTHESIS DEVELOPMENT}

\subsection{Executive compensation}

Top executives' total compensation has increased rapidly over the past 30 years (Frydman and Jenter 2010), and the increase has been considerably higher than inflation, at times (Goergen and Renneboog 2011). Not only total compensation, but the composition of compensation packages has changed as well. Most common executive compensation packages include base salary, annual bonus, stock and stock options, insurance, pensions benefits, and severance pay (Bushman, Indjejikian and Smith 1996). Over the past 30 years, base salary has accounted for a steadily decreasing percentage of executive total pay, whereas stock options have accounted for a steadily increasing percentage (Goergen and Renneboog 2011). The use of equity-based compensation for the top executives rose dramatically in the late 1980s and early 1990s. The median CEO wealth determined by the stock market performance of the firm tripled between 1980 and 1994, and then it doubled again between 1994 and 2000 (Bergstresser and Philippon 2006; Hall and Liebman 1998). Prior studies find that equity accounts for most of the executive's compensation. For instance, Armstrong et al. (2015) examine a sample of US CEOs from 1994 to 2010 and find that on average the CEO holds about $\$ 41.7$ million of equity in the organization. Executive compensation is constantly changing in response to the economic and political environments (Murphy 2013). The main purpose of these changes is to address the agency problem by aligning 
upper management equity incentives with the interest of shareholders in the organization. Yet, there is an ongoing debate in the corporate governance literature whether, at the current state, executive compensation is addressing or causing the agency problem.

The two opposing views on executive compensation, in the corporate governance literature, are the efficient contracting view and the managerial power view (Murphy 2013). Under the efficient contracting view, executive compensation is viewed as the market mechanism that aligns shareholders' and executives' interests (Goergen and Renneboog 2011) through its incentive components (i.e. stock and stock options), which expose executives to compensation risk through stock price movement (Bergstresser and Philippon 2006). This view maintains that incentives are structured to optimize firm value (Murphy 2013). The organization's financial performance is associated with stock price movements. Higher stock prices translate into higher compensation for the executives. Therefore, executives are incentivized to increase firm value, which aligns with shareholders' interests, in order to increase their compensation. In contrast, the managerial power view argues that executive compensation provides opportunity for managers to extract rents from shareholders (Goergen and Renneboog 2011) by manipulating the stock prices through reported earnings (Bergstresser and Philippon 2006). Executives are strongly incentivized to manipulate the financial statements to either maintain or to increase the stock price in order not to risk their compensation. Further, under this view, the level and the composition of the compensation are determined by powerful executives, not by the competitive market forces (Murphy 2013). Prior studies find that executives exercise significant power on governance mechanisms when negotiating the level and the composition of their compensation.

These two opposing views stem from the ongoing debate whether the executive compensation is the cause or the solution of the agency problem, i.e. the separation of ownership and 
management. The incentive components of the compensation are the solution to the agency problem, as management's interest is aligned with the shareholders' interest in increasing the firm value. Yet, setting the level and the composition of these incentives causes the agency problem. The shareholders engage the board of directors and other governance mechanisms to protect their interest in the organization (Brick, Palmon and Wald 2006). Thus, the agency problem pertains not only between the shareholders and the top executives, but also between the shareholders and the board of directors. The board of directors are elected by the shareholders to monitor, hire, fire, and set compensation for the top executives (Murphy 2013). Occasionally, the board of directors appoint compensation committees to set executive compensation. Also, they hire compensation consultants to assist them in designing compensation packages (Cadman, Carter, and Hillegeist 2010). Several studies find that these entities do not always act in the best interests of the shareholders, and the outside directors do not suffer significant wealth and reputational penalties in those cases (Beneish, Marshall and Yang 2017). Hence, the top executives have significant bargaining power in setting their compensation level and composition.

Goergen and Renneboog (2011) state that the boards of directors as well as their compensation committees are not effective corporate governance mechanisms, and there are several reasons cited in the literature. First, although on average the boards of directors consist of 80 percent of outside directors, and half of the time the CEO is the only inside director on the board, the CEO influences the director's nomination process (Murphy 2013). The directors are elected by the shareholders but are often selected by the CEO (Murphy 2013). As such, the directors are unlikely to challenge the CEO's compensation (Goergen and Renneboog 2011). Second, the CEO is not only involved in the hiring process of the directors, but also in setting their compensation, and Brick et al. (2006) find a positive association between the CEO's compensation and the directors' compensation. The 
authors further explain that the $\mathrm{CEO}$ overcompensates the directors in exchange for a less stringent monitoring, in a "mutual back scratching" relationship. At the same time, the directors are willing to over-compensate the top executives since they are using the shareholders' money and not their own (Murphy 2013). Third, the executives and directors share important social ties through serving together in other boards, working together in the past, or through other social events, such as golf outings, business roundtable meetings, serving in the same charitable organizations, etc. (Fracassi and Tate 2012). Hwang and Kim (2009) find that in only 62 percent of their sample, a director did not have any financial, familial, or social ties to the CEO or to the firm. Firms with boards that lack all these three ties award a lower level of compensation and exhibit stronger pay-performance sensitivity and stronger turnover-performance sensitivity than firms whose boards lack financial and familial ties but have social ties. Also, Fracassi and Tate (2012) find that the intensity of board monitoring is weakened in the organization where the CEO has prior ties the board members.

Prior literature finds shortcomings about compensation consultants as well. Compensation consultants assist organizations in setting and designing an executive compensation contract and offer several other services, such as accounting, tax and regulatory issues related to executive pay, and various human resources and actuarial services (Murphy and Sandino, 2010). Working closely with the management, not the board of directors, the compensation consultants face a conflict of interest in pleasing the management, by recommending excessive compensation in exchange for repetitive business and cross selling other services (Murphy and Sandino 2010). Cadman et al. (2010) fail to find an association between the compensation consultant's conflict of interest and the CEO's excessive pay, whereas Murphy and Sandino (2010) do find that the CEO's pay is higher in companies where the consultants provide other services. 


\subsection{Equity incentives and financial misreporting}

Accounting research has been concerned with the reasons why equity compensation not only fails to align principals' and agents' interests (as initially introduced by Jensen and Meckling, 1976) , but is also considered a source of the divergence in principals' and agents' interests. For instance, Jensen (2005) asserts that equity-based compensation fails to address the agency problem when the firm's equity is overvalued. As executives' pay and wealth compensation depend on overvalued stock, they have strong incentives to maintain overvaluation ${ }^{2}$.

Prior research has extensively analyzed the association between the financial misreporting and executive compensation. The financial misreporting has been measured using proxies for earnings management (abnormal accruals, meet/beat earnings forecasts), accounting restatements, and litigated cases of financial statement fraud. The executive compensation has been measured using components of pay, often focusing on performance-based pay (stock options, restricted stock, bonuses) or the sensitivity of firm-based wealth to stock prices (portfolio delta, vega). The findings generally document a positive association between CEO's equity incentives ${ }^{3}$ and earnings management (Bergstresser and Philippon 2006; Cheng and Warfield 2005), accounting restatements (Burns and Kedia 2006; Cheng and Farber 2008), and accounting fraud (Feng et al. 2011; Denis et al. 2006).

Recent evidence suggests that this association exists cross-sectionally among fraud and nonfraud firms and within misreporting firms across executives. Feng et al. (2011) find that CEOs, rather than CFOs in the misreporting firms, have significantly higher equity incentives than control

\footnotetext{
${ }^{2}$ Overvaluation can occur absent or prior to any manipulation of financial statements, legal or illegal, on the part of management.

${ }^{3}$ Prior research has examined the association between cash bonuses and misreporting but generally has failed to find significant results (Efendi et al. 2007; Harris and Bromiley 2007). Results in the literature are generally significant for incentives created from the total firm-based wealth and not for components of the current year compensation.
} 
firms. Davidson (2018) finds that the executives who perpetrate the misreporting scheme have higher equity incentives than non-perpetrating executives within the firm, regardless of an executive role. The evidence thus far indicates statistically significant differences in executives' equity incentives between financial misreporting firms and control firms.

However, there are two gaps in the established association that the accounting literature has yet to address. First, this association is primarily documented only for the year prior to the first misreported year. For instance, Efendi, Srivastava and Swanson (2007) find that the ratio of inthe-money options held by the CEO to the CEO's salary changes from 46.2 to 15.3 , in the year before and after the misstatement, respectively, while the same change is not observed in control firms. But incentives from firm-based wealth generally need to accrue over a number of years. RTTN (2016) reports that 49.4 percent of frauds are committed by individuals who have been at the firm for more than 5 years. Currently, there is a void in the extant literature in examining compensation differences between misreporting and control firms over the executives' tenure. Thus, there is little research on when or in what ways misreporting firms diverge from control firms regarding the executive compensation over the perpetrator's tenure. Second, there is still little consistent evidence regarding equity incentives and misreporting for non-CEOs. Davidson (2018) reviewed 18 studies that examined executive compensation and financial misreporting, and only 2 of those studies examined the compensation of non-CEO executives.

Prior research has more consistently found evidence of an association between financial misreporting and incentives from accumulated firm-based wealth as opposed to components of current period compensation ${ }^{4}$. This literature has not yet examined how perpetrators accumulated

\footnotetext{
${ }^{4}$ Prior research has examined changes in compensation packages following the revelation of financial misreporting. Cheng and Farber (2008) find a significant shift in compensation from options to salary after the revelation of accounting issues. Further, they find evidence that stock option grants are increasing during the misstatement period.
} 
their firm-based wealth and whether it is the outcome of firm-level compensation preferences, whether individual executives who perpetrate fraud have idiosyncratic compensation preferences and negotiate different pay packages, or whether differences in equity levels are caused not by compensation differences, but by executives divesting themselves of previously granted equity at significantly different rates. We develop three hypotheses, one for each of the three potential explanations.

While differences in firm-based wealth are affected by tenure and portfolio management, it is possible that firms offer similar annual compensation contracts to all senior executives. Prior studies analyzing misreporting and CEO equity incentives often find similar results when analyzing average equity incentives across the top 5 paid executives. Additionally, Jiang et al. (2010) find that firms that provide strong equity incentives for their CFOs tend to provide strong equity incentives throughout the organization. Given the evidence that fraud firm executives have strong equity incentives and that firms have specific compensation preferences, we propose the following hypothesis, stated in null form:

$\mathbf{H}_{1}$ : Misreporting firms do not offer greater equity incentives to their top-five paid executives than do control firms.

Prior research also suggests within-firm differences in equity incentives and that these differences are associated with reporting risk. Jiang et al. (2010) find evidence that CFO equity incentives are positively associated with misreporting but fail to find an association between CEO equity incentives and financial misreporting. In contrast, Feng et al. (2011) find no evidence of an association between CFO equity incentives and financial misreporting but do find a positive association between CEO equity incentives and misreporting. In comparing equity incentives within the misreporting firms, Davidson (2018) finds that executives, who the SEC identifies as 
perpetrators of fraud, have stronger equity incentives than non-perpetrators. Given prior findings regarding executive's ability to negotiate preferred pay packages and differences in equity incentives within fraud firms across executives, we consider the possibility that executives who perpetrate financial statement fraud negotiate pay packages with higher levels of stock or option grants, compared to other executives in the same firm. This leads to our second hypothesis, stated in null form:

H2: Executives named as perpetrators in misreporting firms do not have higher equity compensation than non-named executives in the same misreporting firms.

Armstrong et al. (2015) find that executives hold far more equity than it is required by explicit or implicit contracts but also document a significant variation in the level of equity that executives hold. Most executives will eventually sell some of their accumulated equity for liquidity, diversification, or other reasons. Cohen, Malloy and Pomorski (2012) analyze insiders' trading behavior and find that insiders who trade regularly in the same month every year are more likely trading for liquidity or diversification purposes while those who trade regularly with no identifiable pattern are more likely making informed trades for the purpose of profiting off their information advantage. Kallunki, Kallunki, Nilsson and Puhakka (2018) find differences in the executives' trading behavior based on their wealth.

Prior research documents a significant variation in equity holdings and insider trading across executives. Many prior studies examining the relation between financial misreporting and equity incentives measure equity incentives using some measure of wealth sensitivity to stock price (e.g. portfolio delta and vega). These measures are not compensation variables per se as executives are paid in stock and options, not in deltas and vegas; they are proxies for incentives from total firmbased wealth, which is equal to accumulated equity compensation from which any divestments, 
that the executive has made over their entire tenure (multiplied by stock price), has been deducted. Executives may accumulate and maintain strong equity incentives because of how they are paid or because of how they manage their portfolios. Thus, it is possible that any association between equity incentives and misreporting is not driven by particularly high levels of equity compensation but by particularly low levels of divestiture by executives after the fact. This leads to our third hypothesis, stated in null form:

H3: Executives in misreporting firms do not manage their firm-based wealth differently from executives in control firms.

In sum, an association between equity incentives and misreporting could exist because certain firms prefer paying their managers with higher levels of equity, certain executives prefer and negotiate pay with higher levels of equity, and certain executives manage their portfolios in a way that causes a variation. The existing theory predicting an association between equity incentives and misreporting makes no distinction as to the generation of relatively high levels of equity incentives, nor has the course been identified in empirical research.

It is also important to emphasize that it is well documented that financial misreporting occurs over time. Beasley et al. (2010), in the second COSO report 1998-2007, report that the average fraud period extends to 31.4 months, with a median of 24 months. In the first COSO report, 1987 - 1999, the average and median duration was slightly shorter: 23.7 and 21 months respectively. RTTN (2016) reports approximately the same median duration of 18 months, with a duration range from a couple of months up to more than 60 months. About $55 \%$ of the fraud cases in their sample lasted more than 12 months. Regarding restatements, Kedia and Philippon (2009) find that the average number of the restated period is 5 financial quarters, with a range from 1 to 60 quarters restated. Furthermore, executives have a tenure of several years with the misreporting firms. In a 
sample of 427 restating firms during the period 1993-2007, CEOs that were fired had a mean tenure of 6.6 years, whereas the CEOs that were retained had a mean tenure of 11.3 years (Beneish et al. 2017). Equity incentives are predicted to increase over the CEO's tenure because as their initial performance uncertainty decreases over the years, it is possible to impose a higher incentive risk, ceteris peribus (Erickson, Hanlon and Maydew 2006).

It is uncertain how equity compensation and its association to financial misreporting changes over the executive tenure. Given the several month-duration of the financial misreporting and the executives' multi-year tenure, we argue that differences in firm-based wealth between executives at fraud versus control firms take several years to become pronounced, could begin at various levels during executive tenure, and are caused by a combination of firm-based compensation preferences, idiosyncratic executive compensation preferences, and idiosyncratic executive portfolio management practices. Hence, we examine executive compensation differences separately for each executives' tenure year with the misreporting firm.

\subsection{SAMPLE AND SUMMARY STATISTICS}

\subsection{Sample}

We use Accounting and Auditing Enforcement Releases (AAERs) issued by the SEC as a proxy for financial statement fraud. These releases summarize investigations the SEC brings against firms and/or executives for violations of SEC and Federal rules. To collect the sample, we read AAERs 84 -3,916 which were released between January 15, 1986 and December 12, 2017. Firms are only included when the following can be determined: whether the firm's financial statements are materially misstated; the year the violation began; and the names of those who committed the fraud. 
Karpoff, Koester, Lee and Martin (2017) compare and note differences among numerous proxies used for misreporting. We chose to use the AAERs because several of our tests compare executives within a manipulation firm based on whether the individual was involved in perpetrating the fraud. AAERs are the only proxy that regularly provides this information. One limitation is that we assume the SEC accurately identifies perpetrators in fraud cases. This potential limitation introduces bias in our analyses only if the SEC intentionally charges individuals because they have high levels of equity. There is little evidence that individuals are wrongly named in AAERs and given the reputation and legal cost to the SEC for fining and/or jailing innocent executives, we assume that the SEC exercises extreme diligence before naming executives and imposing severe penalties on them. There is significant variation in the number of executives named in a given fraud case as well as significant variation in the roles of named parties. This suggests that the SEC is not simply naming and pursuing cases against executives in the same role in each firm but is investigating those executives for which there is strong evidence of their involvement.

Table 2 - 1 provides statistics on the AAER fraud firms in our sample. During the collection period there were 3,815 AAERs issued ${ }^{5}$. Of those, we are able to match 392 firms to Compustat and CRSP and collect compensation data during years before the manipulation period ${ }^{67}$. Compensation data are available for 2,903 executives at AAER firms, many of whom left the firm before the manipulation period began. Finally, compensation data is available for 627 executives who are named by the SEC in an AAER as a perpetrator of accounting fraud.

\footnotetext{
${ }^{5}$ As noted in prior studies, many AAERs are for matters unrelated to accounting fraud, and firms often have multiple AAERs associated with a single event.

${ }^{6} 5$ AAER firms with frauds related to earnings/asset understatement are excluded from the final sample.

${ }^{7}$ Some firms do not have compensation data available in the year immediately preceding the manipulation period, but data is available in earlier years to analyze compensation practices at different points during executive tenure.
} 
[Insert Table 2 - 1 here]

\subsection{Summary statistics}

We collect compensation data from Compustat's Execucomp database and supplement this data with hand collection from definitive proxy statements (filing DEF 14A), available from the SEC for fraud firms not included in Execucomp ${ }^{8}$. Other data used in our analyses are collected from Compustat and CRSP, and data sources are provided in the Appendix.

Table 2 - 2 presents mean and median values for executive-level variables across fraud and non-fraud firms. We present data for CEOs and other top 5 paid executives. Fraud firm CEOs have significantly higher total compensation (Total Comp), which appears to be driven by significantly higher bonuses (Bonus) and option grants (Option). Bonuses and option grants are approximately 50 percent higher for fraud firm CEOs. These differences are all significant at the 0.01 level for both means and medians. While fraud firm CEOs do have higher salaries (Salary) and restricted stock grants (Rstock), neither difference is statistically significant. The compensation differences are even more stark for non-CEOs ${ }^{9}$. Fraud firm non-CEOs also have higher bonuses and option grants at the 0.01 level for both means and medians but additionally have significantly higher mean salaries and restricted stock grants. Overall, this evidence suggests that fraud firms pay their executives higher levels of total compensation, which is mainly driven by large option grants.

Bottom part of Table 2 - 2 presents mean and median values for firm level variables across fraud and non-fraud firms. Fraud firms are significantly different than non-fraud firms. Fraud firms

\footnotetext{
${ }^{8}$ We collect this data for a number of firms in the Execucomp database to verify the accuracy and comparability of data from proxy filings with data from Execucomp.

${ }^{9}$ All compensation variables are expressed in thousands and are taken as the value would be presented in Execucomp. Variables are defined in the Appendix.
} 
are larger, with higher market to book ratios and higher stock returns. They also have lower debt ratios and operate in fewer geographic segments. As these variables are also associated with executive compensation, they represent important controls for our cross-sectional tests.

We also consider a time dimension to differences in compensation. Figures 2 - 1 and 2 - 2 display cumulative total compensation over CEO (Figure 2 - 1) and non-CEO (Figure 2 - 2) tenure across fraud and non-fraud firms. Both figures indicate that differences in compensation are present from the early years of tenure and continue to increase over time. Differences in CEO pay are large, begin in the first year of CEO's tenure, and grow at a close to constant rate through time. Differences in non-CEO pay are smaller during earlier tenure years, and the difference begins to grow at a much larger rate after the fifth year of tenure.

[Insert Table 2 - 2, Figure 2 - 1, and Figure 2 - 2 here]

\subsection{EMPIRICAL RESULTS}

\subsection{Compensation differences in fraud and non-fraud firms}

We test Hypothesis 1, whether fraud firms pay higher total compensation or higher components of compensation, by estimating the following equation:

$$
\begin{aligned}
\text { Comp }_{i, j, t}= & \beta_{1} \text { Fraud }_{j, t}+\beta_{2} \text { Size }_{j, t}+\beta_{3} \text { MTB }_{j, t}+\beta_{4} \text { Debt }_{j, t}+\beta_{5} \text { Return }_{j, t}+\beta_{6} \text { Volatility }_{j, t}+ \\
& \beta_{7} \text { Geographic }_{j, t}+\beta_{8} \text { Segment }_{j, t}+\beta_{9} \text { Tenure }_{i, j, t}+\beta_{10} \text { CEO }_{i, j, t}+\text { Industry FE }_{+} \\
& \text {Year FE }+\varepsilon_{i, t}
\end{aligned}
$$

Where Comp is either: Total Comp, Bonus, Salary, Rstock, or Option. Fraud is an indicator variable set to 1 if the executive works at a firm where fraud eventually occurs, and 0 otherwise. Control variables are taken from prior executive compensation studies and defined in the 
Appendix. Regressions estimated based on equation (1) include industry and year fixed effects, and standard errors are clustered by firm.

The results are presented in Table 2 - 3. We find that executives in fraud firms are paid a significantly higher total compensation and that approximately two-thirds of this difference come from higher option grants (Total Comp and Option are both significant at the 0.01 level). Fraud firm executives are paid approximately $\$ 918,000$ more per year and $\$ 592,000$ more in option grants. Fraud firm executives also receive significantly higher bonuses (significant at the 0.05 level) of approximately $\$ 230,000$. While options and bonuses are both forms of incentive compensation, we find that the increase in options is approximately 2.5 times that of bonuses in fraud firms.

Not surprisingly, we find that larger firms pay greater total compensation and also more of each compensation component (all significant at the 0.01 level). Firms with higher returns pay lower compensation (holds for all compensation component) while firms with more volatile stock prices pay higher compensation (holds for all compensation component). The results on stock price volatility could indicate that executives are paid a premium for working at risky firms, but option values also strictly increase in volatility, so the significantly larger difference in option values has more than one component. We find that the value of option grants and total compensation decreases over tenure while salary and bonus increase. Lastly, CEOs are paid more than nonCEOs.

[Insert Table 2 - 3 here]

It is possible that something changes in fraud firms' profiles in the years leading up to fraud that affects compensation. Perhaps the board of directors sets a new direction for the firm and 
begins to prefer different pay packages, new executives enter the firm with different pay preferences, or current executives increase their bargaining power and negotiate pay changes for that reason. Prior research has not considered whether differences in equity incentives begin just before the fraud or are a long-standing aspect of the firm.

To analyze the timeline of compensation differences in firms, we re-estimate equation (1) for each year of an executive's tenure to consider trends in pay. Further, we distinguish between CEO and non-CEO executives as pay could vary temporally across the two groups, and we estimate equation (1) separately for each executive group. Results for CEOs are presented in Table 2 - 4. The results are largely consistent with those in Table $2-3$, but they do not suggest that something happens over time within firms. Instead, they suggest that the firms systematically have different pay practices beginning in year 1 of a CEO's tenure. CEOs at fraud firms have greater option grants in each of the first 10 years of their tenure, significantly so in the first 8 years. Fraud firm CEOs also earn higher bonuses and salaries in the first 7 years of their tenure, but the combined amount of salary and bonus is less than the value of option grants in all of those years. Fraud firm CEOs earn a significantly higher restricted stock in years 2 through 5 of their tenure, but after that, restricted stock grants are insignificant and have a negative coefficient in some years. Bonus and salary differences are relatively constant over the first 6 and 8 years of CEO tenure while differences in option grants start at their highest point in year 1 of tenure and gradually decline (with a large upward spike in year 8). Option differences appear to drive over 50 percent of the difference in total compensation in 9 of 10 years of tenure.

[Insert Table 2 - 4 here]

The results for non-CEOs are presented in Table $2-5$. Non-CEOs in fraud firms receive greater option grants in all the first 10 years of their tenures. They also receive higher bonuses during the 
first 6 years of their tenure and higher salaries and restricted stock in 5 of the first 6 years of their tenures. The evidence suggests that fraud firms pay their non-CEOs greater total compensation across all components in the early years of their tenure and persist in awarding more valuable option grants throughout the first 10 years of tenure. The amount of the option grants is greater than the sum of bonuses, salary, and restricted stock in 9 of 10 years, and it is slightly lower in year 1. One key difference between CEOs and non-CEOs is that the value of option grants rises steadily over non-CEOs' tenure, and then it begins to decline near the end of the first 10 years, instead of starting high and decreasing over time. A potential explanation is that fewer non-CEOs stay in their roles for 6 or more years, and it may require greater compensation to keep them from leaving and potentially taking a CEO position elsewhere.

These results strongly suggest that executives at fraud firms receive greater compensation, largely through option grants, and that persists across an executive's tenure at the firm. This holds regardless of when fraud occurs during an individual executive's tenure and even when including executives who leave the firm years before the fraud begins. Thus, these differences do not seem to be affected by the years just before the fraud when the firm may be in decline. Still, the results do not tell us if there is variance in compensation preferences within the firm among executives who become involved in the fraud and those who do not. We examine compensation differences among executives in fraud firms next.

[Insert Table 2 - 5 here]

\subsection{Compensation differences within fraud firms}

To examine Hypothesis 2 and test whether there are compensation differences within fraud firms among executives who perpetrate fraud and those who do not, we estimate the following equation: 


$$
\text { Comp }_{i, t}=\beta_{1} \text { Named }_{i, t}+\beta_{2} \text { Tenure }_{i, t}+\text { Firm FE }+ \text { Year FE }+\varepsilon_{i, t}
$$

Where Comp is either: Total Comp, Bonus, Salary, Rstock, or Option. Named is an indicator variable set to 1 if the executive was named by the SEC as a perpetrator of the fraud, and 0 otherwise. As this equation includes firm and year fixed effects and examines multiple executives in the same firm in the same year, we do not include the control variables modeled in equation (1).

The results are presented in Table $2-6$. Within fraud firms, we find that named executives do receive greater total compensation but that over $90 \%$ of this compensation is in the form of option grants, more specifically $\$ 933,000$ total compensation and $\$ 918,000$ in option grants. We also find that named executives have higher average salaries, but the difference is just $\$ 35,000$. Similar to our cross-sectional results presented in Table 2 - 3, we find that bonuses and salaries increase with tenure. However, in contrast, we observe positive coefficients for total compensation, restricted stock, and options, though the latter two are not statistically significant. The results suggest that there is a variation within fraud firms in option grants among named and non-named executives.

$$
\text { [Insert Table } 2 \text { - } 6 \text { here] }
$$

We next consider whether there are patterns through executives' tenure within fraud firms. The results are presented in Table $2-7^{10}$. The results show a considerable variation through tenure years. Though significantly higher overall, named executives do not have significantly higher salaries in any one year of tenure, though the coefficient is positive in all 8 years. Named executives do not receive significantly higher or lower bonuses or restricted stock in any one year either and both have negative coefficients in 6 of 8 years. The association between perpetrating

\footnotetext{
${ }^{10} \mathrm{We}$ examine only the first 8 years of tenure as we have few observations and a little intra-firm variation to exploit after that point in time.
} 
fraud and option grants appears driven mostly by the latter years of executive tenure. Named executives receive significantly higher option grants in years 5,6 , and 7 of their tenure at the 0.05 level. It is important to mention that the coefficient in year 8 is economically large but statistically insignificant. Option grants are also significantly higher in year 2 of tenure but are negative in years 1,3 , and 4 , though economically small in years 3 and 4 . Total compensation is only significantly higher in the years in which option grants are significantly higher.

\section{[Insert Table 2 - 7 here]}

The results in Table $2-6$ and $2-7$ suggest that named executives do have idiosyncratic compensation preferences, but the differences are generally only significant during the latter years of an executive's tenure. Further, the differences are only present for option grants, which may be related to why some executives are more willing to take risks and misreport. It is also possible that many executives do not have the power to negotiate contracts tailored to their preferences until they have several years of tenure at the firm. Compensation differences within fraud firm are certainly less stable than they are between fraud and non-fraud firms, but the results do suggest the possibility of an executive effect. Next, we examine potential executive-related effect on the probability to misreport.

\subsection{Differences in diversification and portfolio management}

We estimate the following equation to examine Hypothesis 3 and test whether differences in how executives, within fraud firms, manage their equity portfolios are associated with misreporting risk. 


$$
\begin{aligned}
\text { Portfolio }_{i, j, t}= & \beta_{1} \text { Named }_{i, j, t}+\beta_{2} \text { Size }_{j, t}+\beta_{3} \text { MTB }_{j, t}+\beta_{4} \text { Debt }_{j, t}+\beta_{5} \text { Return }_{j, t}+ \\
& \beta_{6} \text { Volatility }_{j, t}+\beta_{7} \text { Geographic }_{j, t}+\beta_{8} \text { Segment }_{j, t}+\beta_{9} \text { Tenure }_{i, j, t}+ \\
& \beta_{10} \text { CEO }_{i, j, t}+\text { Firm FE }+ \text { Year FE }+\varepsilon_{i, t}
\end{aligned}
$$

Where Portfolio is either: Shares Sold, Pct Shares Sold, Pct Options, Firm Wealth, or Ch Firm Wealth. Shares Sold is the number of shares the executive sold during the year. Pct Shares Sold is the percentage of total shares held the executive sold during the year. Pct Option is the percentage of equity shares held by the executive that is stock options. Firm Wealth is the percentage of the executive's total wealth held in firm equity. Total wealth is the sum of firm-based wealth following Coles, Daniel and Naveen (2013) and non-firm based wealth following Dittmann and Maug (2007). Ch Firm Wealth is the change in Firm Wealth. Named is an indicator variable set to 1 if the executive is named by the SEC as a perpetrator of the fraud, and 0 otherwise. As there are no established models in the literature related to within firm portfolio management choices, we include the same control variables as those included in equation (1) discussed in section 4.1. These variables are defined in the Appendix. We also include firm and year fixed effects in the model to examine differences in the portfolio management among named and non-named executives in the same firm.

Equation (3) is estimated for all executive tenure years after year 5. In the early years of tenure, executives are unlikely to have accumulated equity that they can contractually divest, and differences in equity holdings of executives hired internally versus externally could also more strongly explain portfolio choices in the first years of tenure. Most of the executives who are granted stock options as part of their compensation will not be able to exercise those options until 3 or more years after they are granted. We choose to examine differences in portfolio management after the fifth year of tenure to be consistent with the prior literature. For instance, Malmendier 
and Tate (2005) estimate executive overconfidence by examining differences in the executive portfolio management over years 6-10 of their tenure compared to years $1-5^{11}$.

The results are presented in Table $2-8$ and provide strong evidence that executives who perpetrate fraud manage their firm-based equity in significantly different ways than do non-named executives within the same firm. First, named executives sell fewer shares of common stock each year and a smaller percentage of their stock holdings (both significant at the 0.05 level). The coefficient of -0.103 on Named, when examining the percentage of shares sold, indicates that named executives sell 10 percent less of their common equity holdings per year than do non-named executives. Not surprisingly, we also find that executives sell fewer shares and a lower percentage of their holdings when stock prices are high as the coefficient on Return is negative and significant in both models. The results suggest that one reason why the perpetrators of fraud have strong equity incentives is because they hold a significantly larger percentage of previously accumulated equity.

Second, named executives hold approximately 11 percent more of their total firm-level equity in the form of stock options (significant at the 0.01 level) compared to non-named executives in the same firm. As noted in Armstrong et al. (2013), stock options provide different risk taking incentives than do common shares. Most firms do not have contractual requirements regarding what percentage of equity must be held in options (that differ across executives in that firm), so this difference appears consistent with named executives having idiosyncratic preferences in how they manage their accumulated equity compensation.

\footnotetext{
${ }^{11}$ Our results are highly similar in terms of both statistical and economic significance if we consider years after the fourth or sixth year of tenure, and they are available upon request.
} 
Finally, we find that firm-based wealth is a higher percentage of total wealth for named executives (significant at the 0.01 level) than for non-named executives and that the year-on-year change in the fraction of total wealth that is firm-based is higher for named executives as well (significant at the 0.05 level). We find that 9 percent more of the named executive's total wealth is associated with their firm's equity. This lack of diversification creates relatively stronger incentives for misreporting that are independent of annual compensation differences. The fraction of wealth held in employer equities is increasing during tenure at a higher rate for named executives as well. For executives who stay with a firm for a long period of time, the differences in equity incentives due to portfolio management choices will become quite large.

In sum, we find that named executives sell a lower percentage of their common stock holdings, hold a higher percentage of their firm-based equity in stock options, and have a larger percentage of their total wealth in their employer's equities. These differences exist across executives in the same firm who operate in a similar contracting environment, suggesting that firm-level compensation preferences are not the cause of these differences. While idiosyncratic compensation preferences can be associated with the number of shares executives sell and the ratio of options to common shares, such preferences are unlikely to explain the percentage of stock an executive sells or the fraction of total wealth tied to employer equities. The evidence suggests that how executives manage their portfolios is strongly associated with the firm's financial reporting risk.

[Insert Table 2 - 8 here]

\subsection{CONCLUSION}

The motivation of this study consists of prior empirical studies documenting a positive association between incentives from an executive's firm-based wealth and financial misreporting. We consider three explanations for this documented positive association between equity-based 
compensation and financial misreporting. The first is that future misreporting firms unilaterally choose or need to offer higher equity compensation to prospective hires. These misreporting firms may offer higher equity incentives due to specific strategies and preferences for risk or due to desire to attract talent. To test this explanation, we examine compensation differences between misreporting and control firms for all executives during their entire tenure with the respective firm. The second explanation, for the positive association between equity-based compensation and financial misreporting, is that executives, who perpetrate fraud, have different compensation preferences and negotiate pay packages with higher levels or ratios of equity compensation. Under this explanation, we examine compensation differences between executives who are named and executives who are not named as fraud perpetrators by the SEC. The third explanation is that regardless of across or within firm pay differences, executives who perpetrate reporting fraud have strong equity incentives because of how they manage their portfolio over time. If certain executives rarely divest themselves of equity-based compensation, then over time the value of their firmbased wealth and any incentives it creates will grow regardless of firm or executive specific compensation differences. Therefore, we examine whether differences in how executives, within fraud firms, manage their equity portfolios are associated with the misreporting risk.

In sum, we find at least some evidence for all three distinct explanations, that could lead to a positive association between equity incentives and misreporting. First, misreporting firms prefer to pay their executives differently; second, executives who perpetrate fraud negotiate contracts with a higher level of option grants; and third, executives who perpetrate fraud diversify themselves less and manage their portfolios differently from other executives. The results suggest that actions by both the firm and the executives contribute to an environment where misreporting 
is more likely, and that pay practices by themselves may not significantly increase the fraud risk level if certain portfolio practices by executives are absent.

These findings make important contribution to the accounting research literature by examining potential explanations for documented compensation differences between fraud and control firms. Unlike prior literature that examined compensation differences only in the last fraud year, we examine compensation differences over entire executive tenure, and also for each tenure year separately. Further, the results help practitioners by suggesting that both firm-level and executive-level compensation preferences combined with the idiosyncratic portfolio management all contribute jointly to an increased reporting risk. One possible channel through which the reporting risk could be reduced is to encourage executives to diversify their portfolios throughout their tenure as their firm-based wealth increases from accumulated compensation over time.

These conclusions should be interpreted in light of various limitations. We assume the SEC accurately identifies perpetrators in fraud cases. The SEC exercises extreme diligence in naming executives in their enforcements, however, due to limited resources there exists the possibility that the SEC misses some of the perpetrators. Also, we only distinguish between CEO and non-CEO executives, which include among other $\mathrm{CFO}, \mathrm{CAO}, \mathrm{COO}$ etc. The extent to which our findings generalized to each of the non-CEO executives is limited. 


\section{References}

Armstrong, C. S., J. E. Core, and W. R. Guay. 2015. Why do CEOs hold so much equity? SSRN.

Armstrong, C. S., D. F. Larcker, G. Ormazabal, and D. J. Taylor. 2013. The relation between equity incentives and misreporting: The role of risk-taking incentives. Journal of Financial Economics 109 (2):327-350.

Beasley, M. S., J. V. Carcello, D. R. Hermanson, and T. L. Neal. 2010. Fraudulent Financial Reporting 1998 - 2007. Committee of Sponsoring Organizations of the Treadway Commission 2

Beneish, M. D., C. D. Marshall, and J. Yang. 2017. Explaining CEO retention in misreporting firms. Journal of Financial Economics 123 (3):512-535.

Bergstresser, D., and T. Philippon. 2006. CEO incentives and earnings management. Journal of Financial Economics 80 (3):511-529.

Brick, I. E., O. Palmon, and J. K. Wald. 2006. CEO compensation, director compensation, and firm performance: Evidence of cronyism? Journal of Corporate Finance 12 (3):403-423.

Burns, N., and S. Kedia. 2006. The impact of performance-based compensation on misreporting. Journal of Financial Economics 79 (1):35-67.

Bushman, R. M., R. J. Indjejikian, and A. Smith. 1996. CEO compensation: The role of individual performance evaluation. Journal of Accounting and Economics 21:161 - 193.

Cadman, B., M. E. Carter, and S. Hillegeist. 2010. The incentives of compensation consultants and CEO pay. Journal of Accounting and Economics 49 (3):263-280.

Cheng, Q., and D. B. Farber. 2008. Earnings restatement, chnges in CEO compenstion, and firm performance. The Accounting Review 83 (5):1217 - 1250.

Cheng, Q., and T. D. Warfield. 2005. Equity inventives and earnings management. The Accounting Review 80 (2):2005.

Cohen, L., C. Malloy, and L. Pomorski. 2012. Decoding inside information. The Journal of Finance 67 (3).

Coles, J. L., N. D. Daniel, and L. Naveen. 2013. Calculation of compensation incentives and firm-related wealth using ExecuComp; Data, Program and Explanation. SSRN.

Davidson, R. H. 2018. Executive equity compensation and financial statement fraud. SSRN.

Denis, D. J., P. Hanouna, and A. Sarin. 2006. Is there a dark side to incentive compensation? Journal of Corporate Finance 12 (3):467-488.

Dittmann, I., and E. Maug. 2007. Lower salaries and no options? On the optimal structure of executive pay. The Journal of Finance 62 (1):303 - 343.

Efendi, J., A. Srivastava, and E. P. Swanson. 2007. Why do corporate managers misstate financial statements? The role of option compensation and other factors. Journal of Financial Economics 85 (3):667-708.

Erickson, M., M. Hanlon, and E. L. Maydew. 2006. Is There a Link between Executive Equity Incentives and Accounting Fraud? Journal of Accounting Research 44 (1):113-143.

Feng, M., W. Ge, S. Luo, and T. Shevlin. 2011. Why do CFOs become involved in material accounting manipulations? Journal of Accounting and Economics 51 (1-2):21-36.

Fracassi, C., and G. Tate. 2012. External networking and internal firm governance. The Journal of Finance 67 (1):153 - 194.

Frydman, C., and D. Jenter. 2010. CEO compensation. Annual Review of Financial Economics 2 (1):75102.

Goergen, M., and L. Renneboog. 2011. Managerial compensation. Journal of Corporate Finance 17 (4):1068-1077.

Hall, B. J., and J. B. Liebman. 1998. Are CEOs really paid like bureaucrats? The Quarterly Journal of Economics 113 (3):653-691.

Harris, J., and P. Bromiley. 2007. Incentives to Cheat: The Influence of Executive Compensation and Firm Performance on Financial Misrepresentation. Organization Science 18 (3):350-367.

Hwang, B.-H., and S. Kim. 2009. It pays to have friends. Journal of Financial Economics 93 (1):138-158. 
Jensen, M. C. 2005. Agency costs of overvalued equity. Financial Management 34:5-19.

Jensen, M. C., and W. H. Meckling. 1976. Theory of the Firm: Managerial behavior, agency costs and ownership structure. Journal of Financial Economics 3:305 - 360.

Jiang, J., K. R. Petroni, and I. Yanyan Wang. 2010. CFOs and CEOs: Who have the most influence on earnings management? Journal of Financial Economics 96 (3):513-526.

Kallunki, J., J.-P. Kallunki, H. Nilsson, and M. Puhakka. 2018. Do an insider's wealth and income matter in the decision to engage in insider trading? Journal of Financial Economics 130 (1):135-165.

Karpoff, J. M., A. Koester, D. S. Lee, and G. S. Martin. 2017. Proxies and Databases in Financial Misconduct Research. The Accounting Review 92 (6):129-163.

Kedia, S., and T. Philippon. 2009. The Economics of Fraudulent Accounting. Review of Financial Studies $22(6): 2169-2199$.

Malmendier, U., and G. Tate. 2005. CEO overconfidence and corporate investment. The Journal of Finance 60 (6).

Murphy, K. J. 2013. Executive compensation: Where we are, and how we got there. Handbook of the Economics of Finance. 2:211 - 356.

Murphy, K. J., and T. Sandino. 2010. Executive pay and "independent" compensation consultants. Journal of Accounting and Economics 49 (3):247-262.

RTTN, A.-. 2016. Report to the Nations on Occupational Fraud and Abuse. Global Fraud Studies. 


\section{Appendix}

Variable definitions and data sources

\begin{tabular}{|c|c|c|}
\hline Variable & Definition & Source \\
\hline Fraud & An indicator variable set to 1 if the firm is a fraud firm, and 0 otherwise & SEC AAERs \\
\hline Named & $\begin{array}{l}\text { An indicator variable set to } 1 \text { if the SEC named the executive as a perpetrator of } \\
\text { fraud, and } 0 \text { otherwise }\end{array}$ & SEC AAERs \\
\hline Total Comp & Total value of all forms of compensation for the current year. & Execucomp/SEC \\
\hline Bonus & Total value of cash bonuses received during the year. & Execucomp/SEC \\
\hline Salary & Total value of base salary received during the year. & Execucomp/SEC \\
\hline Rstock & Total value of restricted stock awarded during the year. & Execucomp/SEC \\
\hline Option & Total value of stock options awarded during the year. & Execucomp/SEC \\
\hline Size & The natural logarithm of the firm's market capitalization. & Compustat \\
\hline МТВ & The ratio of the firm's market value of equity to book value. & Compustat \\
\hline Debt & The ratio of the firm's long-term debt total assets. & Compustat \\
\hline Return & The firm's market adjusted annual stock return. & CRSP \\
\hline Volatility & The standard deviation of the firm's past 12 monthly stock returns. & CRSP \\
\hline Geographic & The number of geographic segments the firm operates in. & Compustat \\
\hline Segment & The number of business segments the firm operates in. & Compustat \\
\hline Tenure & $\begin{array}{l}\text { The tenure of the executive in the current role (for CEOs) or as a top } 5 \text { paid } \\
\text { executive (non-CEOs). }\end{array}$ & Execucomp/SEC \\
\hline CEO & An indicator variable set to 1 if the executive is the firm's CEO, and 0 otherwise. & Execucomp/SEC \\
\hline Shares Sold & The number of shares the executive sold during the year. & Execucomp/SEC \\
\hline Pct Shares Sold & The percentage of total shares held the executive sold during the year. & Execucomp/SEC \\
\hline Pct Option & The percentage of equity shares held by the executive that is stock options. & Execucomp/SEC \\
\hline Firm Wealth & $\begin{array}{l}\text { The percentage of the executive's total wealth held in firm equity; total wealth is } \\
\text { the sum of firm based wealth following Coles et al. (2013) and non-firm based } \\
\text { wealth following Dittman and Maug (2007). }\end{array}$ & Execucomp/SEC \\
\hline Ch Firm Wealth & The change Firm Wealth. & Execucomp/SEC \\
\hline
\end{tabular}


Figure 2 - 1: Cumulative Compensation for Fraud and Non-Fraud Firm CEOs

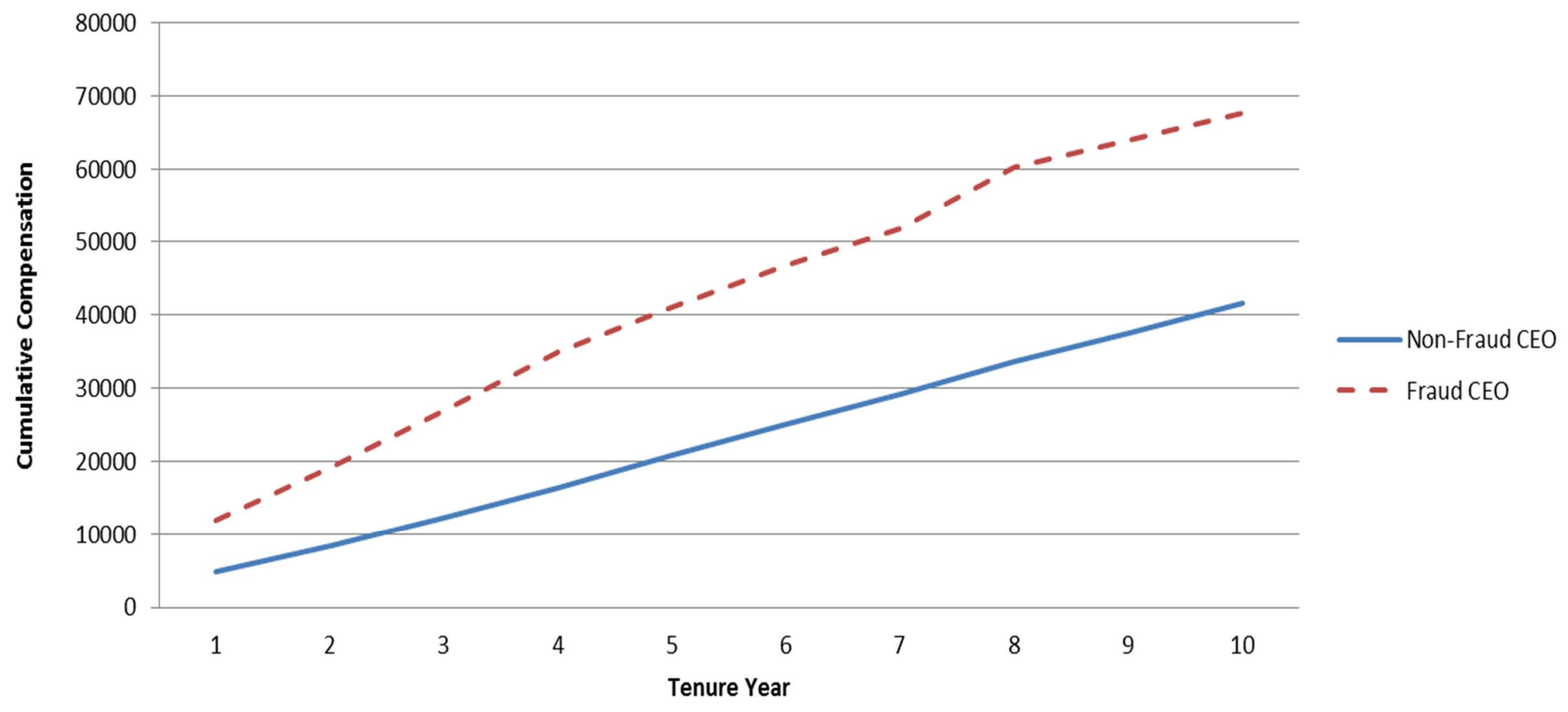


Figure 2 - 2: Cumulative Compensation for Fraud and Non-Fraud Firm Non-CEOs

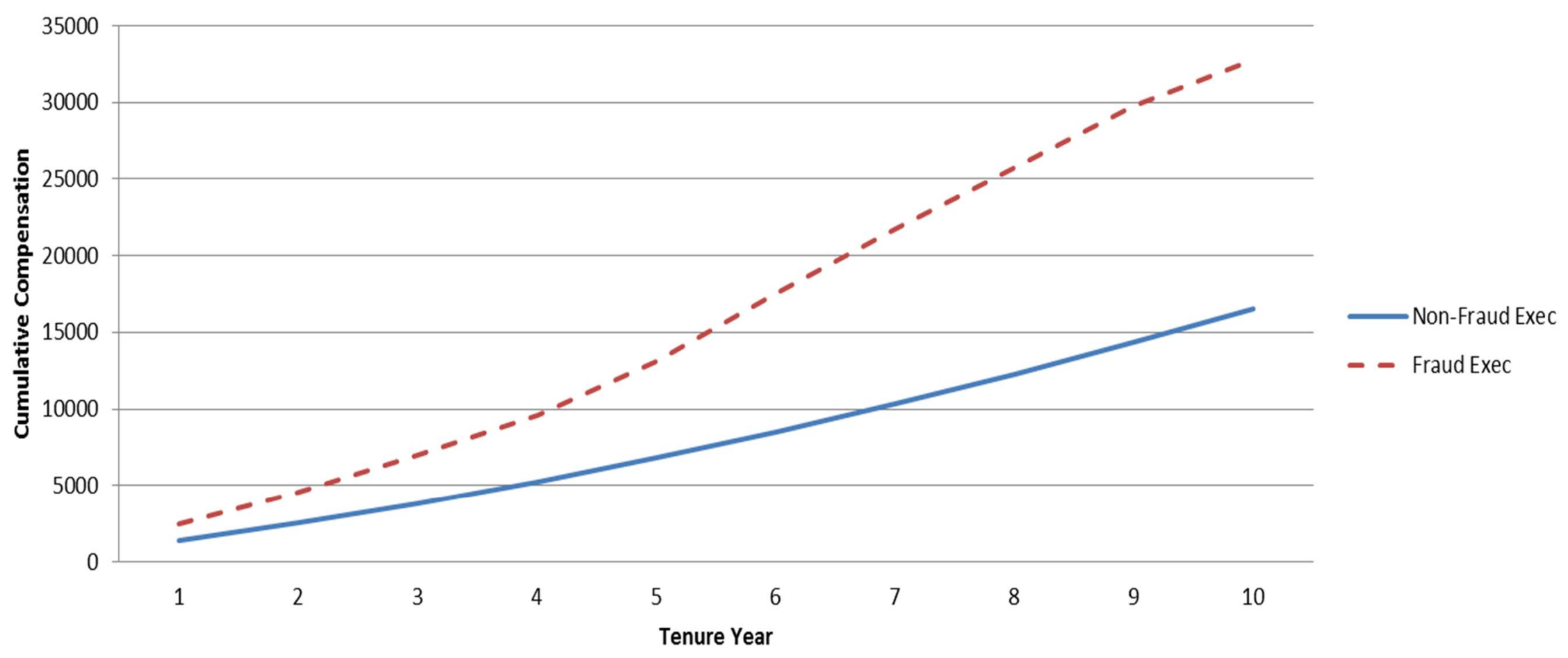




\section{Table 2 - 1: Sample Composition}

This table provides summary statistics regarding the number of AAER fraud firms, executives at AAER firms, and named executives at AAER firms with compensation data available.

\begin{tabular}{lc}
\hline AAERs (issued between 1/1/1986 - 12/12/2017) & 3,815 \\
AAER firms charged with financial statement manipulation with compensation data available prior to \\
the manipulation period
\end{tabular}


Table 2 - 2: Summary Statistics - Executive-Level Variables

This table reports the mean, median and standard deviation of executive-level variables for fraud and non-fraud firms and for CEOs and non-CEOs. Variable are defined in the Appendix.**, $* *$, and $*$ represent statistical significance at the $0.01,0.05$, and 0.10 levels respectively.

\begin{tabular}{l|ccc|ccc}
\hline & \multicolumn{3}{|c}{ Fraud Firm CEOs } & \multicolumn{3}{c}{ Non-Fraud Firm CEOs } \\
\cline { 2 - 7 } & Mean & Median & Std. Deviation & Mean & Median & Std. Deviation \\
\hline Total Comp & $4,644 * * *$ & $2,543 * * *$ & 5,257 & 3,605 & 2,013 & 4,123 \\
Bonus & $685 * * *$ & $365 * * *$ & 825 & 412 & 150 & 631 \\
Salary & 609 & 575 & 324 & 583 & 540 & 294 \\
Rstock & 282 & 0 & 783 & 245 & 0 & 675 \\
Option & $1,871 * * *$ & $603 * * *$ & 2,761 & 1,257 & 341 & 2,144 \\
Tenure & $8.44 * * *$ & $7.00 * * *$ & 6.58 & 7.78 & 6.00 & 6.31 \\
\hline
\end{tabular}

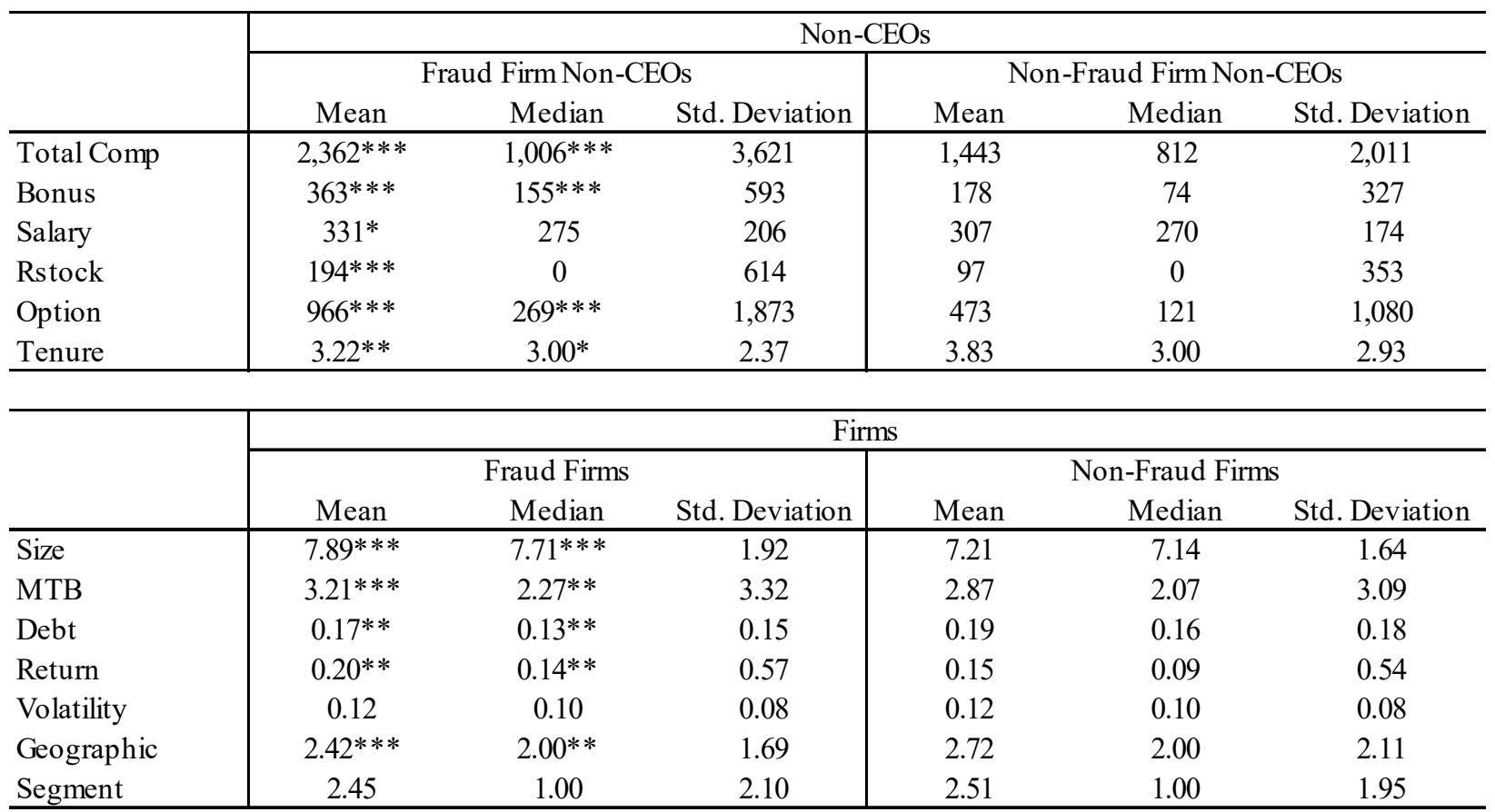




\section{Table 2 - 3: Executive Compensation in Fraud and Non-Fraud Firms}

This table reports results from OLS regression estimates of equation (1) comparing components of executive compensation across fraud and non-fraud firms. Total Comp is the total value of all forms of compensation for the current year; Bonus is the value of cash bonuses received during the year; Salary is the value of base salary received during the year; Rstock is the value of restricted stock awarded during the year; Option is the value of stock options awarded during the year. Fraud is an indicator variable set to 1 if the firm is a fraud firm, and 0 otherwise. Control variables are are defined in the Appendix. T-statistics are clustered at the firm level. ***, **, and * represent statistical significance at the $0.01,0.05$, and 0.10 levels respectively.

\begin{tabular}{|c|c|c|c|c|c|}
\hline & Total Comp & Bonus & Salary & Rstock & Option \\
\hline Fraud & $\begin{array}{c}918.64 * * * \\
(2.76)\end{array}$ & $\begin{array}{c}203.70^{* *} \\
(2.15)\end{array}$ & $\begin{array}{l}10.93 \\
(0.96)\end{array}$ & $\begin{array}{l}91.39 \\
(1.36)\end{array}$ & $\begin{array}{c}592.21 * * * \\
(2.66)\end{array}$ \\
\hline Size & $\begin{array}{c}923.03 * * * \\
(25.67)\end{array}$ & $\begin{array}{c}107.35 * * * \\
(15.36)\end{array}$ & $\begin{array}{c}62.85 * * * \\
(34.00)\end{array}$ & $\begin{array}{c}103.50 * * * \\
(7.25)\end{array}$ & $\begin{array}{c}432.83 * * * \\
(18.08)\end{array}$ \\
\hline MTB & $\begin{array}{c}-0.05 \\
(-0.39)\end{array}$ & $\begin{array}{c}-0.02 \\
(-1.05)\end{array}$ & $\begin{array}{l}-0.03 * \\
(-1.81)\end{array}$ & $\begin{array}{c}-0.05^{* *} \\
(-2.08)\end{array}$ & $\begin{array}{c}0.06 \\
(0.88)\end{array}$ \\
\hline Debt & $\begin{array}{c}258.12 \\
(1.54)\end{array}$ & $\begin{array}{l}-18.60 \\
(-0.67)\end{array}$ & $\begin{array}{l}65.01 * * * \\
(5.72)\end{array}$ & $\begin{array}{c}120.41^{*} \\
(1.95)\end{array}$ & $\begin{array}{c}-116.06 \\
(-0.89)\end{array}$ \\
\hline Return & $\begin{array}{c}-472.71 * * * \\
(-7.59)\end{array}$ & $\begin{array}{c}-39.14 * * * \\
(-6.18)\end{array}$ & $\begin{array}{c}-22.15^{* * *} \\
(-8.19)\end{array}$ & $\begin{array}{c}-34.09 * * * \\
(-5.21)\end{array}$ & $\begin{array}{c}-299.53 * * * \\
(-7.24)\end{array}$ \\
\hline Volatility & $\begin{array}{c}2,840.58^{* * *} \\
(5.12)\end{array}$ & $\begin{array}{c}224.10 * * * \\
(4.57)\end{array}$ & $\begin{array}{c}116.98 * * * \\
(6.30)\end{array}$ & $\begin{array}{c}191.48 * * * \\
(4.66)\end{array}$ & $\begin{array}{c}1,840.44 * * * \\
(4.77)\end{array}$ \\
\hline Geographic & $\begin{array}{c}38.82^{* *} \\
(2.43)\end{array}$ & $\begin{array}{c}0.42 \\
(0.16)\end{array}$ & $\begin{array}{c}2.44 * * * \\
(2.64)\end{array}$ & $\begin{array}{c}15.35^{* *} \\
(2.06)\end{array}$ & $\begin{array}{l}11.79 \\
(1.16)\end{array}$ \\
\hline Segment & $\begin{array}{c}0.45 \\
(0.02)\end{array}$ & $\begin{array}{c}5.35 \\
(1.41)\end{array}$ & $\begin{array}{c}8.73 * * * \\
(4.92)\end{array}$ & $\begin{array}{l}-5.50 \\
(-0.72)\end{array}$ & $\begin{array}{l}-21.73 \\
(-1.43)\end{array}$ \\
\hline Tenure & $\begin{array}{c}-20.53 * * * \\
(-2.65)\end{array}$ & $\begin{array}{c}6.73 * * * \\
(3.19)\end{array}$ & $\begin{array}{c}5.82 * * * \\
(12.18)\end{array}$ & $\begin{array}{c}-2.78 \\
(-0.48)\end{array}$ & $\begin{array}{c}-26.10 * * * \\
(-7.16)\end{array}$ \\
\hline CEO & $\begin{array}{c}2,673.82 * * * \\
(33.08)\end{array}$ & $\begin{array}{c}304.57 * * * \\
(23.59)\end{array}$ & $\begin{array}{c}259.05 * * * \\
(64.19)\end{array}$ & $\begin{array}{c}278.08 * * * \\
(17.10)\end{array}$ & $\begin{array}{c}1,258.97 * * * \\
(21.02)\end{array}$ \\
\hline $\begin{array}{l}\text { Industry Fixed Effects } \\
\text { Year Fixed Effects }\end{array}$ & $\begin{array}{l}\text { Yes } \\
\text { Yes }\end{array}$ & $\begin{array}{l}\text { Yes } \\
\text { Yes }\end{array}$ & $\begin{array}{l}\text { Yes } \\
\text { Yes }\end{array}$ & $\begin{array}{l}\text { Yes } \\
\text { Yes }\end{array}$ & $\begin{array}{l}\text { Yes } \\
\text { Yes }\end{array}$ \\
\hline $\begin{array}{l}\text { Observations } \\
\text { Adjusted R-Squared }\end{array}$ & $\begin{array}{c}168,674 \\
0.16\end{array}$ & $\begin{array}{c}194,489 \\
0.12\end{array}$ & $\begin{array}{c}194,489 \\
0.44\end{array}$ & $\begin{array}{c}144,705 \\
0.01\end{array}$ & $\begin{array}{c}168,788 \\
0.07\end{array}$ \\
\hline
\end{tabular}




\section{Table 2 - 4: CEO Compensation by Tenure Year in Fraud and Non-Fraud Firms}

This table reports results from OLS regression estimates of equation (1) comparing components of executive compensation across fraud and non-fraud firms during each year of tenure for CEOs. Total Comp is the total value of all forms of compensation for the current year; Bonus is the value of cash bonuses received during the year; Salary is the value of base salary received during the year; Rstock is the value of restricted stock awarded during the year; Option is the value of stock options awarded during the year. Fraud is an indicator variable set to 1 if the firm is a fraud firm, and 0 otherwise. Control variables are are defined in the Appendix. T-statistics are clustered at the firm level. $* * * * *$, and $*$ represent statistical significance at the $0.01,0.05$, and 0.10 levels respectively.

\begin{tabular}{|c|c|c|c|c|c|c|}
\hline Tenure Year & Total Comp & Bonus & Salary & Rstock & Option & Observations \\
\hline & \multicolumn{5}{|c|}{$\begin{array}{l}\text { Coefficient on dichotomous variable Fraud } \\
\text { (T-Statistic) }\end{array}$} & \\
\hline 1 & $\begin{array}{l}7,240 * * * \\
(5.03)\end{array}$ & $\begin{array}{c}558 * * * \\
(5.38)\end{array}$ & $\begin{array}{c}179 * * * \\
(6.15)\end{array}$ & $\begin{array}{c}93 \\
(0.38)\end{array}$ & $\begin{array}{l}6,191 * * * \\
\quad(4.66)\end{array}$ & 3,860 \\
\hline 2 & $\begin{array}{l}3,927 * * * \\
(6.73)\end{array}$ & $\begin{array}{c}639 * * * \\
(5.10)\end{array}$ & $\begin{array}{c}162 * * * \\
(4.97)\end{array}$ & $\begin{array}{l}420 * * \\
(2.28)\end{array}$ & $\begin{array}{l}2,024 * * * \\
\quad(5.15)\end{array}$ & 3,779 \\
\hline 3 & $\begin{array}{l}4,456 * * * \\
(5.49)\end{array}$ & $\begin{array}{c}1056 * * * \\
(10.58)\end{array}$ & $\begin{array}{c}143 * * * \\
(4.11)\end{array}$ & $\begin{array}{c}601 * * * \\
(3.46)\end{array}$ & $\begin{array}{l}2,302 * * * \\
\quad(3.48)\end{array}$ & 3,419 \\
\hline 4 & $\begin{array}{l}4,227 * * * \\
(3.67)\end{array}$ & $\begin{array}{c}765 * * * \\
(7.18)\end{array}$ & $\begin{array}{c}126 * * * \\
(3.31)\end{array}$ & $\begin{array}{l}414^{*} \\
(1.70)\end{array}$ & $\begin{array}{c}2,507 * * \\
(2.42)\end{array}$ & 3,061 \\
\hline 5 & $\begin{array}{l}2,574 * * * \\
(2.96)\end{array}$ & $\begin{array}{c}399 * * * \\
(3.22)\end{array}$ & $\begin{array}{l}100 * * \\
(2.55)\end{array}$ & $\begin{array}{c}510 * * * \\
(2.74)\end{array}$ & $\begin{array}{c}1,522 * * \\
(2.25)\end{array}$ & 2,742 \\
\hline 6 & $\begin{array}{c}2,215 * * * \\
(2.61)\end{array}$ & $\begin{array}{c}698 * * * \\
(5.25)\end{array}$ & $\begin{array}{l}101 * * \\
(2.52)\end{array}$ & $\begin{array}{c}-139 \\
(-0.77)\end{array}$ & $\begin{array}{c}1,153 * * \\
(2.23)\end{array}$ & 2,417 \\
\hline 7 & $\begin{array}{c}1,672 * * \\
(2.09)\end{array}$ & $\begin{array}{c}281^{*} \\
(1.90)\end{array}$ & $\begin{array}{c}136 * * * \\
(3.00)\end{array}$ & $\begin{array}{c}173 \\
(0.93)\end{array}$ & $\begin{array}{c}693 * \\
(1.70)\end{array}$ & 2,090 \\
\hline 8 & $\begin{array}{c}3,376 * * \\
(2.40)\end{array}$ & $\begin{array}{c}40 \\
(1.03)\end{array}$ & $\begin{array}{l}97 * * \\
(2.00)\end{array}$ & $\begin{array}{c}-323 \\
(-1.25)\end{array}$ & $\begin{array}{c}2,797 * * \\
(2.31)\end{array}$ & 1,834 \\
\hline 9 & $\begin{array}{c}161 \\
(0.13)\end{array}$ & $\begin{array}{c}38 \\
(0.21)\end{array}$ & $\begin{array}{c}28 \\
(0.52)\end{array}$ & $\begin{array}{c}19 \\
(0.11)\end{array}$ & $\begin{array}{c}387 \\
(0.35)\end{array}$ & 1,592 \\
\hline 10 & $\begin{array}{c}78 \\
(0.09) \\
\end{array}$ & $\begin{array}{c}-56 \\
(-0.37) \\
\end{array}$ & $\begin{array}{c}34 \\
(0.56) \\
\end{array}$ & $\begin{array}{c}62 \\
(0.27) \\
\end{array}$ & $\begin{array}{c}313 \\
(0.76) \\
\end{array}$ & 1,378 \\
\hline $\begin{array}{l}\text { Controls } \\
\text { Industry Fixed Effects } \\
\text { Year Fixed Effects }\end{array}$ & $\begin{array}{l}\text { Yes } \\
\text { Yes } \\
\text { Yes }\end{array}$ & $\begin{array}{l}\text { Yes } \\
\text { Yes } \\
\text { Yes }\end{array}$ & $\begin{array}{l}\text { Yes } \\
\text { Yes } \\
\text { Yes }\end{array}$ & $\begin{array}{l}\text { Yes } \\
\text { Yes } \\
\text { Yes }\end{array}$ & $\begin{array}{l}\text { Yes } \\
\text { Yes } \\
\text { Yes }\end{array}$ & \\
\hline
\end{tabular}




\section{Table 2 - 5: Non-CEO Compensation by Tenure Year in Fraud and Non-Fraud Firms}

This table reports results from OLS regression es timates of equation (1) comparing components of executive compensation across fraud and non-fraud firms during each year of tenure for non-CEOs. Total Comp is the total value of all forms of compensation for the current year; Bonus is the value of cash bonuses received during the year; Salary is the value of base salary received during the year; Rstock is the value of restricted stock awarded during the year; Option is the value of stock options awarded during the year. Fraud is an indicator variable set to 1 if the firm is a fraud firm, and 0 otherwise. Control variables are are defined in the Appendix. T-statistics are clustered at the firm level. $* * * * *$, and $*$ represent statistical significance at the $0.01,0.05$, and 0.10 levels respectively.

\begin{tabular}{|c|c|c|c|c|c|c|}
\hline \multirow[t]{2}{*}{ Tenure Year } & Total Comp & Bonus & Salary & Rstock & Option & Observations \\
\hline & \multicolumn{5}{|c|}{$\begin{array}{l}\text { Coefficient on dichotomous variable Fraud } \\
\text { (T-Statistic) }\end{array}$} & \\
\hline 1 & $\begin{array}{c}630 * * * \\
(4.53)\end{array}$ & $\begin{array}{c}112^{* * *} \\
(4.31)\end{array}$ & $\begin{array}{l}10^{* *} \\
(2.34)\end{array}$ & $\begin{array}{c}136^{* * *} \\
(6.85)\end{array}$ & $\begin{array}{l}242 * * \\
(2.53)\end{array}$ & 21,565 \\
\hline 2 & $\begin{array}{c}662 * * * \\
(9.52)\end{array}$ & $\begin{array}{l}172 * * * \\
(12.30)\end{array}$ & $\begin{array}{l}14 * * * \\
(3.05)\end{array}$ & $\begin{array}{c}118 * * * \\
(9.54)\end{array}$ & $\begin{array}{c}441 * * * \\
(8.53)\end{array}$ & 23,593 \\
\hline 3 & $\begin{array}{c}611 * * * \\
(8.58)\end{array}$ & $\begin{array}{c}166^{* * *} \\
(9.14)\end{array}$ & $\begin{array}{l}11^{* *} \\
(2.08)\end{array}$ & $\begin{array}{l}69 * * * \\
(3.75)\end{array}$ & $\begin{array}{c}363 * * * \\
(7.15)\end{array}$ & 25,346 \\
\hline 4 & $\begin{array}{c}702 * * * \\
(7.70)\end{array}$ & $\begin{array}{l}171 * * * \\
(10.00)\end{array}$ & $\begin{array}{c}9 \\
(1.31)\end{array}$ & $\begin{array}{l}76 * * * \\
(3.57)\end{array}$ & $\begin{array}{c}464 * * * \\
(6.44)\end{array}$ & 17,942 \\
\hline 5 & $\begin{array}{c}1,236 * * * \\
(8.79)\end{array}$ & $\begin{array}{l}329 * * * \\
(12.64)\end{array}$ & $\begin{array}{l}23 * * * \\
(2.58)\end{array}$ & $\begin{array}{c}224 * * * \\
(7.40)\end{array}$ & $\begin{array}{c}587 * * * \\
(5.19)\end{array}$ & 12,637 \\
\hline 6 & $\begin{array}{l}1,609 * * * \\
(8.06)\end{array}$ & $\begin{array}{c}206 * * * \\
(6.61)\end{array}$ & $\begin{array}{l}21^{*} \\
(1.86)\end{array}$ & $\begin{array}{c}-1 \\
(-0.04)\end{array}$ & $\begin{array}{c}1,237 * * * \\
(7.54)\end{array}$ & 9,059 \\
\hline 7 & $\begin{array}{c}1,281 * * * \\
(3.09)\end{array}$ & $\begin{array}{c}22 \\
(0.61)\end{array}$ & $\begin{array}{c}1 \\
(0.05)\end{array}$ & $\begin{array}{c}-202 \\
(-0.50)\end{array}$ & $\begin{array}{c}1,419 * * * \\
(6.94)\end{array}$ & 6,957 \\
\hline 8 & $\begin{array}{c}1,269 * * * \\
(4.99)\end{array}$ & $\begin{array}{c}91 \\
(1.62)\end{array}$ & $\begin{array}{c}0 \\
(0.01)\end{array}$ & $\begin{array}{c}299 * * * \\
(3.36)\end{array}$ & $\begin{array}{c}940 * * * \\
(5.53)\end{array}$ & 5,242 \\
\hline 9 & $\begin{array}{c}1,343 * * * \\
(3.61)\end{array}$ & $\begin{array}{c}74 \\
(0.86)\end{array}$ & $\begin{array}{c}-16 \\
(-0.70)\end{array}$ & $\begin{array}{c}139 \\
(1.15)\end{array}$ & $\begin{array}{l}643 * * \\
(2.29)\end{array}$ & 3,766 \\
\hline 10 & $\begin{array}{c}345 \\
(0.66)\end{array}$ & $\begin{array}{c}-33 \\
(-0.37)\end{array}$ & $\begin{array}{c}-13 \\
(-0.41)\end{array}$ & $\begin{array}{c}-229 \\
(-1.55)\end{array}$ & $\begin{array}{l}754 * * \\
(2.36)\end{array}$ & 2,709 \\
\hline $\begin{array}{l}\text { Controls } \\
\text { Industry Fixed Effects } \\
\text { Year Fixed Effects }\end{array}$ & $\begin{array}{l}\text { Yes } \\
\text { Yes } \\
\text { Yes }\end{array}$ & $\begin{array}{l}\text { Yes } \\
\text { Yes } \\
\text { Yes }\end{array}$ & $\begin{array}{l}\text { Yes } \\
\text { Yes } \\
\text { Yes } \\
\end{array}$ & $\begin{array}{l}\text { Yes } \\
\text { Yes } \\
\text { Yes } \\
\end{array}$ & $\begin{array}{l}\text { Yes } \\
\text { Yes } \\
\text { Yes } \\
\end{array}$ & \\
\hline
\end{tabular}




\section{Table 2 - 6: Executive Compensation Within Fraud Firms}

This table reports results from OLS regression estimates of equation (2) comparing components of executive compensation within fraud firms across named and non-named executives. Total Comp is the total value of all forms of compensation for the current year; Bonus is the value of cash bonuses received during the year; Salary is the value of base salary received during the year; Rstock is the value of restricted stock awarded during the year; Option is the value of stock options awarded during the year. Fraud is an indicator variable set to 1 if the firm is a fraud firm, and 0 otherwise. T-statistics are clustered at the firm level. ***,**, and * represent statistical significance at the 0.01 , 0.05 , and 0.10 levels respectively.

\begin{tabular}{|c|c|c|c|c|c|}
\hline & Total Comp & Bonus & Salary & Rstock & Option \\
\hline \multirow[t]{2}{*}{ Named } & $933 * *$ & -19 & $35 * * *$ & -62 & $918 * *$ \\
\hline & $(2.17)$ & $(-0.20)$ & $(3.50)$ & $(-0.79)$ & $(2.46)$ \\
\hline \multirow[t]{2}{*}{ Tenure } & $124 * * *$ & $52 * * *$ & $17 * * *$ & 8 & 35 \\
\hline & $(4.61)$ & $(9.36)$ & $(28.22)$ & $(1.59)$ & $(1.52)$ \\
\hline Firm Fixed Effects & Yes & Yes & Yes & Yes & Yes \\
\hline Year Fixed Effects & Yes & Yes & Yes & Yes & Yes \\
\hline Observations & 5,061 & 6,155 & 6,155 & 5,861 & 5,061 \\
\hline Adjusted R-Squared & 0.28 & 0.25 & 0.54 & 0.17 & 0.21 \\
\hline
\end{tabular}




\section{Table 2 - 7: Executive Compensation by Tenure Year Within Fraud Firms}

This table reports results from OLS regression estimates of equation (2) comparing components of executive compensation within fraud firms across named and non-named executives during each year of tenure. Total Comp is the total value of all forms of compensation for the current year; Bonus is the value of cash bonuses received during the year; Salary is the value of base salary received during the year; Rstock is the value of restricted stock awarded during the year; Option is the value of stock options awarded during the year. Fraud is an indicator variable set to 1 if the firm is a fraud firm, and 0 otherwise. T-statistics are clustered at the firm level. ***,**, and * represent statistical significance at the $0.01,0.05$, and 0.10 levels respectively.

\begin{tabular}{|c|c|c|c|c|c|c|}
\hline Tenure Year & Total Comp & Bonus & Salary & Rstock & Option & Observations \\
\hline & \multicolumn{5}{|c|}{$\begin{array}{l}\text { Coefficient on dichotomous variable Named } \\
\text { (T-Statistic) }\end{array}$} & \\
\hline 1 & $\begin{array}{l}-1,031 \\
(-0.64)\end{array}$ & $\begin{array}{c}-38 \\
(-0.47)\end{array}$ & $\begin{array}{c}26 \\
(1.47)\end{array}$ & $\begin{array}{c}-103 \\
(-0.65)\end{array}$ & $\begin{array}{c}-968 \\
(-0.65)\end{array}$ & 773 \\
\hline 2 & $\begin{array}{c}1,825^{* *} \\
(2.38)\end{array}$ & $\begin{array}{c}-18 \\
(-0.19)\end{array}$ & $\begin{array}{c}31 \\
(1.57)\end{array}$ & $\begin{array}{c}-26 \\
(-0.25)\end{array}$ & $\begin{array}{c}1,659 * * \\
(2.48)\end{array}$ & 903 \\
\hline 3 & $\begin{array}{c}-167 \\
(-0.16)\end{array}$ & $\begin{array}{c}-44 \\
(-0.31)\end{array}$ & $\begin{array}{c}24 \\
(1.13)\end{array}$ & $\begin{array}{c}-71 \\
(-0.59)\end{array}$ & $\begin{array}{c}-96 \\
(-0.10)\end{array}$ & 967 \\
\hline 4 & $\begin{array}{c}-36 \\
(-0.03)\end{array}$ & $\begin{array}{c}-8 \\
(-0.05)\end{array}$ & $\begin{array}{c}28 \\
(0.96)\end{array}$ & $\begin{array}{c}-6 \\
(-0.04)\end{array}$ & $\begin{array}{c}-39 \\
(-0.04)\end{array}$ & 637 \\
\hline 5 & $\begin{array}{l}1,083^{*} \\
(1.81)\end{array}$ & $\begin{array}{c}-9 \\
(-0.04)\end{array}$ & $\begin{array}{c}38 \\
(0.93)\end{array}$ & $\begin{array}{c}-43 \\
(-0.12)\end{array}$ & $\begin{array}{c}1,221 * * \\
(2.05)\end{array}$ & 439 \\
\hline 6 & $\begin{array}{l}4,695^{*} \\
(1.93)\end{array}$ & $\begin{array}{c}384 \\
(1.51)\end{array}$ & $\begin{array}{c}22 \\
(0.39)\end{array}$ & $\begin{array}{c}200 \\
(1.15)\end{array}$ & $\begin{array}{c}4,248 * * \\
(2.03)\end{array}$ & 302 \\
\hline 7 & $\begin{array}{c}9,947 * * \\
(2.23)\end{array}$ & $\begin{array}{c}181 \\
(0.75)\end{array}$ & $\begin{array}{c}2 \\
(0.02)\end{array}$ & $\begin{array}{c}-345 \\
(-0.90)\end{array}$ & $\begin{array}{c}9,934 * * \\
(2.29)\end{array}$ & 196 \\
\hline 8 & $\begin{array}{l}3,116 \\
(1.31)\end{array}$ & $\begin{array}{c}-39 \\
(-0.06)\end{array}$ & $\begin{array}{c}120 \\
(1.18)\end{array}$ & $\begin{array}{c}338 \\
(0.32) \\
\end{array}$ & $\begin{array}{l}2,183 \\
(1.42)\end{array}$ & 128 \\
\hline $\begin{array}{l}\text { Firm Fixed Effects } \\
\text { Year Fixed Effects }\end{array}$ & $\begin{array}{l}\text { Yes } \\
\text { Yes }\end{array}$ & $\begin{array}{l}\text { Yes } \\
\text { Yes }\end{array}$ & $\begin{array}{l}\text { Yes } \\
\text { Yes }\end{array}$ & $\begin{array}{l}\text { Yes } \\
\text { Yes }\end{array}$ & $\begin{array}{l}\text { Yes } \\
\text { Yes }\end{array}$ & \\
\hline
\end{tabular}




\section{Table 2 - 8: Portfolio Management Within Fraud Firms}

This table reports results from OLS regression estimates of equation (3) comparing portfolio management differences within fraud firm across named and non-named executives after the fifth year of their tenure. Shares Sold is the number of shares the executive sold during the year; Pct Shares Sold is the percentage of total shares held by the executive sold during the year; Pct Option is the percentage of executives total equity held in stock options; Firm Wealth is the percentage of the executive's total wealth held in firm equity; total wealth is the sum of firm bas ed wealth following Coles et al. (2013) and non-firm based wealth following Dittman and Maug (2007); Ch FimrWealth is the change in Firm Wealth. Named is an indicator variable set to 1 if the SEC named the executive as a perpetrator of fraud, and 0 otherwise. Control variables are are defined in the Appendix. T-statistics are clustered at the firm level. $* * *, * *$, and $*$ represent statistical significance at the $0.01,0.05$, and 0.10 levels respectively.

\begin{tabular}{l|ccccc}
\hline & Sh Sold & Sh Sold Pct & Option Pct & FBW & Ch FBW \\
\hline Named & $-338.086^{* *}$ & $-0.103^{* *}$ & $0.111^{* * *}$ & $0.091^{* * *}$ & $0.125^{* *}$ \\
Size & $(-2.35)$ & $(-2.11)$ & $(3.30)$ & $(3.39)$ & $(2.41)$ \\
& -48.704 & 0.023 & 0.012 & $0.039^{* * *}$ & $0.076^{* * *}$ \\
MTB & $(-0.77)$ & $(1.14)$ & $(1.01)$ & $(3.40)$ & $(3.90)$ \\
& $-17.203 * *$ & -0.000 & -0.000 & 0.001 & $0.004 *$ \\
Debt & $(-2.35)$ & $(-0.14)$ & $(-0.15)$ & $(0.63)$ & $(1.76)$ \\
& -518.310 & -0.197 & -0.046 & 0.091 & 0.224 \\
Return & $(-1.27)$ & $(-1.59)$ & $(-0.55)$ & $(1.19)$ & $(1.61)$ \\
Volatility & $-207.503 * * *$ & $-0.032 * *$ & -0.006 & -0.006 & $-0.071 * * *$ \\
& $(-4.07)$ & $(-2.15)$ & $(-0.58)$ & $(-0.66)$ & $(-4.65)$ \\
Geographic & 819.054 & $0.400 *$ & $0.259 * *$ & $-0.205 *$ & $0.669 * * *$ \\
& $(1.32)$ & $(1.92)$ & $(1.97)$ & $(-1.76)$ & $(3.48)$ \\
Segment & $-50.222 *$ & -0.010 & 0.001 & $0.020 * * *$ & $0.019 *$ \\
& $(-1.84)$ & $(-1.15)$ & $(0.16)$ & $(3.62)$ & $(1.90)$ \\
Firm Fixed Effects & -0.541 & -0.010 & -0.005 & $-0.009 * *$ & -0.005 \\
Year Fixed Effects & $(-0.02)$ & $(-1.28)$ & $(-1.13)$ & $(-2.04)$ & $(-0.55)$ \\
Observations & Yes & Yes & Yes & Yes & Yes \\
Adjusted R-Squared & Yes & Yes & Yes & & Yes
\end{tabular}




\title{
CHAPTER THREE: FRAUD CHARACTERISTICS AND SEC ENFORCEMENTS AGAINST INDEPENDENT AUDITORS
}

\author{
Erlina Papakroni \\ John Chambers College of Business and Economics, West Virginia University \\ epapakro@mix.wvu.edu
}




\subsection{INTRODUCTION}

Financial statements, filed with the SEC, are a joint collaboration of firm's management and independent auditor ${ }^{12}$ (Carcello, Hollingsworth, and Mastrolia 2011). Management prepares the financial statements, whereas the auditor attests to the reliability of the reported financial information (DeFond, Francis and Hallman 2016). When financial reporting fraud (FRF) is detected, the alleged fraudulent firm and/or managers face private civil class-action from shareholders and federal sanctions from regulatory agencies (Karpoff et al. 2008a). In addition to the fraudulent firms and managers, shareholders and regulatory agencies, i.e. the SEC and the Public Company Oversight Board (PCAOB), may pursue charges against the auditor. For instance, PCAOB oversees auditors' violations of Generally Accepted Auditing Standards (GAAS), PCAOB auditing standards and rules, and SEC Rules (Carcello et al. 2011). Thus, enforcements are not only issued against the fraudulent firms and/or managers, but also against auditors.

Prior literature has examined extensively the auditor's litigation risk (Kaplan and Williams 2013; Reffett 2010; Cornell et al. 2009; Kadous and Mercer 2012; Bonner et al. 1998b), however, little is known about the SEC enforcements against the auditor (DeFond et al. 2016). Primarily, SEC investigates federal securities laws violations and issues accounting and auditing enforcements releases (AAERs) (25 SEC Docket 2 1982) or litigation releases (LRs), against firms with materially misstated financial statements. The SEC has also found various violations by the auditors, such as violating the auditor independence rule (U.S. Securities and Exchange Commission 2015), or deficient audits, which is failure to gather sufficient competent audit evidence and to exercise due professional care (Beasley, Carcello, Hermanson and Neal 2013).

\footnotetext{
${ }^{12}$ In the rest of this study, "auditor" refers to independent/external auditors as distinguished from internal auditors. Also, this study does not distinguish between independent audit firms and auditors/partners working for them.
} 
The SEC finds auditing related violations in 17 percent (Eutsler, Nickell and Robb 2016) to 39 percent (Bonner, Palmrose and Young 1998) of the total investigated fraud cases. In these cases, the SEC finds the auditor responsible for failing to identify the FRF in due time and charges the auditor with auditing violations. Examining the AAERs/LRs, the evidence shows that in the remaining $61-83$ percent of the fraud cases, the SEC discloses two different findings regarding the auditor. In some cases, the SEC finds that the fraud scheme was concealed from the auditor or that the auditor was misled during the audit, and when there is no such finding in the remaining cases, the SEC is silent on the role of the auditor in auditing the fraudulent financial statements. In sum, the SEC has three different auditor related findings: the auditor is charged, the fraud scheme is concealed from the auditor, and there is no particular finding regarding the auditor, i.e. the SEC is silent.

Peecher et al. (2013) argue, theoretically, that the auditors' accountability framework depends on audit outcomes rather than the attributes of auditors' judgment process. According to this framework, the three SEC findings, charged, silent or concealed, are determined based on auditor's opinion on the audited financial statements and subsequent detection of the FRF. The overall auditing procedures followed during the auditing process are not taken into consideration. Thus, charged, silent and concealed findings are affected by the type and the extent of the misreporting in the financial statements. Further, the authors argue that the auditors' accountability framework should be a process-reward framework, where the auditors are rewarded for the auditing process regardless of subsequent FRF detection.

The purpose of this study is to examine the association of the three SEC's auditor related findings and the fraud characteristics, i.e. fraud duration, fraud amount, collusion, type of fraud and perpetrator's position in the fraudulent firm. The sample of fraudulent firms is identified 
through the AAERs/LRs issued by the SEC, where the company and/or manager was charged with Rule 10(b)-5 violation. In other words, Rule 10(b) charges companies and/or managers with the intent to misreport, thus the intent to commit fraud.

The results indicate a weak association between the fraud characteristics and the SEC's findings against the auditors. Collusion among perpetrators and asset misreporting fraud schemes increase the probability of the SEC charging the auditor as compared to the probability of being silent. Whereas the perpetrator's executive position decreases the probability of the SEC charging the auditor as compared to the probability of being silent. Also, in asset misreporting fraud cases, the SEC is more likely to charge the auditor as compared to finding that the fraud scheme is concealed from the auditor. Overall, only a few fraud characteristics are associated with the SEC's auditor related findings, which is not consistent with an outcome-penalty accountability framework. In contrast, the results indicate that the auditor type, whether the auditor is a Big N auditor or not, is significantly associated with the SEC's findings. More specifically, when the fraudulent financial statements are audited by a Big N auditor, the SEC is more likely to remain silent or to find that the fraud scheme is concealed from the auditor as compared to charging the auditor. Prior literature argues that Big N auditors provide better quality audits (DeAngelo 1981, Francis 2004). This evidence is more consistent with a process-reward accountability framework than an outcome-penalty accountability framework.

This study makes two important contributions. First, the findings of this study provide empirical insight into the discussion of whether the current regulatory system relies on audit outcomes or on attributes of auditors' judgment processes. The SEC's purpose in issuing enforcements against the auditor is to improve audit quality by holding auditors accountable. DeFond et al. (2011) find that the presence of the SEC regional offices or recent enforcements 
issued by the SEC significantly influence the audit quality of the independent auditor. Further, Carcello et al. (2011) find that the PCAOB inspection process has led to improved audit quality. The accountability framework, employed by the regulatory bodies in disciplining auditors, impacts audit quality. Thus, examining auditor accountability framework contributes to the current discussion on audit quality provided by the independent auditors.

Second, the findings provide insights to auditors in managing risks in subsequently detected FRF. When auditors fail to supply high audit quality, they face serious consequences, such as sanctions from the SEC (Beasley et al. 2013), litigation risk (Bonner et al. 1998b), reputation risk (Weber, Willennborg and Zhang 2008) and enhanced inspection from the PCAOB. Therefore, auditors are constantly trying to manage engagement risks (Johnstone and Bedard 2003, 2004) and to maximize audit quality in order to avoid facing any of the above consequences. One approach to manage perceived risk is resignation from high-risk clients (Bockus and Gigler 1998; Shu 2000). However, auditors are not always successful in avoiding risky clients. Issuance of an AAER/LR suggests that the auditor failed to identify a risky client in due time. Consequently, it is important that auditors take additional steps, during audit procedures, to reduce the risks associated with high-risk clients that were not identified during the client acceptance process. Thus, in an attempt to minimize engagement risk, it is essential for auditors to understand what aspects of audit process would decrease their likelihood to be named as a defendant by the SEC.

The rest of the paper is organized as follows: Section 2 provides a review of the accountability framework and develops the hypothesis. Section 3 describes the sample and the empirical model used in this study. Section 4 presents the results and section 5 concludes this study. 


\subsection{THEORETICAL BACKGROUND AND HYPOTHESIS DEVELOPMENT}

\subsection{SEC Enforcements and Findings}

Publicly held companies are required, under Federal securities laws, to have their financial statements audited by an independent auditor prior to their filing with the SEC. The financial statements remain the responsibility of the company's management, however, the auditor provides reasonable assurance that they are free of material misstatement, and fairly represent the financial position of the company (AU Section 508: Reports on Audited Financial Statements). Auditors are the gatekeepers, who verify or assess corporate disclosures, to protect investors (Coffee 2004).

The SEC has continuously emphasized the fundamental role that the gatekeepers, i.e. auditors, play in achieving its mission to protect investors and the capital market. Former Chair of the SEC, Mary Jo White, considered auditors the key gatekeepers who ensure shareholders of highquality financial reports (White 2015). On a similar note, Andrew Ceresney, former Director of Division of Enforcement of the SEC, considered independent auditors to be critical gatekeepers who attest that issuers are making timely, comprehensive, and accurate disclosure (Ceresney 2016a). Given the SEC's focus on financial reporting (White 2013), auditors' work warranted tighter supervisor. Therefore, 'Operation Broken Gate' and Financial Reporting and Audit Task Force (referred to as FRAud ${ }^{13}$ Task Force) were introduced in 2013 as part of the Division of Enforcement. 'Operation broken gate' seeks 'to identify auditors who fail to carry out their duties and responsibilities consistent with professional standards' (SEC 2013-207). FRAud Task Force's mission is to detect and prevent financial reporting and accounting fraud (Ceresney 2013).

The SEC's tighter supervision resulted in a substantial increase, as compared to prior years, in enforcements issued for undetected FRF. In 2016, the SEC filed 868 enforcement actions, the

\footnotetext{
13 "FRAud" is the acronym of Financial Reporting and Audit.
} 
most in the SEC's history (Agency Financial Report 2016), and a substantial increase from 807 and 755 enforcements in 2015 and 2014, respectively (Agency Financial Report 2015, 2014). These initiatives also resulted in a substantial increase in the number of auditor proceedings under Rule 102(e), which regulates auditor accountability and independence, from 37 respondents in 2013 to 76 in 2015 (Ceresney 2016b). Also in 2015, the SEC charged two national audit firms, BDO and Grant Thornton, which were the first audit failure enforcements against a national audit firm since 2009 (Ceresney 2016b). The following example illustrate a case when the SEC charges the auditor for missing the FRF.

"The complaint alleges that KPMG and its partners permitted Xerox to manipulate its accounting practices to close a $\$ 3$ billion "gap" between actual operating results and results reported to the investing public."14

Yet evidence shows that the SEC charges the auditor, in total, in as low as 17 percent of undetected fraud cases (Eutsler et al. 2016; Kedia et al. 2017). This finding is, also, in contrast with the Coffee (2004)'s argument that failure in independent auditing was the key factor of 20012002 fraud cases. In cases when the auditor is not charged, the SEC either finds that the FRF was concealed from the auditor or is silent on the auditor's role when there is no such finding. Thus, in certain cases, the SEC finds that the fraud scheme is concealed from auditor or that the auditor is misled during the audit. In other cases, the SEC does not have such particular finding regarding the role of the auditor in the detected FRF and remains silent. The following examples illustrate the finding when the SEC finds that the FRF is concealed from the auditor or the auditor is misled.

“...Olesnyckyj misled Monster's outside auditors in an attempt to hide the backdating scheme by providing documentation to them that misrepresented the grant date of the stock option awards.” LR 20004; AAER 2558 - February 15, 2007.

${ }^{14}$ LR 17954; AAER 1709 - January 29, 2003 
"The complaint also alleges that Smith, Laskey, and Brooks took steps to prevent Quest's independent auditors from discovering the backdating, including the use of false written consents by Quest's board of directors." LR 20950; AAER 2949-March 12, 2009.

A priori all material misstatements, subsequently detected, are concealed from the auditors. In other words, the FRFs investigated by the SEC indicate that the auditor failed to detect them during the auditing procedures. If issuance of an AAER/LR is a measure of low audit quality (DeFond and Zhang 2014) because the auditor failed to detect a material misstatement, it is important to examine those cases when the SEC did not find the audit deficient.

\subsection{SEC Enforcements and Accountability Framework}

There is a relatively sparse academic literature that examines the SEC's enforcements against the auditors (Kedia et al. 2017). Three studies, Kedia, Khan and Rajgopal (2017), Eutsler, Nickell and Robb (2016), and Rollings and Bremser (1997) examine the SEC's decision to charge the auditor as a defendant when FRF is subsequently detected. Table 3 - 1 provides a summary of these three studies. There are two literature gaps that these three studies have yet to address. The first gap relates to the SEC's auditor related findings. All three studies examined a binary finding of the SEC, whether to charge the auditor as the defendant or not to charge the auditor. Analysis of the AAERs/LRs indicates that there are three, not to two, possible auditor related findings following the investigation of an alleged fraud by the SEC. Distinguishing among the three SEC's findings, described in detail in section 2.1 (i.e. charged, silent and concealed), is important to auditors. Auditors are constantly trying to minimize litigation risks, and a concealment finding from the SEC, may lower their litigation risks.

Given the variability of findings that the auditors face from the SEC, it is important to examine the accountability framework that the SEC employs. In a theoretical study, Peecher et al. (2013) observed that auditors' accountability framework is predominantly based on outcome 
judgment and penalties. The auditors' performance is judged based on their conclusion together with subsequent adverse financial statement outcomes, and it is often manifested in the form of penalties. This type of framework motivates auditors to have a short-term compliance-based behavior slightly above the noncompliance threshold in order to avoid penalties. The authors further argue that an accountability system, based on the audit process judgment and reward, motivates auditors and increases audit quality by rewarding auditors for well-justified judgment processes, performance exceeding minimum compliance threshold, and improvement in fraud detection procedures.

This study examines whether the current enforcement system employed by the SEC, in overseeing auditors, is an outcome-penalty based framework or process-reward based framework. In an outcome-penalty based framework, the SEC's findings, charged, silent or concealed, are determined based on the auditing outcome. The penalties that SEC enforces against the auditor are affected by the FRF that the auditor failed to detect. In a process-reward system, the penalties, or the lack of, that the SEC enforces against the auditor are not affected by the FRF that was not detected. Under such accountability framework, the SEC's findings, charged, silent and concealed, are determined by examining the auditing process carried out by the auditor, and disregarding the auditing outcome, i.e. missed FRF.

\section{[Insert Table 3-1 here}

The second gap relates to examining the fraud characteristics and their impact in the three SEC's findings on the auditor. Prior literature has examined various key factors that increases or decreases the probability that the auditor is charged or not charged by the SEC. However, variables that relates to fraud characteristics are rarely examined in the literature. Kedia et al. (2017) and Eutsler et al. (2016) control only for the violation tenure and the type of the violation. Whereas 
Rollins and Bremser (1997) consider only the type of violation. Also, prior studies on auditors' overall litigation risks have examined only a few variables that capture characteristics of the FRF act. For instance, Bonner et al. (1998a) examined whether certain fraud types result in a higher likelihood of litigation against independent auditors, while controlling for fraud tenure. In a footnote, the authors state that they attempted to measure several other control variables, such as whether management lied to the auditor, whether collusion was involved, the specific office of the auditing firm primarily responsible for the client, and the importance of the client to the auditor, however, sufficient information was not disclosed. Since 1998, over 20 years of additional data are available to supplement the design used by Bonner et al. (1998b). This study addresses these two literature gaps by examining the association of the SEC's findings (i.e. charged, silent and concealed) with the fraud scheme characteristics. Further, given prior literature findings that auditor accountability framework relies on audit outcome rather than on audit process (Peecher et al. (2013); Eutsler et al. (2016); Reffett (2010)), this study examines empirically, the auditor's accountability framework. More specifically, this study examines whether auditing outcomes, operationalized as undetected fraud characteristics, significantly impact the SEC's decision to charge the auditor, to find that the fraud was concealed from the auditor, or to be silent. Hypothesis one follows:

H$_{1}$ : The SEC's auditor related findings are associated with fraud scheme characteristics. 


\subsection{METHODOLOGY}

\subsection{Sample}

The SEC's enforcement activities are carried out by the Division of Enforcement, founded in 1972, and are reported in the issuance of an AAER or a LR (25 SEC Docket 2 1982) ${ }^{15}$. Given the limited amount of resources, the SEC investigates only misreporting cases which are expected to have an significant economic impact (Dechow, Ge, Larson, and Sloan 2011). The SEC receives the indications of violating firms from various sources (Dechow, Sloan and Sweeney 1996), such as (i) reviews of Securities Act filings (1933, 1934), (ii) market surveillance of programs of the New York Stock Exchange (NYSE) and National Association of Securities Dealers and (iii) public complaints, tips, referrals from other law enforcement agencies, and the financial press. As of April 2019, the SEC has issued 4031 AAERs. An AAER does not have a standardized format and the information disclosed in each AAER vary by case. However, most AAERs follow similar structure as presented in Figure 3 - 1. The head of an AAER includes the date it was issued, the title and the identification number of the document. The first paragraph, after the title, provides information about the judicial district in which the case was prosecuted, the defendant and the final decision issued. The second paragraph describes the alleged misreporting scheme by naming the organization involved, the type of misreporting committed, duration of the misreporting, estimation of the misreported amount, the individuals, organizations

\footnotetext{
${ }^{15}$ From its beginning in 1937, the SEC had been issuing Accounting Series Releases (ASRs), primarily issued to inform interested parties on accounting and auditing matters. On April 15, 1982, SEC announced that the previously issued ASRs would be substituted with two types of releases, namely Financial Reporting Releases (FRRs) and Accounting and Auditing Enforcement Releases (AAERs). FRRs are used to disclose updates of the codifications of financial reporting policies, whereas AAERs are used to announce accounting and auditing matters related to the SEC's enforcement activities (25 SEC Docket 2 1982).
} 
or independent auditor involved in the misreporting scheme and other information deemed relevant by the SEC.

\section{[Insert Figure 3-1 and Figure 3-2 here]}

The amount of details disclosed about the misreporting scheme varies substantially in each AAER, and there is no official explanation provided on how the information disclosure is determined. The last paragraph enumerates the rules that the defendants violated and the penalties that are enforced against them. The final sentence in an AAER lists other AAERS or enforcement documents that have been prior issued on the same investigated case. A LR follows a very similar structure as an AAER. An illustration of a LR is presented in Figure 3 - 2.

This study uses two independent datasets to identify the fraud firms named in the AAERs and/or LRs, and the characteristics of the respective misreporting schemes. The first database is developed by Dechow, Ge, Larson and Sloan (2011) (herein after Dechow dataset) and is available for purchase through Haas School of Business at University of California Berkeley ${ }^{16}$. The second dataset, named AAER/LR database, is developed by The Institute for Fraud Prevention's (IFP) ${ }^{17}$ (here in after IFP dataset) and is available through a data grant process.

To develop the Dechow dataset, Dechow et al. (2011) examined the AAERs issued by the SEC since 1987 and identified 2,190 AAERs with $676^{18}$ unique firms. The initial database has been continuously updated. The latest version of database was purchased on April 19, 2017. The document that accompanies the purchase of the database states that it consists of 3,813 AAERs (1,540 firm misstatement events) issued between May $17^{\text {th }}, 1982$ and September $30^{\text {th }}, 2016$. The

\footnotetext{
${ }^{16} \mathrm{http}: / /$ accounting.haas.berkeley.edu/cfrm/aaer-dataset.html

${ }^{17} \mathrm{http}: / /$ www.theifp.org/about.html

18 Typically, the SEC issues multiple AAERs/LRs while each fraud case is being investigated.
} 
initial number of 3,813 AAERs is reduced to 3,556 after leaving out missing AAERs and AAERs that do not mention a specific company name. Also, the database contains 1,019 firm misstatement events that affect at least one of the firms' quarterly or annual financial statements.

The IFP database includes 882 fraud cases identified through the AAERs and the LRs issued by the SEC as of 2015. Part of these fraud cases were identified by the first and the second COSO reports. The first COSO report identified 294 fraud cases for 1987-1997 period (Beasley, Carcello and Hermanson 1999) and the second COSO report identified 347 cases (Beasley et al. 2010). Out of the total 882 fraud cases, 177 cases were not coded either for missing AAERs/LRs or missing GVKEY for the firm involved in the misreporting.

The Dechow dataset identifies the misreporting firms through the AAERs, whereas the IFP datasets uses both AAERs and LRs to identify the misreporting firms. There is an 80 percent overlap of the identified misreporting cases between the two datasets. Both datasets include only the enforcements where the company and/or officers are charged with Rule 10(b)-5 violation. This rule constitutes the primary antifraud statute included in Section 10(b) of the 1934 Securities and Exchange Act (Carcello and Nagy 2004). In other words, Rule 10(b) charges companies and/or managers with the intent to misreport, thus the intent to commit fraud. The sample for this study consists of publicly traded firms that misstated their financial statements. These fraudulent firms are identified though the AAERs/LRs issued by the SEC, and where Rule 10(b)-5 is listed as a violation.

The final sample of misreporting firms in this study is obtained by merging Dechow dataset and the IFP dataset initially by the CIK number, then by firm name, and lastly by AAER number. In the following section and in Appendix A, each variable is defined, and the dataset sources is provided. 


\subsection{Empirical Model}

\subsubsection{Dependent variable: SEC's Findings}

The SEC makes three different auditor related findings in the AAERs/LRs issued. In some cases, the SEC charges the auditors for negligent audit or violation of anti-fraud statutes (Beasley et al. 2013). In other cases, the SEC finds that the fraud act was concealed from the auditor. In the rest of the cases, the SEC is silent, i.e. neither charges nor proclaims that the fraud scheme was concealed. The dependent variable in this study is the SEC's auditor related finding when the firm and/or executives are charged with Rule 10(b)-5 violation. The IFP dataset has an indicator variable 'Concealed from Auditor', which equals 1 if the SEC specifically stated that the fraud scheme was concealed from auditor and 0 otherwise. The fraud cases where 'concealed from auditor' equals 0 are filtered out, and then the AAERs, identified in Dechow dataset, are used to determine whether the SEC charges the auditors or whether the SEC is silent. Thus, the depend variable in this study takes three values: charged, silent or concealed.

\subsubsection{Independent Variable: Fraud Characteristics}

Prior studies examining the auditors' litigation risk have controlled for different fraud characteristics and found mixed results. Eutsler et al. (2016) found that including a going concern issue (GC) in the audit opinion letter increases the probability of an AAER being issued against the auditor. In their model, the authors controlled for fraud tenure, fraud type measured as revenue or disclosure fraud and number of misstated accounts. Only the number of misstated accounts statistically significantly increased the probability of an enforcement being issued by SEC against the auditor. Kaplan and Williams (2013) find the opposite results. The authors report a negative association between GC reporting and auditor litigation, arguing that auditors deter lawsuits by issuing a GC reports to financially stressed clients. Further, Bonner et al. (1998b) analyzed the 
AAERs issued by the SEC and found that auditors have a higher probability of being sued for commonly occurring fraud and frauds arisen from fictitious transactions. The authors included the number of years with misstated financial information to control for fraud duration. Lastly, Rollins and Bremser (1997) examined three type of fraud violation as a determinant of the probability of the SEC enforcement against the auditor. The three violations included falsification of accounting records by the management, asset and/or revenue overstatement and inadequate disclosure in the financial statement. The results found that only the inadequate disclosure increased the probability of an SEC enforcement action against the auditor.

In sum, prior studies have controlled for some aspects of fraud characteristics in auditor litigation risk, yet the key fraud characteristics, regarding fraud amount, fraud scheme and perpetrators, are excluded from their models. This study examines the impact of key fraud characteristics on the probability of the SEC's auditor related findings. The key fraud characteristics included in the model are: fraud duration, type of fraud, which include revenue fraud, asset misreporting fraud and disclosure fraud, fraud amount, number of perpetrator and perpetrator executive position within the fraud firm.

Fraud duration (FR_DURATION) is expected to positively increase the probability of the SEC enforcements against the auditor. Prior literature has found a positive but non-significant result when fraud duration is measured in years (Bonner et al. 1998b; Eutsler et al. 2016), however when fraud duration is measured in months, the results are positive and significant (Kedia et al. 2017). In several cases, fraud schemes last only a couple of months and affect only limited number of quarterly or annual financial statements. Therefore, FR_DURATION is measured in this study in the number of quarterly financial statements affected by the misstatement. This variable is available in Dechow dataset. 
Every fraud scheme investigated by the SEC is unique, however the following three fraud schemes are expected to have a significant impact. Revenue Fraud (REVFraud) is measured as a binary variable where 1 indicate whether fraudulent firm misreported its revenue account and 0 otherwise. Prior literature cites meeting and beating earnings prediction as one of the common pressures to commit fraud. Hence, the income statement accounts are the most commonly manipulated to achieve that goal. Fraudulent schemes often affect balance sheet accounts, as well. The next type of fraud examined in this study is asset misreporting fraud (AMFraud), which equals 1 if assets are misreported and 0 otherwise. Finally, failing to disclose material information (DISCFraud) is examined in prior literature as having a significant effect on litigation risk (Eutsler et al. 2016; Rollins and Bremser 1997). This variable is also measured as binary variable, where it equals 1 if the fraudulent firm failed to disclose information in the financial statements and 0 otherwise.

Prior literature (Bonner et al. 1998b; Dechow et al. 2011; Kaplan and Williams 2013) and current studies (Eutsler et al. 2016; DeFond et al. 2016; Kedia et al. 2017) have not controlled for or examined the effect of the misreported amount, number and position of the fraud perpetrator. The primary reason appears to be the lack available data. Bonner et al. (1998b) stated in a footnote that they attempted to collect additional information on whether management lied to the auditor or whether collusion was involved, however there was not sufficient information. Since 1998, there are about 20 years of additional data available and the IFP dataset possesses the information on the misreported amount (FR_AMOUNT), measured in in U.S. dollars. Auditors are found more responsible for missing high-profile fraud schemes that involve high-rank executives such as CEO, $\mathrm{CFO}$ or $\mathrm{COO}$, than low profile fraud schemes such as lower level employee. Therefore, the position of the perpetrator named in the AAERs/LRs (PERP_POSITION), available in the IFP dataset, is 
an indicator variable where it is equal to 1 if the perpetrator is the CEO, COO or the president of the fraudulent firm and 0 otherwise. Lastly, the IFP dataset has three indicator variables on the different position held by the fraud perpetrators. The sum of these three indicator variables (COLLUSION) indicate whether two or more perpetrators colluded to carry out the fraud scheme.

\subsubsection{Control Variables: Firm characteristics and auditor characteristics}

Prior literature controls for two primary groups of control variables, firm characteristics and auditor characteristics. Firm size (FIRM_SIZE) is argued in the literature to be a key determinant of the litigation against the auditor (Eutsler et al. 2016). Furthermore, firm size affects the auditor's choice, i.e. bigger firms tend to choose Big Four auditors (PWC, KPMG, EY and Deloitte). Prior literature argues that bigger auditors are less vulnerable to litigations due to increase availability of resources (Bonner et al. 1998b). Firm size is measured as the ratio of total revenues over the total assets on the year prior to the first misreported year or year prior to that in cases where data was missing. Financial distress is a common red flag for fraud, therefore bankruptcy filing from the firms increase the likelihood of litigation against the auditors (Kaplan and Williams 2013). Issuance of a going concern issue (GC) by the independent auditors increases the likelihood of litigation against the auditor, since a going concern is an indicator of distress (DeFond et al. 2016; Kaplan and Williams 2013), hence the auditors should have been aware of higher fraud risk. GC is measured as a binary variable and equals 1 if the auditor issued a going concern in their report.

Certain characteristics related to the auditor are found by prior literature to either increase or decrease as the likelihood of enforcement from the SEC. Kedia et al. (2017) found that the SEC is significantly less likely to name a Big $\mathrm{N}$ auditor as a defendant. In addition to that, being classified as a Big $\mathrm{N}$ auditor (being it Big 4 or Big 5 or Big 6) increases the auditors' prestige 
(Rollins and Bremser 1997) which is associated with higher audit quality and less enforcement risk. Therefore, a binary variable (BIG-N) is included to indicate whether the auditor is one of the five audit firms: PricewaterhouseCoopers LLP, Ernst \& Young LLP, KPMG LLP, Deloitte \& Touche LLP, and Arthur Andersen LLP, and 0 otherwise. Auditor's tenure (AUDIT_TENURE) with the client firms is found to be negatively associated with fraudulent reporting (Carcello and Nagy 2004). Therefore, a variable is included to measures the number of consecutive years an auditor audited the same client until the last year of the fraud duration.

In 2002 after the passing of Sarbanes-Oxley (SOX) Act, there was a change in the regulation of auditing profession. Prior to 2002, public auditors were supervised through a peer review system regulated by the American Institute of Certified Public Auditors (AICPA). Then, in the wake of large FRF scandals, SOX Act was passed, and the Public Company Auditing Oversight Board (PCAOB) was established to provide oversight of the auditing profession. Given the change in auditing oversight, a dummy year variable is included to control for before and after SOX fraud cases. Based on prior literature, the following empirical model is proposed.

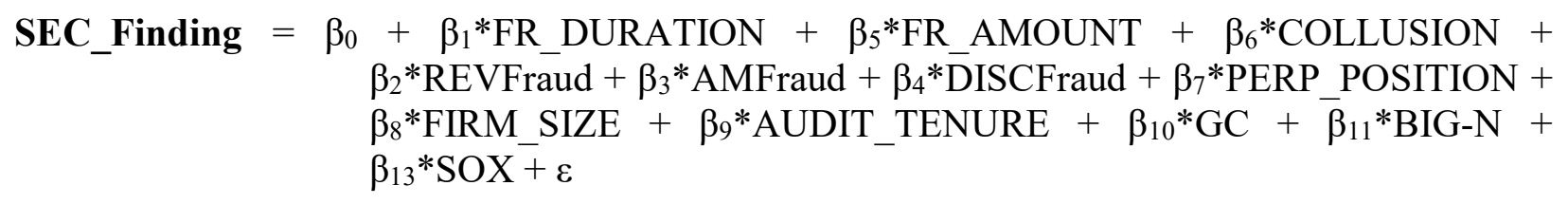
$\beta_{2} *$ REVFraud $+\beta_{3} *$ AMFraud $+\beta_{4} *$ DISCFraud $+\beta_{7} *$ PERP_POSITION + $\beta_{8} *$ FIRM_SIZE $+\beta_{9} *$ AUDIT_TENURE $+\beta_{10} *$ GC $+\bar{\beta}_{11} *$ BIG-N + $\beta_{13} * \mathrm{SOX}^{-} \varepsilon$

\subsection{DESCRIPTIVE STATISTICS AND RESULTS}

\subsection{Descriptive Statistics}

The final sample in this study consist of 196 fraudulent firms. Table 3 - 2 reports the descriptive statistics of the sample. The first column reports full sample descriptive statistics and the next three columns report the descriptive statics by the SEC's finding. On average, 11.7 quarterly financial statements are misreported, and the fraud scheme was perpetrated by 1.6 
individuals. Majority of the perpetrators, 64.8 percent (127 perpetrators) hold top executive positions, i.e. CEO, $\mathrm{COO}$ or president, and the rest, 35.2 percent (69 perpetrators) hold lower level positions. The three types of fraud examined in this study are not mutually exclusive as perpetrated fraud schemes are complex and affect more than one type of financial statements. Therefore, the total fraud cases involving revenue, asset misreporting and disclosure fraud exceeds $100 \%$. There are 122 (62.2 percent) fraud cases where the revenue is misreported, 49 ( 25 percent) where assets are misreported, and 74 (37.8 percent) where the fraud firm failed to disclose significant information in the financial statements. On average, the auditors have audited the financial statements for 3 years and issued a going concern in the audit report in 15.8 percent ( 31 cases) of the time. Most of the auditors, 78.6 percent (154 cases) are BIG-N auditors. Lastly, over half of the fraud cases, 54.1 percent (106 cases) terminated before the passage of the SOX act and 45.9 percent (90 cases) terminated after the passage of SOX act.

In most of the fraud cases in the sample, 122 cases (62.2 percent), the SEC finds that the fraud scheme was concealed from the auditor. In 45 cases ( 23 percent), the SEC remains silent and does not have any particular finding regarding the auditor, and in the remaining of the 29 cases (14.8 percent), the SEC charges the auditor for auditing related violations. Recent studies report similar charging rate of auditors in the AAERs/LRs. Eutsler et al. (2016) and Kedia et al. (2017) find that auditors are charged in $17 \%$ of the cases. Earlier studies report a higher percentage of auditors being charged in the AAERS. Rollins and Bremser (1997) found that in $1 / 3$ of the cases the SEC issued AAERs against the auditors, for the AAERs issued from 1982 through August 1991. Dechow et al. (1996) found 165 out of 436 AAERs (37\%), between April 1982 and December 1992, to be issued against auditors for violations of auditing standards. Bonner et al. 
(1998b) found that 39\% of the 261 firms subject to SEC Enforcement actions between 1982-1995, have enforcements issued against auditors as well.

In comparing the sample by the SEC's finding, fraud cases where the SEC is silent differs from the other two cases. On average, they last longer, 13.6 quarterly financial statements are misreported as compared to charged cases, where 11.7 and concealed cases, 11.1 quarterly financial statements are misreported. Silent cases also involve fewer perpetrators, 1.1, on average, than the other two cases, and they also have the lowest percentage, 53.3 percent of top executives who have a high ranked position, as compared to 72.4 percent in charged group and 76.2 percent in the concealed group. In comparing the auditor characteristics, the fraud cases where the auditor is charged have the shortest audit tenure (2.8 years), the lowest percentage of the Big-N auditors (55.2 percent) and the highest percentage of fraud schemes terminated before the passing of SOX act, as compared to the other two groups.

Table 3 - 3 reports the Pearson correlation coefficients among the independent variables. The results indicate a statistically significant and positive Pearson correlation among the fraud characteristic indicators. Fraud duration has a positive and significant correlation with fraud amount $(+0.38$, two tailed $p<0.01)$ and significant negative correlation with revenue fraud $(-0.24$, two tailed $\mathrm{p}<0.01)$. It is interesting to notice that collusion has a positive and significant correlation with perpetrator position $(+0.75$, two tailed $p<0.01)$. Fraud cases where top executives are involved in the fraud schemes have more perpetrators in total than fraud cases where top executives are not involved. ${ }^{19}$ Regarding auditor characteristics, audit tenure has positive and significant correlation with the fraud duration $(+0.40$, two tailed $\mathrm{p}<0.01)$ and fraud amount $(+$

\footnotetext{
19 This result needs to be interpreted with caution as the IFP dataset did not indicate the total number of perpetrators involved, rather it indicated whether the perpetrators are top executive, lower level executives or part of the board of directors. The total sum of these three indicator variables yielded the number of the perpetrators in this study.
} 
0.19 , two tailed $\mathrm{p}<0.01)$. Lastly, SOX has a positive and significant correlation with fraud duration $(+0.40$, two tailed $\mathrm{p}<0.01)$ and audit tenure $(+0.57$, two tailed $\mathrm{p}<0.01)$, but a negative and significant correlation with collusion $(-0.17$, two tailed $\mathrm{p}<0.05)$. Thus, fraud cases that terminated after the SOX act was passed last longer, involve less perpetrators, and the auditor has a shorter tenure with the fraudulent firm.

[Insert Table 3 - 2 and Table 3 - 3 here]

\subsection{Multivariate Tests}

This study uses Multinomial Logit Regression ${ }^{20}$, where the charged finding is used as reference category, to test hypothesis one $\left(\mathrm{H}_{1}\right)$. The Multinomial Logit Regression compares the odds of the SEC finding that the fraud scheme is concealed from the auditor or the odds of the SEC remaining silent to the odds of the SEC charging the auditor. The reference group is 'charged', and it is compared to 'concealed' and 'silent' cases. Prior literature compared charged to not charged ${ }^{21}$, whereas this study compares charged to concealed and charged to silent.

Hypotheses $\mathrm{H}_{1}$, which argues that the SEC's auditor related findings are associated with fraud characteristics, is tested using Model 1.

\section{Model 1:}

\footnotetext{
${ }^{20}$ Based on the auditor's desirability of the SEC finding, there is a logical order that would provide a ranking of the three findings. An auditor would prefer to receive a concealed finding from the SEC, rather than a silent statement, and the least desirable is to be charged. Thus, concealed, silent and charged is a logical order from the auditor's perspective. However, it is not possible to use Ordinal Logit Regression as the Proportional Odds assumption is not satisfied.

${ }^{21}$ Untabulated results of binary logistic regression, where charged equals 1 and not charged equals 0 , replicate the same findings as Kedia, Khan and Rajgopal (2017), using the final sample in this study. More specifically, the Big N auditors are less likely to be charged by the SEC $\left(\beta_{\mathrm{BigN}}=-1.99\right.$, two-tailed $\left.\mathrm{p}<0.01\right)$. However, the findings show that including a going concern issue (GC) in the audit report does not significantly affect the likelihood of the SEC charging or not charging the auditor. Hence, the findings in Eutsler, Nickell and Robb (2016) are not replicated in our sample.
} 


$$
\begin{aligned}
\text { SEC_Finding }=\beta_{0}+ & \beta_{1} * \text { FR_DURATION }+\beta_{2} * \text { FR_AMOUNT }+\beta_{3} * \text { COLLUSION }+ \\
& \beta_{4} * \text { REVFraud }+\beta_{5} * \text { AMFraud }+\beta_{6} * \text { DISCFraud }+\beta_{7} * \text { PERP_POSITION }+ \\
& \beta_{8} * \text { FIRM_SIZE }+\beta_{9} * \text { AUDIT_TENURE }+\beta_{10} * \mathrm{GC}+\beta_{11} * \mathrm{BIG}-\mathrm{N}+ \\
& \beta_{12} * \mathrm{SOX}+\varepsilon
\end{aligned}
$$

Table 3 - 4 reports the results from multinomial logistic regression, detailed in Model 1. The first part of the table reports multinomial regression results when comparing the probability of the SEC charging the auditor to the SEC remaining silent regarding the auditor. The results indicate partial support for the hypothesis $\mathrm{H}_{1}$. The results show that the coefficients of fraud severity indicators, collusion, asset misreporting fraud and perpetrator's position are significantly different from zero, when comparing the odds of the SEC charging the auditor to remaining silent. More specifically, the effects of COLLUSION $\left(\beta_{3}=-1.77\right.$, two-tailed $\left.p<0.01\right)$ and AMFraud $\left(\beta_{5}\right.$ $=-1.20$, two-tailed $\mathrm{p}<0.05)$ are negative and significant, whereas PERP_POSITION $\left(\beta_{7}=+2.42\right.$, two-tailed $\mathrm{p}<0.05)$ is positive and significant. Thus, these results indicate that as the number of perpetrators increases, the odds of the SEC remaining silent regarding the auditor decreases compared to the odds of the SEC charging the auditor. Also, in asset misreporting fraud type, the SEC is less likely to remain silent compared to charging the auditors. Therefore, as fraud characteristic changes, the severity of the SEC's findings increases as well. However, the opposite it true regarding the perpetrator's position. In fraud cases perpetrated by top executives, the SEC is more likely to remain silent than to charge the auditors. Perpetrators in higher positions receive less severe finding from the SEC. The remaining fraud severity indicators do not have a significant association with the SEC's findings.

The second part of Table 3 - 4 reports regression results when comparing the probability of the SEC charging the auditor to the SEC finding that the fraud scheme was concealed from the 
auditor. Among the fraud characteristic indicators, only the coefficient of the asset misreporting indicator is negative and significant $\left(\beta_{5}=-0.83\right.$, two-tailed $\left.\mathrm{p}<0.1\right)$. Thus, in asset misreporting fraud type, the SEC is less likely to find that the fraud scheme is concealed from the auditor compared to charging the auditors.

The results are not consistent with the outcome-penalty accountability framework employed by the SEC against the auditors and as argued by Peecher et al. (2013) because only some of the fraud characteristic indicators are significantly associated with higher probability of the SEC charging the auditor. Hence, the SEC's finding regarding the auditor is not affected by the fraud scheme characteristics. Indicating further that the auditors' accountability framework is more consistent with a process-reward framework, where the auditors are rewarded for the procedures followed during the auditing process despite the ultimate result of not detecting FRF during the auditing procedures. In support of this conclusion, the results indicate that the coefficient on auditor type is positive and significant when comparing the odds of the SEC charging the auditor, first, to the odds of the SEC remaining silent $\left(\beta_{9}=+2.96\right.$, two-tailed $\mathrm{p}<$ 0.01), and second, to the odds of the SEC finding that the fraud scheme was concealed from the auditor $\left(\beta_{9}=+1.86\right.$, two-tailed $\left.\mathrm{p}<0.01\right)$. Kedia et al. (2017) finds the same results regarding Big $\mathrm{N}$ auditors. The authors find that the SEC is less likely to charge Big-N auditors, and when Big-N auditors are charged, the SEC pursues less severe outcomes as compared to other auditors. Lastly, the relatively small percentage of the fraud cases where the auditor is charged, supports my conclusion that, more often than not, the auditor is not charged for subsequently detected fraud cases, but it is reworded instead.

[Insert Table 3 - 4 here] 


\subsection{CONCLUSIONS}

Publicly traded companies are required to have their financial statements audited by an independent auditor prior to filing them with the SEC. The SEC has continuously emphasized the fundamental role that the auditors play in achieving its mission to protect investors and the capital markets. In 2013, the SEC introduced Operation Broken Gate and Financial Reporting and Audit Task Force to oversee auditor's performance, which increased substantially the number of the enforcements issued against the auditors. Yet the SEC names the auditor, in as low as $17 \%$ of total enforcements issued against fraudulent firms (Eutsler et al. 2016; Kedia et al. 2017). As such, there exists a discrepancy between the SEC's emphasis on the auditors' role as a gatekeeper and the total enforcements issued against the auditors. In this study we examine the accountability framework used by the SEC in issuing enforcements against the auditor. In a theoretical study, Peecher et al. (2013) observes that the regulatory entities, such as the SEC use an outcome-penalty accountability framework to assess auditors' performance. The penalties that the auditors face from the regulatory entities, such as fines, punitive damages and license removal, are determined based on the audit outcome, such as adverse financial statement outcome, which include bankruptcy, fraud or decrease in market capitalization. Further the authors suggest that the regulatory entities should employ a process-reward accountability framework, where the auditors are rewarded based on the attributes of auditors' judgement processes, such as use of innovative audit procedures.

The results indicate a weak association between the fraud characteristics and the SEC's findings. Collusion among perpetrators and asset misreporting fraud schemes increase the probability of the SEC charging the auditor as compared to the probability of being silent. Whereas the perpetrator's executive position decreases the probability of the SEC charging the auditor as compared to the probability of being silent. Overall, only a few fraud characteristics affect the 
SEC's finding regarding the auditor, which is not consistent with the current auditor accountability framework being an outcome-penalty framework. In contrast, the auditor type, being a Big $\mathrm{N}$ auditor or not, significantly affects the SEC's findings. More specifically, the results show that the SEC is more likely to remain silent or state that the fraud scheme is concealed for Bing $\mathrm{N}$ than non-Big-N auditor, as compared to charging the auditor. Given that Big-N auditors are found to provide better quality audits in prior studies, the findings are more consistent a process-reward accountability framework.

This study makes two important contributions. First, the findings of this study provide empirical insights into the discussion of whether the current regulatory system relies on audit outcomes or on attributes of auditors' judgment processes. The SEC's aim in issuing enforcements against the auditor is to improve audit quality by holding auditors accountable. The accountability framework, employed by the regulatory bodies in disciplining auditors, impacts audit quality. Second, the findings provide insights to auditors in managing risks in subsequently detected FRF. When auditors fail to supply high audit quality, they face serious consequences. It is important that auditors take additional steps, during audit procedures, to reduce the risks associated with highrisk clients that were not identified during the client acceptance process. Thus, in an attempt to minimize engagement risk, it is essential for auditors to understand what aspects of audit process would decrease their likelihood to be named as a defendant by the SEC.

There are several limitations to this study. First, very little is known about the SEC's enforcement process against the auditors. There exists the probability that fraud characteristic indicators, other than the ones examined in this study, affect the SEC's decision-making process, when examining the auditor's responsibility in failing to detect FRFs. Second, the sample in this study includes over 25 years of FRF from 1985 until 2012. Several economic, legal and social 
factors have changed during this period, while this study only controls for the passage of SOX Act. This limitation is partially addressed with a pre- and post-SOX comparison. Third, the cases where the SEC neither charges the auditor nor state that the fraud was concealed from them, is a catch all category. There are many potential explanations why the SEC does not make any statement regarding the auditor, which are not identify and control for in this study. AAERs/LRs do not have a standardized form for the information disclosed. Therefore, a silent finding might be a discretionary decision of the person drafting the AAERs/LRs. 


\section{References}

.U.S. Securities and Exchange Commission 2014; 2015; 2016 Agency Financial Report.

. U.S. Securities and Exchange Commission 2015. Agency Financial Report.

25 SEC Docket 21982.

AU Section 508: Reports on Audited Financial Statements.

Beasley, M. S., J. V. Carcello, and D. R. Hermanson. 1999. Fraudulent Financial Reporting: 1987 - 1997. Committee of Sponsoring Organizations of the Treadway Commission 1.

Beasley, M. S., J. V. Carcello, D. R. Hermanson, and T. L. Neal. 2010. Fraudulent Financial Reporting 1998 - 2007. Committee of Sponsoring Organizations of the Treadway Commission 2

- 2013. Analysis of Alleged Auditor Deficiencies in SEC Fraud Investigations; 19982010. Center for Audit Quality.

Bockus, K., and F. Gigler. 1998. A theory of auditor resignation. Journal of Accounting Research 36 (2):191 - 208.

Bonner, S. E., Z.-V. Palmrose, and S. M. Young. 1998a. Fraud type and Auditor litigation: An analysis of SEC Accounting and Auditing Enforcement Releases. The Accounting Review 73 (4):503 - 532.

-1998b. Fraud type and Auditor litigation: An analysis of SEC Accounting and Auditing Enforcement Releases. . The Accounting Review 73 (4):503 - 532.

Carcello, J. V., C. Hollingsworth, and S. A. Mastrolia. 2011. The effect of PCAOB inspections on Big 4 audit quality. Research in Accounting Regulation 23 (2):85-96.

Carcello, J. V., and A. L. Nagy. 2004. Audit Firm Tenure and Fraudulent Financial Reporting. AUDITING: A Journal of Practice \& Theory 23 (2):55-69.

Ceresney, A. 2013. Financial Reporting and Accounting Fraud. Speech at American Law Institute Continuing Legal Education, Washington, D.C., September 19. . 2016a. Speech. Keynote Address at Directors Forum, January 25. 2016b. SEC Enforcement Division's focus on Auditors and Auditing. Keynote Address at American Law Institute Conference on Accountants' Liability: Confronting Enforcement and Litigation Risks, September 22.

Coffee, J. C. J. 2004. Gatekeeper failure and reform: The challange of fashioning relevant reforms. Boston University Law Review 84:301 - 364.

Cornell, R. M., R. C. Warne, and M. M. Eining. 2009. The Use of Remedial Tactics in Negligence Litigation. Contemporary Accounting Research 26 (3):767-787.

Dechow, P. M., W. Ge, C. R. Larson, and R. G. Sloan. 2011. Predicting Material Accounting Misstatements*. Contemporary Accounting Research 28 (1):17-82.

Dechow, P. M., R. G. Sloan, and A. P. Sweeney. 1996. Causes and consequences of earnings manipulation: An analysis of firms subject to enforcement actions by the SEC. Contemporary Accounting Research 13 (1):1 - 36.

DeFond, M., and J. Zhang. 2014. A review of archival auditing research. Journal of Accounting and Economics 58 (2-3):275-326.

DeFond, M. L., J. R. Francis, and N. J. Hallman. 2016. Awareness of SEC Enforcement and Auditor reporting decisions. SSRN.

DeFond, M. L., J. R. Francis, and X. Hu. 2011. The geography of SEC enforcement and auditor reporting for financially distressed clients. SSRN.

Eutsler, J., E. B. Nickell, and S. W. G. Robb. 2016. Fraud Risk Awareness and the Likelihood of Audit Enforcement Action. Accounting Horizons 30 (3):379-392. 
Johnstone, K. M., and J. C. Bedard. 2003. Risk management in client acceptance decisions. The Accounting Review 78 (4): 1003 - 1025. 2004. Audit firm portofolio management decisions. Journal of Accounting Research 42 (4):659 - 690 .

Kadous, K., and M. Mercer. 2012. Can Reporting Norms Create a Safe Harbor? Jury Verdicts against Auditors under Precise and Imprecise Accounting Standards. The Accounting Review 87 (2):565-587.

Kaplan, S. E., and D. D. Williams. 2013. Do Going Concern Audit Reports Protect Auditors from Litigation? A Simultaneous Equations Approach. The Accounting Review 88 (1):199-232.

Karpoff, J. M., D. S. Lee, and G. S. Martin. 2008. The cost to firms of cooking the books. The Journal of Financial and Quantitative Analysis 43 (3):581 - 611.

Kedia, S., U. Khan, and S. Rajgopal. 2017. The SEC's Enforcement Record against Auditors. SSRN.

Peecher, M. E., I. Solomon, and K. T. Trotman. 2013. An accountability framework for financial statement auditors and related research questions. Accounting, Organizations and Society 38 (8):596-620.

Reffett, A. B. 2010. Can identifying and Investingating fraud risks increase auditors' liability? The Accounting Review 85 (6):2145 - 2167.

Rollins, T. P., and W. G. Bremser. 1997. The SEC's enforcement actions against auditors; an auditor repuation and institutional theory perspective. Critical Perspectives on Accounting 8:191 - 206.

SEC. 2013-207. SEC charges three auditors in continuing crackdown on violations or failures by gatekeepers. Press Release, September 30.

Shu, S. Z. 2000. Auditor resginations: clientele effects and legal liability. Journal of Accounting and Economics 29:173 - 205.

Weber, J., M. Willennborg, and J. Zhang. 2008. Does Auditor Reputation Matter The Case of KPMG Germany and ComROAD AG. Journal of Accounting Research 46 (4):941 - 972.

White, M. J. 2013. Remarks at the Securities Enforcement Forum, October 9.

- 2015. Maintaining high-quality, reliable financial reporting: A shared and weighty responsibility. Keynote address at AICPA National Conference, December 9. 
Appendix A

\begin{tabular}{lcc}
\hline Variable & Measurement & Data Source \\
\hline DV - Dependent Variable & \\
\hline SEC_FINDING & $\begin{array}{l}\text { It equals 0 if the SEC charges the auditor, 1 if the SEC remains } \\
\text { silent, and 2 if the SEC states that the fraud scheme is concealed } \\
\text { form auditor. }\end{array}$ & $\begin{array}{c}\text { Dechow dataset/IFP } \\
\text { dataset/Hand } \\
\text { collection }\end{array}$
\end{tabular}

\begin{tabular}{|c|c|c|}
\hline \multicolumn{3}{|c|}{ IV- Fraud Characteristics } \\
\hline $\begin{array}{l}\text { Fraud Duration } \\
\text { (FR_DURATION) }\end{array}$ & $\begin{array}{l}\text { The number of quarterly financial statements affected by the } \\
\text { misstatement. }\end{array}$ & Dechow dataset \\
\hline $\begin{array}{l}\text { Fraud Amount } \\
\text { (FR_AMOUNT) }\end{array}$ & $\begin{array}{l}\text { Natural logarithm of the total dollar value of the amount of } \\
\text { assets that was misappropriated, or the amount of loss caused. }\end{array}$ & IFP dataset \\
\hline $\begin{array}{l}\text { Collusion } \\
\text { (COLLUSION) }\end{array}$ & $\begin{array}{l}\text { The number of perpetrators involved in the fraud scheme } \\
\text { calculated as the sum of three separate indicator variables. }\end{array}$ & IFP dataset \\
\hline $\begin{array}{l}\text { Fraud Type } \\
\text { (REVFraud) }\end{array}$ & $\begin{array}{l}\text { Indicator variable equals to } 1 \text { if the fraud scheme involved } \\
\text { revenue misreporting, and } 0 \text { otherwise. }\end{array}$ & Dechow dataset \\
\hline $\begin{array}{l}\text { Fraud Type } \\
\text { (AMFraud) }\end{array}$ & $\begin{array}{l}\text { Indicator variable equals to } 1 \text { if the fraud scheme involved asset } \\
\text { misreporting, and } 0 \text { otherwise. }\end{array}$ & Dechow dataset \\
\hline $\begin{array}{l}\text { Fraud Type } \\
\text { (DISCFraud) }\end{array}$ & $\begin{array}{l}\text { Indicator variable equals to } 1 \text { if the fraud scheme involved } \\
\text { failure to disclose material information, and } 0 \text { otherwise. }\end{array}$ & IFP dataset \\
\hline $\begin{array}{l}\text { Perpetrator Position } \\
\text { (PERP_POSITION) }\end{array}$ & $\begin{array}{l}\text { Indicator variable equals to } 1 \text { if the perpetrator is the CEO, } \\
\mathrm{COO} \text { or the president of the fraudulent firm, and } 0 \text { otherwise. }\end{array}$ & IFP dataset \\
\hline \multicolumn{3}{|c|}{ CV - Control Variables } \\
\hline $\begin{array}{l}\text { Firm Size } \\
\text { (FIRM_SIZE) }\end{array}$ & $\begin{array}{l}\text { The ratio of total revenues over the total assets on the year prior } \\
\text { to the first misreported year or year prior to that in cases where } \\
\text { data was missing. }\end{array}$ & Compustat dataset \\
\hline $\begin{array}{l}\text { Audit Tenure } \\
\text { (AUDIT_TENURE) }\end{array}$ & $\begin{array}{l}\text { The number of consecutive years an auditor audited the same } \\
\text { client until the last year of the fraud duration. }\end{array}$ & $\begin{array}{l}\text { Audit Analytics } \\
\text { dataset }\end{array}$ \\
\hline $\begin{array}{l}\text { Going Concern } \\
\text { (GC) }\end{array}$ & $\begin{array}{l}\text { Indicator variable equals to } 1 \text { if the auditor issued a going } \\
\text { concern, and } 0 \text { otherwise. }\end{array}$ & $\begin{array}{l}\text { Audit Analytics } \\
\text { dataset }\end{array}$ \\
\hline $\begin{array}{l}\text { Auditor Type } \\
(\text { BIG-N) }\end{array}$ & $\begin{array}{l}\text { Indicator variable equals to } 1 \text { if the auditor is one of the Big } 4 \\
\text { firms, i.e. PricewaterhouseCoopers LLP, Ernst \& Young LLP, } \\
\text { KPMG LLP and Deloitte \& Touche LLP, or Arthur Andersen } \\
\text { LLP, and } 0 \text { otherwise }\end{array}$ & $\begin{array}{l}\text { Audit Analytics } \\
\text { dataset }\end{array}$ \\
\hline
\end{tabular}




\begin{tabular}{llc}
\hline Variable & \multicolumn{1}{c}{ Measurement } & Data Source \\
\hline $\begin{array}{l}\text { Sarbanes-Oxley Act } \\
\text { (SOX) }\end{array}$ & $\begin{array}{l}\text { Indicator variable, where it equals 1 if the fraud scheme } \\
\text { terminated after 2002, and 0 otherwise. }\end{array}$ & Dechow dataset \\
\hline
\end{tabular}


Figure 3 - 1: Illustration of an AAER

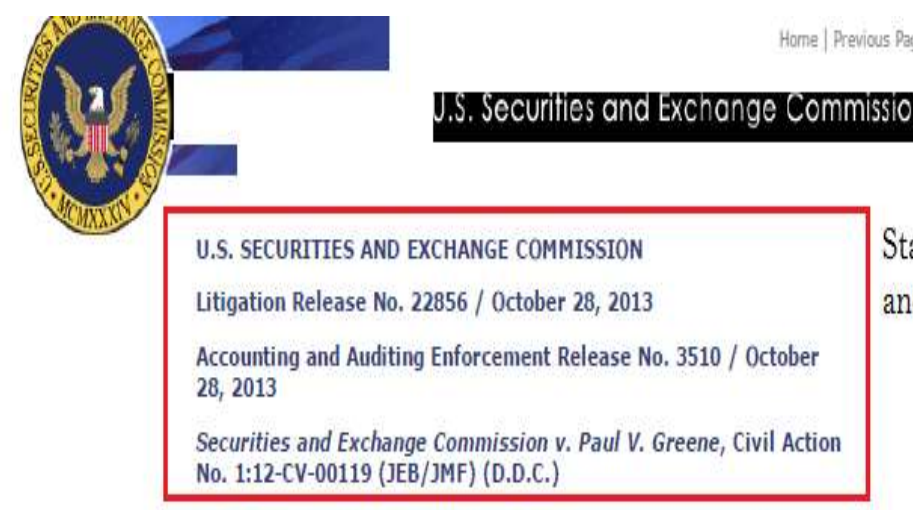

Standard information about the AAER no. and the title of the AAER.

SEC Obtains Permanent Injunction and $\$ 100,000$ Civil Penalty Against Cellular Telephone Company President for Role in Fraudulent Scheme

The Securities and Exchange Commission today announced that on October 24, 2013, the Honorable James E. Boasberg, United States District Judge for the District of Columbia, entered a final judgment against defendant Paul V. Greene, President of privately-held Americas Premiere Corporation $(A P C)$, a former vendor of InPhonic, Inc. (InPhonic), a now-bankrupt online retailer of cellular phones. The final judgment permanently enjoins Greene from violating the antifraud, books and records and reporting provisions of the securities laws and orders him to pay a $\$ 100,000$ penalty.

According to the comminssion's complaint, starting in the whind quarter of 2005, and reach quarter of 2006, Greene and Len A. Famiant, thng an InDhic Senior Vice President, engaged in a series of undisclosed "roul p transactions to heip ininhonic artificially inflate its financial results. After the end of the quarters, but before InPhonic publically reported its financial results, Familant obtained APC credits from Greene. At the same time, however, Familant and Greene entered into an oral side agreement under which InPhonic would repay the credits through future purchases of certain cell phone models at inflated prices and by paying for inflated and fake repairs. The complaint further alleges Greene hid the scheme from InPhonic's independent auditors even after APC's accountant had informed Greene that APC's sham credit transactions with InPhonic were illegal. InPhonic improperly recorded a total of almost $\$ 10$ million in credits from YPC as a decrease in cost of goods sold, which allowed inphonic to materially understate its losses and meet its quarterly and annual finang targets tweports filed with the Commission. A final judgment a defendant Lentrenilant was previously entered by the Cou

Without admitting or denying the allegations in the Commission's complaint, Greene consented to the entry of the final judgment permanently enjoining him from violating the antifraud provisions, Section 10 (b) of the Exchange Act and Exchange Act Rule 10b-5(a) and (c), and books and records provision, Exchange Act Rule 13b2-1, and aiding and abetting violations of Section 10(b) of the Exchange Act and Exchange Act Rule 10b-5(a) and (c), books and records provision, Section 13(b)(2)(A) of the Exchange Act, and reporting provisions, Section 13(a) of the Exchange Act and Exchange Act Rules $12 b-20,13 a-1,13 a-11$ and $13 a-13$, and ordering him to pay a $\$ 100,000$ civil penalty.

For further information, please see Litigation Release №. 22237 (January 25, 2012).

Information about the judge, the district, the entity or individual being charged Penalties enforced against the charged
entities or individuals.
Description of the fraud scheme and its characteristics. 


\section{Figure 3 - 2: Illustration of an LR}

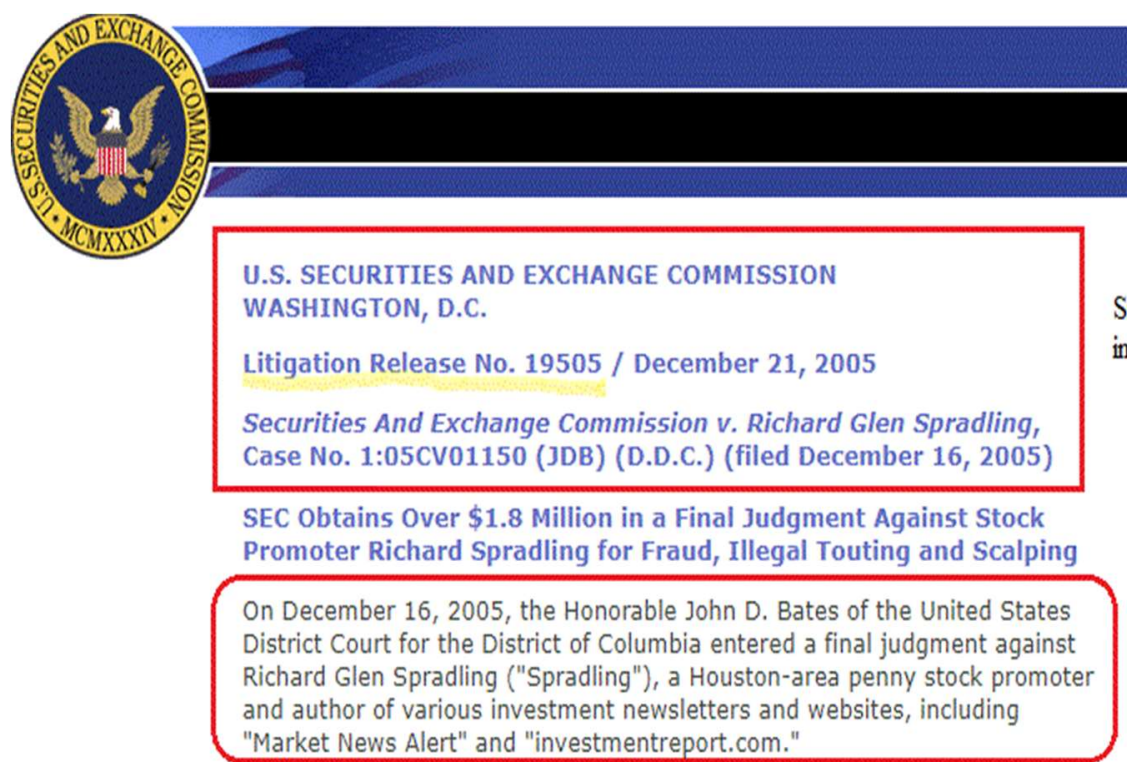

Standard indentificantion information about the LR.

Information about the judge, the district and the charged entity or individual/s.

In its Complaint, the commission alleged that, through his newsletters and websites, Spradthrg illegally touted stocks without adequately disclosing the amount and nature of his compensation. In fact, Spradling's compensation most fen came from the very companies he promoted or persons aspociated with the companies that he promoted. The Complaint also Aleged that Spradling "scalped" stocks he promoted by selling into the demand that his newsletters and website promotions created. Specifically, the Commission's Complaint alleged that between April 2001 and September 2003, Spradling promoted more than 44 penny stock issues by faxing newsletters to hundreds of thousands of individuals. The Complaint further alleged that Spradling received compensation in the form of stock for at least 36 of the penny stocks he promoted and that he sold at least 32 of the stocks during the promotion of the stock. By his conduct, Spradling yielded net proceeds of over $\$ 1.6$ million. In addition, the Commission alleged in the Complaint that Spradling falsely stated that "Market News A prodyction and dissemination of each newsletter was paid for by the zubject compahy or a related promoter and Spradling's newsletter had nopaid subscribers. The Complaint also alleged that Spradling dissepmated fraudulent annuatravenues and revenue forecasts op behalf of at least one company.

The Final Judgment permanently enjoins Spradling from violating Section 17 (b) of the Securities Act of 1933, Section 10(b) of the Securities Exchange Act of 1934, and Rule 10b-5 thereunder. In addition, the Final Judgment orders Spradling to pay $\$ 1,893,075.83$, comprised of $\$ 1.6$ million in disgorgement, $\$ 173,075.83$ in prejudgment interest thereon, and a $\$ 120,000$ civil penalty for Spradling's violations of the federal securities laws. The Final Judgment also permanently barred Spradling from participating in any offering of penny stocks.

Additional information concerning the Commission's civil enforcement action against Spradling can be found in Litigation Release No. 19263 (June 9, 2005).

Information on violated nules and penalities enforced.
Further information is provided in prior issued LRs 
Table 3 - 1: Studies Examining SEC Enforcements Against the Independent Auditor.

\begin{tabular}{|c|c|c|c|c|c|c|}
\hline STUDY & \begin{tabular}{|c|}
\multicolumn{1}{|c|}{$\mathbf{D V}$} \\
$(1=$ Aud. Charged $;$ \\
$0=$ Otherwise $)$
\end{tabular} & IV & $\mathrm{CV}$ & SAMPLE & $\begin{array}{l}\text { SAMPLE } \\
\text { PERIOD }\end{array}$ & $\begin{array}{c}\text { OBSERVED } \\
\text { ASSOCIATION }\end{array}$ \\
\hline $\begin{array}{l}\text { Kedia, } \\
\text { Khan } \\
\text { and } \\
\text { Rajgopal } \\
\text { (2017) }\end{array}$ & $\begin{array}{l}\text { Auditor_Na } \\
\text { med }\end{array}$ & $\begin{array}{l}\text { Big N (Binary } \\
\text { Variable: } 1= \\
\text { Big } N \text { auditor; } \\
0=\text { Otherwise) }\end{array}$ & $\begin{array}{l}\text { Post SOX; Severity Violation: } \\
\text { VIOLENGTH, TARGET_LIT, } \\
\text { TARGET_RESTATE, } \\
\text { TARGET_COURT; Firm } \\
\text { Characteristics: SIZE, } \\
\text { SALES/AT, CA/CL, DEBT/AT, } \\
\text { NI/AT. }\end{array}$ & $\begin{array}{l}533 \text { SEC } \\
\text { enforcements; } 93 \\
\text { cases included } \\
\text { enforcement } \\
\text { against auditors. }\end{array}$ & $\begin{array}{l}1996- \\
2009\end{array}$ & $\begin{array}{l}\text { SEC is less likely to name a Big } \\
\mathrm{N} \text { auditor as a defendant, and to } \\
\text { impose harsh penalties on } \\
\text { them. Overall, SEC relies more } \\
\text { on administrative proceedings } \\
\text { than tougher civil proceedings, } \\
\text { against auditors. }\end{array}$ \\
\hline $\begin{array}{l}\text { Eutsler, } \\
\text { Nickell } \\
\text { and } \\
\text { Robb } \\
(2016)\end{array}$ & AUDAAER & $\begin{array}{l}\text { GCO (Binary } \\
\text { Variable: } 1= \\
\text { auditor issued } \\
\text { a GC opinion; } \\
0=\text { otherwise) }\end{array}$ & $\begin{array}{l}\text { Firm Characteristics: Size, } \\
\text { Bankruptcy, FOREIGN, } \\
\text { ZSCORE, REC_INV, } \\
\text { INDTECH, INDFIN, INDUTIL; } \\
\text { Fraud Characteristics: } \\
\text { FRUADTEN, REVENUE; } \\
\text { DISCLOSE, MISSTATE; } \\
\text { Auditor Characteristics: BIGN, } \\
\text { AUDTEN. }\end{array}$ & $\begin{array}{l}314 \text { fraud cases; } \\
54 \text { included } \\
\text { enforcement } \\
\text { against auditor; } \\
34 \text { included a GC; } \\
12 \text { included both } \\
\text { an enforcement } \\
\text { against the } \\
\text { auditor and a GC. }\end{array}$ & $\begin{array}{l}1995- \\
2012\end{array}$ & $\begin{array}{l}\text { GC report modification } \\
\text { accompanying the last set of } \\
\text { fraudulently stated financials } \\
\text { are associated with a greater } \\
\text { likelihood of enforcement } \\
\text { action against the auditor. } \\
\text { Auditors may be penalized for } \\
\text { documenting their awareness of } \\
\text { fraud risk when FS are later } \\
\text { determined to be fraudulent. }\end{array}$ \\
\hline $\begin{array}{l}\text { Rollins } \\
\text { and } \\
\text { Bremser } \\
\text { (1997) }\end{array}$ & SEC_DIS & $\begin{array}{l}\text { AUD_CLASS: } \\
\text { auditor's size; } \\
\text { DIV (Binary } \\
\text { Variable: } 1= \\
\text { auditor is } \\
\text { AICPA; } 0= \\
\text { otherwise) }\end{array}$ & $\begin{array}{l}\text { Violation Type: FALSIFY, } \\
\text { AR_OVER, DISCL. }\end{array}$ & $\begin{array}{l}91 \text { enforcement } \\
\text { cases; } 33 \text { cases } \\
\text { included } \\
\text { enforcement } \\
\text { against the } \\
\text { auditor. }\end{array}$ & $1982-1991$ & $\begin{array}{l}\text { Larger auditors and auditors } \\
\text { who were members of the } \\
\text { AICPA Division for CPA } \\
\text { Firms had a lower likelihood of } \\
\text { SEC sanctions. Also, disclosure } \\
\text { violation increased the } \\
\text { likelihood }\end{array}$ \\
\hline
\end{tabular}


Table 3 - 2: Descriptive Statistics for Full Sample and by SEC's Auditor Related Findings

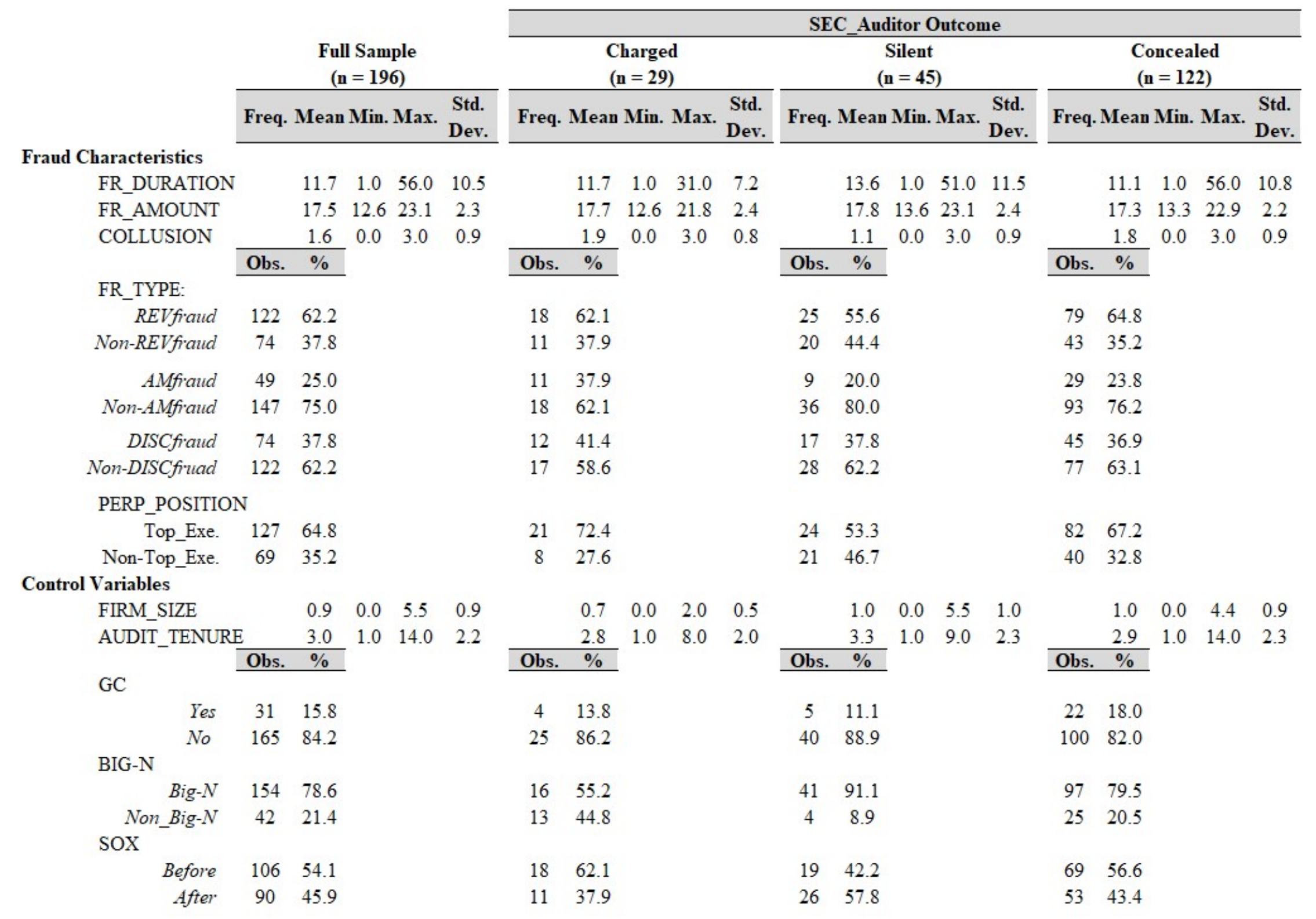




\section{Variable Definitions:}

FR_DURATION = the number of quarterly financial statements misreported by the fraudulent firm;

FR_AMOUNT = natural logarithm of the total misreported amount or total misappropriated assets;

COLLUSION $=$ number of perpetrators involved in the fraud scheme;

FR_TYPE $=$ three separate indicator variable equal to 1 if the fraud scheme involved misreporting of revues, assets or fail to disclose relevant information in the financial statements, and 0 otherwise.

PERP_POSITION = indicator variable where it is equal to 1 if the perpetrator is the CEO, COO or the president of the fraudulent firm and 0 otherwise.

FIRM_SIZE = measure as the ratio of total revenues over the total assets on the year prior to the first misreported year or year prior to that in cases where data was missing.

AUDIT_TENURE $=$ the number of consecutive years an auditor audited the same client until the last year of the fraud duration.

$\mathrm{GC}=$ indicator variable, where it equals 1 if the auditor issued a going concern in the audit report, and 0 otherwise.

BIG-N = indicator variable, where it equals 1 if independent auditor is part of the Big 4 firms, i.e. PricewaterhouseCoopers LLP, Ernst \& Young LLP, KPMG LLP and Deloitte \& Touche LLP, and also Arthur Andersen LLP, and 0 otherwise

$\mathrm{SOX}=$ indicator variable, where it equals 1 the fraud scheme ended after the issuance of SOX, and 0 otherwise. 
Table 3 - 3: Pearson Correlation Coefficients

$$
(n=196)
$$

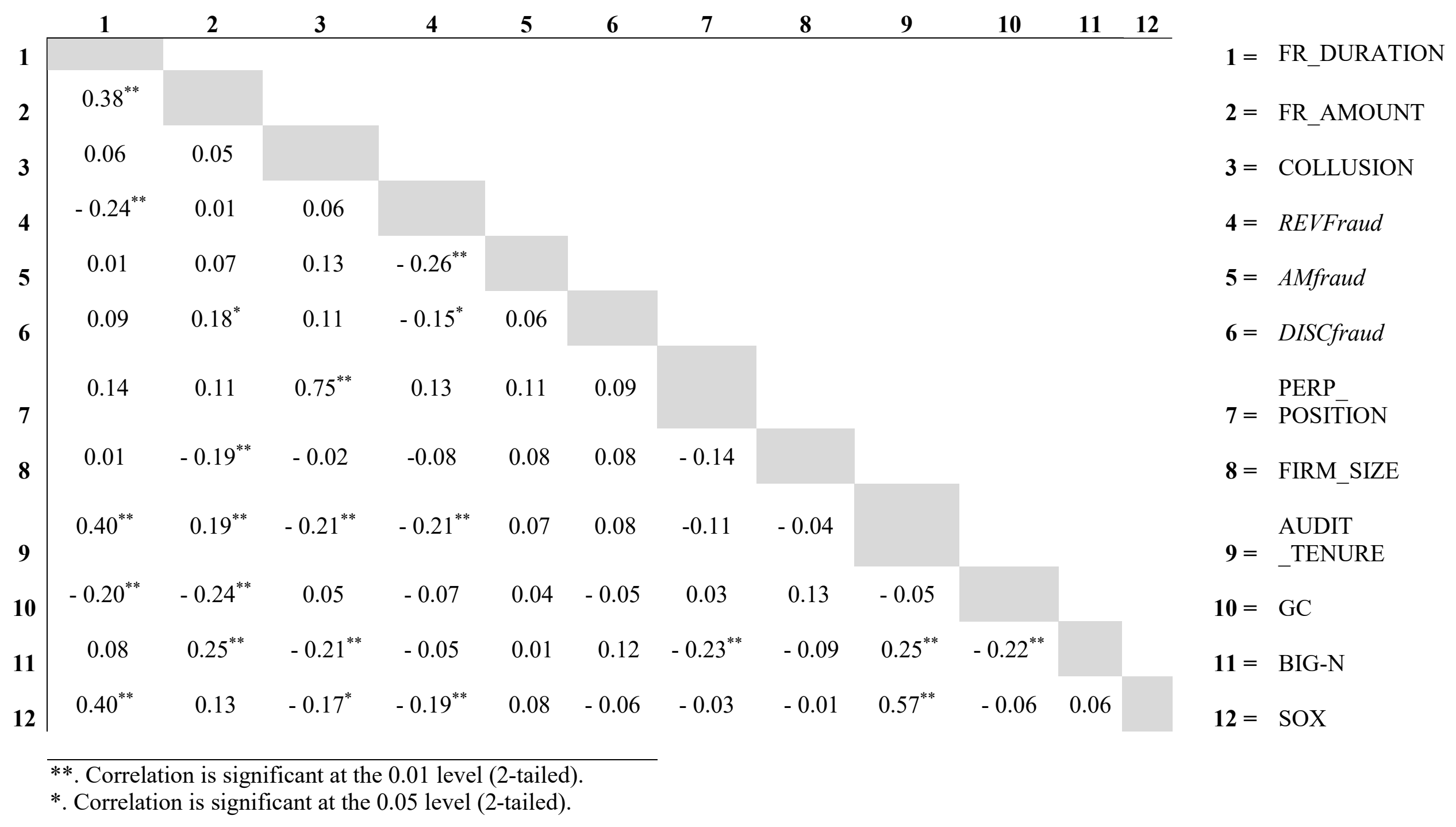

Variables are defined in Table 3 - 1 and Appendix A. 
Table 3 - 4: Multinomial Logit Regression - SEC's Auditor Related Findings and Fraud Characteristics.

$$
(\mathrm{n}=196)
$$

\begin{tabular}{|c|c|c|c|c|c|c|c|c|c|c|}
\hline \multirow[b]{2}{*}{ Variables } & \multicolumn{5}{|c|}{ Silent } & \multicolumn{5}{|c|}{ Concealed } \\
\hline & $\mathbf{B}^{\mathbf{a}}$ & $\mathbf{S E}^{\mathbf{b}}$ & $\mathbf{O R}^{\mathrm{c}}$ & $95 \% \mathrm{Cl}$ & & $\mathbf{B}^{\mathbf{a}}$ & $\mathbf{S E}^{\mathbf{b}}$ & OR $^{c}$ & $95^{\circ}$ & $\mathrm{CI}^{\mathrm{d}}$ \\
\hline \multirow{2}{*}{\multicolumn{11}{|c|}{ Fraud severity }} \\
\hline & & & & & & & & & & \\
\hline FR_DURATION & 0.01 & 0.03 & 1.01 & {$[0.95$,} & $1.07]$ & 0.00 & 0.03 & 1.00 & {$[0.95$,} & $1.05]$ \\
\hline FR_AMOUNT & -0.07 & 0.14 & 0.93 & {$[0.71$,} & $1.22]$ & -0.15 & 0.12 & 0.86 & {$[0.68$,} & $1.08]$ \\
\hline COLLUSION & -1.77 & $0.50 * * *$ & 0.17 & {$[0.06$} & $0.46]$ & -0.14 & 0.40 & 0.87 & {$[0.40$,} & $1.91]$ \\
\hline \multicolumn{11}{|l|}{ FR_TYPE: } \\
\hline REVfraud & -0.43 & 0.62 & 0.65 & {$[0.19$,} & $2.20]$ & 0.12 & 0.52 & 1.13 & {$[0.41$,} & $3.16]$ \\
\hline AMfraud & -1.20 & $0.66^{* *}$ & 0.30 & {$[0.08$,} & $1.08]$ & -0.83 & $0.50 *$ & 0.44 & {$[0.16$,} & $1.15]$ \\
\hline DISCfraud & -0.20 & 0.58 & 0.82 & {$[0.26$,} & $2.57]$ & -0.17 & 0.48 & 0.85 & {$[0.33$,} & $2.16]$ \\
\hline PERP_POSITION (Top_Exe.) & 2.42 & $0.95 * *$ & 11.26 & {$[1.76$} & 71.98] & 0.69 & 0.80 & 1.99 & {$[0.42$,} & $9.44]$ \\
\hline \multicolumn{11}{|l|}{ Control Variables } \\
\hline FIRM_SIZE & 0.71 & $0.37^{*}$ & 2.04 & {$[1.00$} & $4.18]$ & 0.47 & 0.30 & 1.60 & {$[0.88$,} & 2.90] \\
\hline AUDIT_TENURE & -0.20 & 0.15 & 0.81 & {$[0.61$,} & $1.09]$ & -0.06 & 0.12 & 0.94 & {$[0.74$} & $1.20]$ \\
\hline GC & 0.41 & 0.88 & 1.51 & {$[0.27$} & $8.52]$ & 0.66 & 0.70 & 1.94 & {$[0.49$, } & 7.64] \\
\hline BIG-N & 2.96 & $0.82 * * *$ & 19.21 & {$[3.88$,} & 95.04] & 1.87 & $0.56 * * *$ & 6.47 & {$[2.14$,} & 19.58] \\
\hline SOX & 0.98 & 0.70 & 2.65 & {$[0.68$,} & $10.42]$ & 0.52 & 0.58 & 1.69 & {$[0.54$,} & $5.31]$ \\
\hline
\end{tabular}

$*, * *, * * *$ Indicate $\mathrm{p}<0.1, \mathrm{p}<0.05$, and $\mathrm{p}<0.01$ levels, respectively, for two-tailed test.

${ }^{\mathrm{a}}$ regression coefficient, ${ }^{\mathrm{b}}$ standard error, ${ }^{\mathrm{c}}$ odds ratio and ${ }^{\mathrm{d}}$ confidence interval. 


\title{
CHAPTER FOUR: FRAUD VICTIM ORGANIZATION: TO PUNISH, OR NOT TO PUNISH? THAT IS THE QUESTION.
}

\author{
Erlina Papakroni* \\ John Chambers College of Business and Economics, West Virginia University \\ epapakro@mix.wvu.edu \\ Marie Rice \\ John Chambers College of Business and Economics, West Virginia University \\ mmr0016@mix.wvu.edu
}




\subsection{INTRODUCTION}

When high-profile fraud cases were detected in the early 2000s, many victim organizations rushed to replace their top executives. Some executives resigned voluntarily while others were terminated. For instance, Enron's CEO, Jeffrey Skilling had resigned in August 2001, a few months before accounting manipulations were revealed to the public. WorldCom's CEO, Bernard Ebbers, resigned right after the fraudulent scheme had become public, and CFO, Scott Sullivan, was terminated at the same time. HealthSouth's CEO, Richard Scrushy, and CFO, Weston Smith, were terminated weeks after the fraud scheme had become public information. At the same time, there were many other victim organizations, such as First USA Inc., 3COM, Boston Scientific, and Bausch and Lomb that did not terminate their CEOs or CFOs after the detection of accounting scandals (Agrawal and Cooper 2017).

Organizations, the victims of occupational fraud, choose whether and how to punish perpetrators involved in fraud schemes. The purpose of this study is to examine the factors that are associated with the victim organization's decision to pursue a particular outcome against the principal perpetrator. Prior research has shown that crime severity is positively related to outcome severity and that this relationship is moderated by the perpetrator's characteristics (Albonetti 1998; Wheeler, Weisburd, Waring and Bode 1988; Hagan and Parker 1985). The outcomes of whitecollar crime cases, such as occupational frauds, are often situation-specific (Holtfreter, Piquero and Piquero 2008b) and vary by the victim and perpetrator characteristics (Agrawal and Cooper 2017; Beneish 1999; Garrett 2015; Hermanson, Justice, Ramamoorti and Riley 2017; Holtfreter 2005; Karpoff et al. 2008). Victim organizations determine which outcomes to pursue against the perpetrators, considering the facts and circumstances of the case, such as the severity of the fraud and the perpetrator's status. Further, victim organizations need to consider the cost-benefit of 
deterrence measures (Rae and Subramanian 2008), such as physical and monitoring controls (Townsley and Birks 2008), and how the organizational type affects the punishment pursued (Beneish, Marshall and Yang 2017). Punishment outcomes, such as termination and/or criminal prosecution, may generate short-term or long-term costs to the organization and may impact the level of scrutiny that the victim organization faces from outside stakeholders (Holtfreter 2008a; Dugan and Gibbs 2009). Thus, in addition to fraud severity and the perpetrator's status, different types of organizations pursue different outcomes, based on a cost-benefit analysis.

We use General Crime Theory and Status Characteristics Theory to examine the impact of fraud severity, the perpetrator's status, and the organization type on the victim organization's decision to pursue an outcome against the principal perpetrator. The first part of our study examines the main effects of these three factors on the outcome pursued, whereas the second part of the study explores how the perpetrator's status or organization type interact with the association of severity and outcome severity in occupational fraud cases. To our knowledge, no prior study has examined these interactions in an occupational fraud setting.

We use the occupational fraud data obtained from the Institute for Fraud Prevention (IFP). The data are collected by the Association of Certified Fraud Examiners (ACFE) through a biennial survey of Certified Fraud Examiners (CFEs). The sample in our study includes fraud cases investigated from the beginning of 2002 until October 2015. Survey participants responded to 80 questions on their largest occupational fraud case investigation completed within two years prior to the survey date. Our final sample consists of 2,096 fraud cases. The principal perpetrator does not face any outcome in 217 fraud cases (10.4 percent), is terminated in 535 fraud cases (25.5 percent), and is both terminated and criminally prosecuted in 1,344 fraud cases (64.1 percent). In most fraud cases, the principal perpetrator faces harsh consequences by losing their employment 
and facing criminal prosecution. Yet, in over 10 percent of the cases, the victim organization decides to neither terminate the principal perpetrator nor to file any charges against him/her. According to the ACFE survey, 88.7 percent of the fraud cases reported involve asset misappropriation (11.3 percent are non-AM), which last for an average of 25.6 and are committed by an average of 2.4 individuals.

We use multinomial logistic regression to examine the moderating effects of the perpetrator status or the type of organization on the association between the occupational fraud outcome pursued by victim organizations and the attributes of the fraud scheme. We find that as fraud severity increases, the severity of the outcome pursued against the principal perpetrator increases as well. However, victim organizations pursue less severe outcomes against high status perpetrators, as compared to low status perpetrators in fraud cases with a short duration. As the fraud duration increases, however, victim organizations pursue equally severe outcomes against all perpetrators. Lastly, governmental, not-for-profit, and privately held organizations are more likely to pursue no outcome against principal perpetrators as compared to publicly traded organizations. However, governmental and not-for-profit organizations are more likely to terminate and criminally prosecute the principal perpetrators, pursuing harsher outcomes. We conclude that the fraud outcome is determined not only by the severity of the fraud act, but also by the status of the perpetrator who committed the fraud and the type of the victim organization.

These findings matter to CFEs, organizational leaders, and the anti-fraud profession. CFEs and organizational leaders designing and implementing anti-fraud controls often refer to the ACFE's Report to the Nations (2018) for the descriptive statistics of current occupational fraud trends to monitor who commits occupational fraud, where, and how. During their work, CFEs are often engaged to oversee fraud examinations on behalf of organizations, including advising which 
outcome to pursue, given the facts and circumstances of the case. CFEs advising clients on fraud examinations benefit from considering these inputs and their interactions when helping clients select an appropriate outcome. This study adds context to the ACFE's Report to the Nations (2018), which serves the anti-fraud profession, by showing interactions between the occupational fraud characteristics, the perpetrator's status, and the punishment selected.

This study also enhances researchers' understanding of victim organizations' reactions to fraudulent instances. Enforcement agencies, regulators, investors, and other stakeholders may also benefit from the results of our study when they consider pursuing outcomes against individual or organizational perpetrators. Our findings extend the application of general crime theory to a specific type of white-collar crimes (i.e. occupational fraud). By being first to examine the interaction of fraud severity, the perpetrator's status, and the victim organization type, we also generate ideas for a potential extension and future fraud research.

The rest of the paper is organized as follows: Section 2 provides a review of general crime theory, developed in criminology literature, and its application in white-collar crime literature. It also develops the hypotheses about the main effects and the interaction effects of fraud severity, the perpetrator's status, and the organization type on outcome severity. Section 3 describes the sample and the empirical model used in this study. Section 4 presents the results, and section 5 concludes this study. 


\subsection{THEORETICAL BACKGROUND AND HYPOTHESIS DEVELOPMENT}

\subsection{General Crime Theory}

General crime theory argues that punishment for wrongdoing provides recompense or retribution for the victim and society (Retributive Theory), acts as a deterrence against future offense (Deterrence/Utilitarian Theory), and reforms the criminal (Reformative Theory) (Green 1999; Skoczylis 2008; Bedau 1978; Hart 1959). Retributive, deterrence, and reformative theories provide general guidance on punishment. Specifically, retributive theory explains that punishment severity should be related to crime severity (Bedau 1978) while deterrence theory suggests that punishment types yield varying costs and benefits to the society, the victim, and the perpetrator (Carlsmith, Darley and Robinson 2002). Finally, reformative theory emphasizes the need to not only correct the current behavior, but also reform the criminal to prevent future wrongdoing (Sabbagh and Schmitt 2016). Figure 4 - 1 shows a diagram of general crime theory and its underlying theories.

General crime theory provides a broad view of crime and punishment as well as recompense for actions at the societal level; it does not, however, consider individual facts and circumstances of the related cases. Cahill (2007) addresses this issue in his decomposition of retributive theory into three ways criminals receive "just deserts" for their wrongdoing (also known as the principle of proportionality): the absolutionist view, the threshold view, and the consequentialist view. The absolutionist model states that every crime should have a commensurate penalty, regardless of external circumstances. Similarly, Cahill (2007) explains that the threshold model argues that the deviation from the "just deserts" principle should be avoided when possible and assigned in an ordinal manner when not possible so that the most serious crimes are dealt with first. The consequentialist view, however, seeks to find a balance between punishing the most crimes (absolutionist) and punishing the severest crimes (threshold) by considering the 
costs of the apprehension and the severity of the offense before administering the consequences for the crimes (Cahill 2007).

[Insert Figure 4-1 here]

These theories hold across disciplines and have been cited in philosophy, sociology, criminology, and criminal justice literature (Carlsmith 2008; Gromet and Darley 2009; Carlsmith et al. 2002) as they provide context with which to measure punishment.

\subsection{Status Characteristics Theory}

Status characteristics theory (SCT) describes the perceptions one forms when encountering another based on the second person's age, race, gender, and/or position that guide the first person's beliefs about the second person's capabilities (Berger, Cohen and Zelditch 1971). Berger et al. (1971) define a status characteristic as "a characteristic that is differentially evaluated and implies possession of other characteristics" (p.3) and a diffuse status characteristic as one that produces general assumptions about the second person. First impressions of others are often based on status characteristics as "attributes of appearance that are easily observed (i.e. do not require close inspection) and show clear differences among interactants" (Ridgeway 1991, p.372). Status characteristics also capture beliefs and perceptions about a target individual's influence over decisions (Berger et al. 1971) that are developed through interpersonal interactions (Ridgeway 1991). During these interactions, individuals form schemas, or mental descriptions, of each other that categorize traits and behavioral profiles (Ridgeway 2001) related to the perceived position or authority. It is important to note that these schemas or beliefs about another's competency need not be accurate or correct to influence interactions. For instance, status research consistently finds that men, whites, the middle aged, those who are highly educated, and those who are physically 
attractive are associated with greater expectations of ability even if this is not objectively the case (Berger and Webster 2006).

In the workplace, status characteristics may include the target's physical features as well as their position within the company. The position within the company is correlated with the individual's education, tenure, and age and is the most salient of these status characteristics. Webster and Driskell (1978) explain that when a target possesses multiple status characteristics, the most salient characteristic to the domain determines the perceptions others have of his/her abilities and influence over decisions. Therefore, the perceived influence one has over others in the workplace is derived from a combination of his/her status characteristics, with an emphasis on the position within the company.

SCT explains how the perceived seriousness of an occupational (i.e. workplace) fraud, and therefore related punishment, may differ between perpetrators. Specifically, the evaluator may believe a perpetrator should have a harsher or more lenient punishment, depending on perceived status characteristics. Prior literature shows that perpetrators with different statuses receive different levels of punishment, even when the crimes are similar in severity. Eitle (2000) finds that the position within the victim organization influences the punitive response. For example, Garrett (2015) finds that management-level offenders are more frequently penalized than their executivelevel counterparts. Dilks, McGrimmon and Thye (2015) examines accumulative differences in diffuse and specific status characteristics between criminals and offenders, finding that the higher the offenders' status in relation to the victim, the less serious their crime is perceived to be. Likewise, Weisburd, Waring and Wheeler (1990) find that officers are less likely to be imprisoned for white-collar crimes than workers or managers. Longer jail sentences are also noted by Gottschalk (2012) for lower status white-collar criminals, when comparing fraud to other types of 
white-collar crimes. Thus, while status characteristics describe the perceived ability and influence an individual has, evaluators also consider status characteristics in judgement decisions.

In fact, extant literature finds that the status variance among occupational fraudsters indeed affects the punishment that they face due to the influence that higher status individuals have on others and the opportunities they are afforded. Rosenmerkel (2001) finds that some of the respondent's characteristics, such as "age, gender, and SES have a slight effect" (p. 320) on the relationship between crime severity and punishment severity. In a study of federal white-collar crime cases in seven separate districts, Albonetti (1998) explains that the perpetrator's characteristics have a significant direct effect on the severity of the assigned punishment. Opportunities available for occupational fraud via the perpetrator's position further affect the consequences that the perpetrators experience (Hagan and Parker 1985). Davis and Pesch (2013) find that the "social influence of the individuals" (p. 481) in an organization also affects the likelihood of fraud. Whether there is a negative or positive association between the perpetrator's status and punishment severity, these prior studies show that the differences in the perpetrators' positions create different perceptions of the perpetrators' abilities and influence, in part because of the opportunities that the perpetrators have to engage in fraud, which results in varying punishments.

\subsection{Hypothesis Development}

\subsubsection{Outcome severity, fraud severity, the perpetrator's status, and the organization type}

Retributive theory is the form of general crime theory that explains the relationship between punishment and crime and states that punishment severity should be related to crime severity (Bedau 1978). The consequentialist view of retributive theory considers the costs of the apprehension and the severity of the offense before administering the consequences for the crimes 
(Cahill 2007). It provides a rich context for the administration of justice by going beyond the issuance of punishment for the sake of recompense and considering the "micro-analytic and context sensitive" (Fondacaro and O'Toole 2015) components of the crime. The consequentialist view also assimilates deterrence for the individual criminal through censure or shame (Von Hirsch 1992).

The consequentialist view of retributive theory fits white-collar crimes because of its consideration of the facts and circumstances of the crime, such as the perpetrator's motive and opportunities (Benson and Moore 1992; Coleman 1987), to commit and conceal their offenses. One type of white-collar crimes is occupational fraud, classified by the ACFE as asset misappropriation, corruption, and financial statement fraud (ACFE 2018). Following the consequentialist view of retributive theory, occupational fraud punishments vary by the facts and circumstances of each case (Holtfreter et al. 2008; Rossi et al. 1985).

Prior literature has shown that termination rates, criminal sentences, and the likelihood of civil remedies differ based on crime types (a proxy for crime severity), the perpetrator's characteristics (Agrawal and Cooper 2017; Garrett 2015; Karpoff et al. 2008b), and the victim organization's characteristics. Prior literature also argues that a positive relationship exists between crime severity and punishment severity (Wheeler, et al. 1988; Weisburd et al. 1990; Tillman and Pontell 1992; Hagan and Parker 1985). Separately, extant literature shows that the status advantage of a perpetrator becomes a liability for the received punishment. McGrimmon, Dilks and Schmidt (2018) find that the status within the organization can subsequently become a liability when the perpetrator's job position (i.e. status) is instrumental in committing the deviant act. Finally, while prior literature has not examined the impact of the victim organization type on punishment severity, Benson and Madensen (2007) explain that varying situations provide varying 
opportunities for crime and that perpetrators of organizational crime have more access than traditional criminals. Therefore, we hypothesize that there are main effects of fraud severity, the perpetrator's status, and the organization type on the severity of fraud outcomes. Hypothesis 1

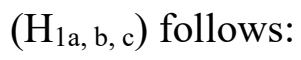

H1a: Fraud perpetrators face outcomes equal to the severity of their fraud act.

H1b: Fraud perpetrators with higher status face less severe outcomes than perpetrators with lower status.

Hic: Compared to publicly traded organizations, fraud perpetrators in privately held, governmental and not-for-profit organizations face less severe outcomes.

\subsubsection{Fraud severity and the perpetrator's status impact on outcome severity}

We rely on the consequentialist view of retributive theory to examine the relationship between occupational fraud seriousness and outcome severity, and whether the relationship differs based on the perpetrator's status or the victim organization type. Based on the consequentialist view of retributive theory and its application in occupational frauds, we argue that the severity of punishment is determined not only by the severity of fraud but also by the perpetrator's status or the victim organization type (Eitle 2000; Dilks et al. 2015; Arnulf and Gottschalk 2013; van Prooijen and Lam 2007; Roberts and Lyons 2009). Crime attributes and perpetrator characteristics have separately been shown to have direct effects on punishment (Eitle 2000; Roberts and Lyons 2009); Holtfreter 2008b). We examine various status characteristics, including the position within the company to test these findings. 
The ACFE (2018) reports that 19 percent of the fraud cases in their survey were committed by owners/executives, 34 percent by managers, and 44 percent by employees. Further, it reports that the gender split of the perpetrators is 69 percent male and 31 percent female. Finally, although occupational fraudsters are more educated than street criminals, the ACFE report finds that 24 percent have a high-school or lower education. These status differences within occupational fraudsters yield the varying punishment severity for similar acts. However, as previously explained, the status becomes a liability (McGrimmon et al. 2018) when it is used to engage in wrongdoing. Therefore, we hypothesize the following:

H2: Both the fraud scheme and the perpetrators' status impact victim organization's decision in pursuing an outcome against fraud perpetrators.

\subsubsection{Fraud severity and the organization type impact on outcome severity}

The complexity of the crime environment has also been shown to have a positive relationship with punishment severity (Albonetti 1998). In occupational frauds, the victim organization is the crime environment. Kennedy (2014) explains that perpetrators gain a deep knowledge of the victim organization through their occupational duties. This knowledge enables the perpetrator to develop a cognitive map (Brantingham and Brantingham 1993) of when, where, and how to commit occupational fraud without being detected by internal controls, as well as increasing his or her ability to conceal the crime (Benson and Madensen 2007). Organizations employ internal controls in lieu of societal controls to reduce the situational opportunities available for crimes to occur (Holtfreter 2005; Benson and Madensen 2007; Fleming, Hermanson, Kranachar and Riley 2016); however, those internal controls vary by the type of the organization (Fleming et al 2016). 
The complexity of internal controls employed by an organization may be affected by the regulatory requirements for the organization. For example, Fleming et al. (2016) find that publicly traded companies employ stronger anti-fraud measures than their privately-held counterparts. This is likely because of the level of public scrutiny that these organizations face and their structural complexity. Where there is a "high public visibility, organizational decisions may be shaped by" (Holtfreter 2008b, p. 309) formal sanctions, as public companies may suffer from reputation damage if their control environment is not strong (Dugan and Gibbs 2009). Separately, more complex organizational structures may have more complex control systems to help identify the individuals responsible for certain activities. Dugan and Gibbs (2009) show that the separation of duties amongst many employees in corporations reduces the ability to identify those responsible for wrongdoing. They explain that "attention must be paid to the organizational structure to determine the viability of" (Dugan and Gibbs, 2009, p.118) crime controls. Each situation is different, causing the level of control to vary by the victim organization type and the punishment severity to vary correspondingly.

In addition to the organizational considerations of internal controls, deterrence theory explains that the punishments pursued against criminals are chosen based on cost-benefit analyses (Rae and Subramanian 2008; Townsley and Birks 2008). Harsher prevention and deterrence measures often incur higher costs in the short-term but may decrease costs in the long-term by sending a strong anti-fraud message. Organizations prefer lower cost alternatives for prevention and deterrence and will likely select occupational fraud outcomes that limit their overall costs (Beneish et al. 2017). Such costs may include preventative anti-fraud measures, such as the cost of physical and process controls (Townsley and Birks 2008); detective anti-fraud measures, such 
as the costs of anomaly identification (Becker 1968; Kim and Kogan 2014); or costs associated with employee turnover or damaged reputation (Desai, Hogan and Wilkins 2006a).

We focus on the costs and benefits of terminating or criminally prosecuting the employee who perpetrated the fraud. A victim organization that pursues the termination and/or criminal prosecution will incur greater short-term costs through attrition, legal fees, time spent by current employees, and a loss of good reputation, but the message sent may reduce future fraudulent behavior and the likelihood of legal actions by third parties. Therefore, organizations with more complex internal control systems, or those subject to regulatory oversight, such as governmental entities or publicly traded companies, may be more willing to incur higher short-term costs by sending strong signals through harsh punishment. Incurring high short-term costs may prevent much larger long-term costs (Karpoff et al. 2008b). At the same time, taking no action against a fraud perpetrator will result in no cost in the short-term, but it may send a signal to other employees and stakeholders that the company condones or dismisses fraudulent behavior, which may result in long-term costs through the furtherance of fraudulent behavior by other employees or a reaction by stakeholders or regulatory agencies. In some cases, victim organizations may elect to retain an occupational fraudster to avoid the short-term costs of replacement (Beneish et al. 2017).

While there is debate as to whether the severity of a crime is more heavily influenced by the fraud characteristics or the crime environment (Benson and Moore 1992), we contend in hypothesis $3\left(\mathrm{H}_{3}\right)$ that it is the interaction of these attributes that has the greatest impact on our punishment measure, occupational fraud outcomes.

$\mathbf{H}_{3}$ : Both the fraud scheme and the type of organization impact victim organization's decision in pursuing an outcome against fraud perpetrators. 
Figure $4-2^{22}$ illustrates the association among fraud severity, the perpetrator's status, the organization type, and the fraud outcomes pursued by the victim organization.

[Insert Figure 4 - 2 here]

\subsection{MODELS AND SAMPLE}

\subsection{Sample}

The sample in this study is collected using the survey methodology by the ACFE. The ACFE is the world's largest anti-fraud organization, with more than 80,000 members, mainly CFEs. The ACFE has distributed a biennial survey to CFEs since 1993 (ACFE 2016, 1996). Participating CFEs are required to answer 80 questions on the single largest fraud case that they have investigated and that was closed two years prior to the survey date. In the 2013, 2015 and 2017 surveys, in addition to the single largest fraud case, the participating CFEs were provided the opportunity to report a second fraud case that they investigated. The data collected through this biennial survey are available to the academic research community through a data-grant application to the Institute for Fraud Prevention (IFP). We obtained the access to the ACFE dataset in January 2018 through a data-grant proposal presented in November 2017.

The ACFE upholds the anonymity of the companies and perpetrators involved in the fraud cases and takes steps to protect them. First, the name of the company is not requested in the survey. Second, to avoid any reverse identification of any fraud case from the information reported, the 60 largest fraud cases are deleted from the dataset. Third, to further promote anonymity, the fraud

\footnotetext{
${ }^{22}$ The list of variables used to operationalize each of the four constructs, their measurement, and the respective question number on the ACFE survey are summarized in Appendix A.
} 
amounts in the sample have been randomized at \pm 1 percent (Fleming et al. 2016). These measures protect the identity of the companies and at the same time make it impossible for researchers to link the ACFE dataset to other datasets (e.g., Audit Analytics, Compustat, etc.). Despite this limitation, the ACFE dataset is unique. First, the survey used to collect the data is backed by over 25 years of experience. Second, fraud cases reported in the dataset are global fraud cases. Finally, the dataset includes the fraud cases investigated from the beginning of 2002 (ACFE 2004) until October 2015 (ACFE 2016), a 14-year period.

\subsection{Empirical Model}

\subsubsection{Dependent variable: fraud outcome}

Occupational fraud outcomes include varying degrees of punishment from no action taken to the involuntary loss of employment, or criminal prosecution, or any combination of the two ${ }^{23}$. The two fraud outcomes that we examine in this study are termination and criminal prosecution. Termination (TERMINATION) is measured as a multiple response question in the ACFE survey. The multiple responses are "termination," "permitted or required the individual to resign," "probation/suspension," "restitution agreement," "no punishment," "perpetrator had resigned before fraud was discovered or action was taken," and "other." In our study, TERMINATION indicates whether the perpetrator continued to work for the victim organization after the fraud had been detected or not. Therefore, "termination ${ }^{24}$, " "permitted or required the individual to resign" and "perpetrator had resigned before fraud was discovered or action was taken" are coded as 1 to indicate that the perpetrators no longer works for the victim organization. However,

\footnotetext{
${ }^{23} \mathrm{ACFE}$ survey data included the civil litigation pursued against the perpetrators by the victim organization. Due to the limited data availability, this outcome is not examined in our study.

${ }^{24}$ Termination is defined in our study as no longer working for the organization.
} 
"probation/suspension," "restitution agreement," and "no punishment" are coded as 0 to indicate that the perpetrators still work for the victim organization. Observations that had only "others" as a selected response are not included in the final sample. Criminal prosecution (CRIMINAL) is measured as an indicator variable, where it equals 1 if the fraud case was referred to law enforcement and 0 otherwise.

Termination and criminal prosecution are non-mutually exclusive outcomes; therefore, our dependent variable FRAUDOUTCOME ${ }^{25}$ takes three different values: no punishment, termination only, and termination and criminal prosecution. Criminal prosecution without termination does not occur in practice, and as such, it is not considered a possible fraud outcome.

\subsubsection{Independent variables: fraud severity, perpetrator's status, and organization type}

Occupational frauds differ in duration, yield varying levels of loss to the victim organization, and are conducted by employees at all organizational levels. In deciding on the fraud outcome to pursue, victim organizations must consider the combination of these situations.

\section{Fraud Severity}

The National Survey of Crime Severity (NSCS) (Wolfgang, Figlio, Tracy and Singer 1985 ) is regarded as the preeminent ranking of 204 crime scenarios by severity in the United States. Participants in the NSCS selected severity scores for 25 of the 204 scenarios and consistently deemed property crimes severer when there were multiple victims or when the dollar loss was

${ }^{25}$ Observations are deleted as they had only "others" as a selected response, which does not indicate whether the perpetrator is terminated or not. Lastly, observations defined as contradictory responses are deleted because respondents selected conflicting responses for the termination question (Q74). For instance, "no punishment" and "termination" are both chosen as actions taken by the victim organization against the principal perpetrator. On the same note, 449 observations are deleted as they indicated that the principal perpetrator continued to work for the victim organization while being prosecuted criminally. Such a situation is illogical in practice. 
high. Thus, the severity of occupational frauds, a form of property crime, is measured by the number of victims and the resulting financial loss (Wolfgang et al. 1985). According to the ACFE (2018), median occupational fraud losses increase as the duration of the fraud increases, when the perpetrators engage in complicated fraud schemes such as financial statement fraud, and/or when there are multiple offenders. The duration of the fraud and the type of the enacted fraud scheme are related to the opportunities afforded in the victim organization's control environment, whereas the number of perpetrators is related to both the opportunities available in the victim organization's control environment and the perpetrator's characteristics. Other studies define crime severity as the duration of the offense, the crime type (Wheeler, et al. 1988; Weisburd et al. 1990), dollar loss (Tillman and Pontell 1992), and the number of perpetrators (Hagan and Parker 1985). Therefore, occupational frauds also may differ in seriousness, depending on whether they are committed by one individual or more than one individual, whether the crime might result in physical harm or cause harm to many victims, or whether the duration of or financial damage from the crime is above average for the fraud type. Therefore, multiple indicators are used in prior literature to measure fraud severity. Following are the indicators we use in this study.

Fraud Duration and/or Amount (FR_DURATION and FR_AMOUNT): Srinivasan (2005) examines the penalties for outside directors, particularly audit committee members, when their companies experience accounting restatements. The authors argue that the director departure is a function of restatement severity as measured by the duration of the restatement (i.e. the number of quarters for which the net income is restated), and by the magnitude (i.e. the cumulative amount of the restated net income scaled by total assets at the year-end before the restatement announcement). On the same note, Karpoff et al. (2008b) find that the managers' likelihood of a job loss increases with the cost that the financial misreporting causes to outside shareholders. We 
measure Fraud Duration as the number of months the scheme occurred before it was detected. Fraud amount is measured as the total sum of misappropriated assets or the amount of the caused loss.

Fraud Type (FR_TYPE): In the first National Survey of Crime Statistics (NSCS), Wolfgang et al. (1985) developed a crime severity scale, based on public opinions. They found that respondents' perception of crime seriousness was offense-specific. For example, they found that the asset misappropriation of occupational fraud schemes, such as stealing, overbilling, and embezzlement was more wrongful than harmful, whereas white-collar crimes committed by corporate offenders, such as selling defective products or causing injury through negligence were more harmful than wrongful. These results hold regardless of whether or not the respondent was a victim of crime (Rosenmerkel 2001). Therefore, the perceived seriousness of occupational frauds differs by type, and occupational fraud seriousness differs from the perceived seriousness of other white-collar crimes. We measure fraud type as either asset misappropriation (1) or other (0).

Collusion (COLLUSION): Perpetrators often co-offend in corruption and financial statement fraud schemes but may also collude in asset misappropriation schemes (Free and Murphy 2015). Weerman (2003) finds that collusion often occurs as a matter of social exchange. Co-offenders band together to accomplish more than a solo offender could on his or her own. Co-offending, or collusion, may also occur because the perpetrators have a perceived close tie (Free and Murphy 2015) to each other or to customers and suppliers (Bishop, Hermanson and Riley 2017). These ties facilitate group thinking and in-group behaviors (Gromet and Darley 2009), which can lead to cultural or "tone at the top" issues in management control (Cooper, Dacin and Palmer 2013). The trust formed between connected perpetrators further fuels social exchange in that each party believes the group will stick together or be punished together (Free and Murphy 2015). It is likely 
that this is the reason most collusive frauds are detected "by tip or complaint, internal audit, law enforcement, or by accident" (Bishop et al. (2017), p.18). Trust between co-offenders increases the severity of collusive frauds by motivating the participants to collaborate to conceal the crime, which reduces the likelihood of punishment (Paternoster 1987), but if detected, it may increase the level of punishment (Free and Murphy 2015). We define collusion as the number of perpetrators involved in the fraud.

\section{The Perpetrator's Status}

The perpetrator's status characteristics, such as age, economic status, race, gender (Ward et al. 2012; Benson and Gottschalk 2015), education, position in the victim organization, prior offense history, and behavioral indicators (Arnulf and Gottschalk 2013; Bishop et al. 2017; Hermanson et al. 2017; Holtfreter 2005; Piquero and Benson 2004) have been shown to have a direct effect on punishment. Rossi, Simpson and Miller (1985) find that the perpetrator's age and gender have both direct effects on the sentence length and indirect effects through the case complexity, while the perpetrator's education has an indirect influence on the sentence length, via case complexity. Similarly, Hollow (2014) finds that occupational fraudsters' positions within the company affect their motives. Finally, the ACFE (2018) reports that occupational fraud losses are positively related to the perpetrator's education, position in the organization, and tenure in the organization.

Age and/or Tenure (AGE and TENURE): Prior studies have examined age and/or tenure of board members (Srinivasan 2005), CEOs (Beneish et al. 2017), and CFOs and CEOs (Leone and Liu 2010), when comparing their retention rates in the financial misreporting and control firms. They

argue that age and/or tenure affect executive turnover (Collins, Masli, Reitenga and Sanchez 2008). Specifically, Collins et al. (2008) find that CFO age and tenure are significantly associated 
with the likelihood of CFO turnover. Desai et al. (2006b) compare the age and tenure of the CEO, chairman, and President of firms that restate earnings as compared to control firms, arguing that longer tenured executives are more difficult to replace. Univariate results show no significant difference between restating and control firms. However, in an additional analysis, the authors find that CEO age is negatively related to the likelihood of turnover, whereas the coefficient of CEO tenure is negatively related to the CEO turnover, but it is non-significant in the presence of CEO age in the model. Age is defined in our study as the age of the principal perpetrator at the time of the fraud.

Gender (GENDER): While many status characteristic traits are related to the possession and use of power and resources (e.g. tenure, education, position, age, prior convictions), others are nominal in nature, such as gender. Differences in nominal characteristics include categories with differentiated descriptive attributes that are not socially significant (Ridgeway 1991). Ridgeway (1991) explains that gender categories are distinct from other nominal traits as they are "two fairly equal groups" (p.382) that interact more frequently than other status groups and endure both the between-category as well as within-category bias. Therefore, while gender is deemed a status characteristic, it is not directly correlated with power and resources. We include it in our calculation of the perpetrator's status $(1=$ male, $0=$ female $)$ for theoretical and descriptive purposes only.

Position (POSITION): The position held by the perpetrator affects the fraud outcome as it impacts the status of the perpetrator in society. Piquero and Benson (2004) report that an analysis of the white-collar offenders in the 1980s revealed that white-collar crime was not an elite crime. On the contrary, most of the offenders were members of middle classes with moderate incomes and ordinary jobs, such as small-time entrepreneurs and mid-range office workers. In a more recent 
study, McGrimmon et al. (2018) examine the role of status in the sanctions that perpetrators suffered when committing white-collar crime. In the experimental design, the perpetrator's status is measured at two levels: "high status" (the perpetrator was a "lawyer") and "low status" (the perpetrator was a "billing clerk"). Overall, the results indicate that high status perpetrators face harsher sanctions than low status perpetrators. We measure the position as an employee, a manager, and an owner/executive.

Education (EDUCATION): Significant educational differences have been documented between repeated offenders and first-time offenders (Hermanson et al. (2017). Even though these differences have not been correlated with the outcomes, we expect education level to serve as a status characteristic and impact the fraud outcomes. We measure education as some college education or higher (1), or other (0).

Prior charges (PRIORCHARG): A considerable number of white-collar crime offenders are argued to be repeat offenders, identified by having had at least two prior official contacts with the criminal justice system (Piquero and Benson 2004). In addition, CEOs and CFOs with prior legal records are more likely to commit fraud (Davidson, Dey and Smith 2015). Furthermore, predators (repeat) and situational (first-time) fraudsters are found to be fundamentally different in several dimensions (Hermanson et al. 2017). We expect these differences to be reflected in the outcomes faced by the perpetrators. We use a dichotomous variable to show whether the perpetrator had prior charges (1) or not (0).

\section{The Organization Type}

Prior literature examines white-collar victim characteristics, including controls (Kimerling et al. 2002; Lyons 2006). Holtfreter (2005) considers the organization size, type (e.g. 
governmental, non-profit, publicly traded, or private), anti-fraud internal controls, and revenue as characteristics of victim organizations in occupational fraud cases. While neither study examines the punishments assigned for occupational frauds, these studies show that the variance between victim organization environments creates similarly varying opportunities and controls.

Organization Type (TYPE): The public versus private nature of the victim organization provides different opportunities and a lack of opportunities for occupational fraud to occur. Fleming et al. (2016) find that public organizations have stronger anti-fraud environments than private organizations. Also, public firms experience frauds that involve timing differences and involve a larger number of perpetrators. The authors argue that stronger anti-fraud controls force perpetrators to use less obvious fraud methods and involve more perpetrators to circumvent the controls. For instance, Holtfreter (2005) finds that publicly traded organizations experience more corruption than asset misappropriation, whereas non-profit entities experience more asset misappropriation cases than either financial statement fraud or corruption. We evaluate the victim organization type across four levels: publicly traded company, privately held company, nonprofit organization, and governmental agency.

\section{Control Variables}

Organization Size (SIZE): All prior studies, that examine the consequences to top management in misreporting organizations, control for the size of the organization. Some of these studies use natural $\log$ of sales as a proxy for the firm's size (Beneish et al. 2017; Leone and Liu 2010) while other studies use natural log of net sales (Agrawal and Cooper 2017).

Industry (INDUSTRY): The industry, where the victim organization operates, is widely controlled for in prior literature (Collins et al. 2008). Most studies match misreporting firms with control 
firms operating in the same industry (Leone and Liu 2010). We control for the following type of industries in this study, banking/financial service, manufacturing, public service, customer service and others.

Antifraud-measures (ANTIFRAUD): Holtfreter (2005) finds that anonymous tip lines and internal audits are more successful anti-fraud measures in corruption cases, as opposed to financial statement frauds and asset misappropriations. Similarly, Fleming et al. (2016) examine anti-fraud internal control differences between publicly traded and privately held companies, and find that financial statement frauds in publicly traded companies are complex and require conspicuous concealment measures. We tabulate the number of anti-fraud measures employed by victim organizations.

Location (LOCATION): The ACFE data consist of global fraud cases. In our study we control for organizations located in the United States of America (equals 1) as compared to locations outside the United States of America (equals 0).

\subsection{DESCRIPTIVE STATISTICS AND RESULTS}

\subsection{Descriptive Statistics}

Our final sample consists of 2,096 fraud cases. Table 4 - 1 reports the descriptive statistics for the full sample, whereas Table $4-2$ reports the descriptive statistics by outcome pursued against the principal fraud perpetrator. The principal perpetrator is neither terminated nor criminally prosecuted in 217 fraud cases in our data (10.4 percent), is terminated in fraud cases (25.5 percent), and is both terminated and criminally prosecuted in 1,344 fraud cases (64.1 percent). In most fraud cases, the principal perpetrator faces harsh punishment by losing their employment and facing criminal prosecution. Yet, in over 10 percent of the cases, the victim 
organization decides not to terminate the principal perpetrator and not to file any charges against him $/$ her $^{26}$. Approximately 88.7 percent of the fraud cases, reported in the ACFE dataset, involve asset misappropriation (AM) (11.3 percent are non-AM) that last for an average of 25.6 months and are committed by an average of 2.4 individuals.

The average age of the principal perpetrator is 41.5 years old, and there is a 65 percent 35 percent gender split between males and females, respectively. Principal perpetrators are well educated, with 69.8 percent having at least some college education (30.2 percent have high school or lower education). Only 11 percent of the principal perpetrators have had prior charges or convictions of a fraud-related offense. Most of the perpetrators in the data have an employee or managerial position, 42.9 percent and 39.6 percent, respectively. Perpetrators in the position of an executive, officer or owner comprise 17.5 percent of the cases in our data.

There are four types of organizations that are victims to a fraud scheme in our sample: publicly traded, privately held, governmental, and not-for-profit. Publicly traded and privately held firms represent the two largest groups at 30.8 percent and 42.5 percent, respectively. Governmental and not-for-profit organizations are the two smaller groups, 15.6 percent and 11.1 percent, respectively. Lastly, most of the victim organizations (59.2 percent) in our final sample are located in the United States., while the remaining 40.8 percent are located outside the United States of America.

We examine the sample descriptive statistics by outcomes pursued by victim organizations and find interesting differences among the three groups. On average, the fraud schemes where victim organizations pursue the harshest outcome, i.e. termination and criminal prosecution, cost

\footnotetext{
${ }^{26}$ In these cases, the principal perpetrator avoided being terminated by signing a restitution agreement, facing only temporary suspension/probation or facing no punishment at all.
} 
more ( $M=2.4$ natural log of fraud), last longer ( $M=27.7$ months $)$, and have the highest percentage of asset misappropriation schemes ( 92.7 percent), as compared to the other two outcome groups, no outcome and termination only. The median number of perpetrators in the harshest punishment group is one, whereas the median number of perpetrators in the other two groups is two. The average age of principal perpetrators who did not receive any punishment from the victim organization is higher $(M=45$ years old $)$ than perpetrators who were only terminated ( $M=41.2$ years old) or perpetrators who were terminated and criminally prosecuted $(\mathrm{M}=41$ years old $)$. Also, when comparing the percentage distribution within the groups, the no punishment group has the highest percentage of longer tenured, more educated, and higher ranked perpetrators among the three groups. The perpetrators who were terminated and criminally prosecuted are the youngest among the three groups ( $\mathrm{M}=41$ years old). In comparing the composition of this group, it has the highest percentages of low-tenured perpetrators, females, lower-ranked employees, and less educated perpetrators, but the highest percentage of perpetrators with prior fraud related charges. These univariate comparisons among the groups indicate that the higher status perpetrators tend not to receive any punishment from the victim organization, whereas the lower status perpetrators tend to receive the harshest punishment, by being terminated and criminally prosecuted.

Table 4 - 3 reports the Pearson and the Spearman correlation among the independent variables. The results show a statistically significant and positive Pearson correlation between the fraud severity indicators and the perpetrator's status indicators. The fraud duration has a positive and significant correlation with the perpetrator's age $(+0.34$, two tailed $p<0.000)$ and tenure $(+$ 0.36 , two tailed $\mathrm{p}<0.000$ ). However, the fraud amount has a positive and significant correlation with the age $(+0.29$, two tailed $\mathrm{p}<0.002)$ and position $(+0.33$, two tailed $\mathrm{p}<0.000)$ of the perpetrator. The perpetrator's education is significantly and negatively correlated with the fraud 
amount $(-0.18$, two tailed $\mathrm{p}<0.000)$; however, it is positively correlated with the fraud type (+ 0.12 , two tailed $\mathrm{p}<0.000)$. This correlation indicates that the more educated perpetrators commit asset misappropriation fraud, which results in a smaller fraud amount than financial statement fraud.

[Insert Table 4 - 1, Table 4 - 2 and Table 4 - 3 here]

\subsection{Multivariate Tests}

We examine three fraud outcomes that the victim organizations pursue against the principal perpetrators in occupation fraud cases: no outcome, termination, and termination and criminal prosecution. Based on the severity of the punishment, these three outcomes are ordered from the least severe (i.e. no punishment/outcome) to the severest (i.e. termination and criminal prosecution) while termination only stands in between. We use Multinomial Logit Regression ${ }^{27}$, where the termination outcome is used as a reference category, to compare the odds of the principal perpetrator facing one of the three outcomes. The Multinomial Logit Regression compares the odds of the principal perpetrator being terminated to not facing any outcome, and then it compares the odds of being terminated to being terminated and criminally prosecuted.

First, we test hypotheses $\mathrm{H1a}, \mathrm{H} 1 \mathrm{~b}$ and $\mathrm{H} 1 \mathrm{c}$, which argue that there is a main effect of fraud severity, the perpetrator's status, and the victim organization type on fraud outcomes, respectively, using Model 1 .

\section{Model 1:}

Fraud Outcome $=\alpha+\beta_{1} * F R \_D U R A T I O N+\beta_{2} * F R \_A M O U N T+\beta_{3} * F R \_T Y P E+\beta_{4} *$ COLLUSION +

$$
\beta_{5} * A G E+\beta_{6} * \text { TENURE }+\beta_{7} * \text { GENDER }+\beta_{8} * \text { POSITION }+\beta_{9} * \text { EDUCATION }+
$$

\footnotetext{
${ }^{27}$ We are not able to use Ordinal Logit Regression as the Proportional Odds assumption is not satisfied.
} 


$$
\begin{aligned}
& \beta_{10} * \text { PRIORCHARG }+\beta_{11} * \text { ORG_TYPE }+\beta_{12} * \text { ORG_SIZE }+\beta_{13} * I N D U S T R Y+ \\
& \beta_{14} * \text { ANTIFRAUD }+\beta_{15} * O R G_{-} L O C+\varepsilon
\end{aligned}
$$

Table $4-4$ reports the results from multinomial logistic regression, which we detail in Model 1. The first part of the table reports regression results when comparing no outcome to termination only, whereas the second part reports regression results when comparing termination only to termination and criminal prosecution. Consistent with our predictions, we find that the coefficients of the fraud severity indicators, except for collusion, are positive and significantly different from zero, when comparing the odds of the perpetrator being only terminated to being terminated and criminally prosecuted. More specifically, the effects of FR_DURATION $\left(\beta_{1}=+\right.$ 0.01 , two-tailed $\mathrm{p}<0.05)$, FR_AMOUNT $\left(\beta_{2}=+0.37\right.$, two-tailed $\left.\mathrm{p}<0.01\right)$, and FR_TYPE $\left(\beta_{3}=+1.16\right.$, two-tailed $\mathrm{p}<0.01)$ are all positive and significant. Thus, these results indicate that as fraud severity increases, the odds of being terminated and criminally prosecuted increase compared to the odds only being terminated. Therefore, there is a direct and positive association between the fraud severity and the severity of the punishment, consistent with our predictions in $\mathrm{H}_{1 \mathrm{a}}$.

When comparing no outcome to termination only, the coefficients of the fraud severity indicators are not significantly different from zero. The lack of significant association between the fraud severity indicators can be explained by two main factors. First, the sample of the no outcome firms is smaller than the other two groups. More specifically, it only encompasses 10.4 percent of the entire sample. Second, the question included in the ACFE surveys asks whether the perpetrator was terminated, or any other form of punishment was pursued, such as probation, suspension, or restitution agreement. Therefore, the no outcome group included cases where only temporary outcomes were pursued. 
When comparing the odds of the perpetrators receiving no outcome with being only terminated, we find that the coefficient of $A G E\left(\beta_{5}\right)$ is positive $(+0.03)$ and significantly different from zero (two-tailed $\mathrm{p}<0.01$ ). Also, when comparing the odds of being terminated to being terminated and criminally prosecuted, the coefficient of $A G E\left(\beta_{5}\right)$ is negative and significant $(-0.02$, two-tailed $\mathrm{p}<0.05)$, the coefficient of TENURE $\left(\beta_{6}\right)$ is positive and significant $(+0.28$, two-tailed $p<0.05)$, the coefficient of GENDER $\left(\beta_{7}\right)$ is negative and significant $(-0.59$, two-tailed $p<0.01)$, the coefficient of both levels of POSITION $\left(\beta_{8}\right)$, employee $(+0.60$, two-tailed $\mathrm{p}<0.01)$ and manager are positive and significant $(+0.42$, two-tailed $\mathrm{p}<0.05)$, the coefficient of EDUCATION $\left(\beta_{9}\right)$ is negative and significant $(-0.52$, two-tailed $\mathrm{p}$ $<0.01)$, and lastly, the coefficient of PRIORCHARG $\left(\beta_{10}\right)$ is positive and significant $(+0.95$, two-tailed $p$ $<0.01$ ). Consistent with our H1b hypothesis, these findings indicate that the perpetrator's status reduces the odds of being terminated and criminally prosecuted compared to only being terminated. Thus, older, male, better educated perpetrators, who are in an executive position and have worked for the victim organization for more than five years, are less likely to be terminated and criminally prosecuted than younger, female, less educated perpetrators, who are in an employee or managerial position and have worked for the victim organization for less than five years. Only prior fraud charges increase the odds of being terminated and criminally prosecuted as compared to only being terminated. Overall, we find that as the perpetrator's status increases, the odds of being terminated and criminally prosecuted decrease. Therefore, there is a direct and negative association between the perpetrator's status and the severity of the punishment as predicted in hypothesis $\mathrm{H}_{1 \mathrm{~b}}$.

Consistent with $\mathrm{H}_{1 \mathrm{c}}$, the coefficient of ORG_TYPE $\left(\beta_{11}\right)$ is positive and significantly different from zero. More specifically, when we compare the odds of the perpetrator receiving no outcome to the odds of being terminated, the coefficient of $O R G_{-} T Y P E\left(\beta_{11}\right)$ is positive and significantly different from zero for Governmental Organizations $(+1.19$; two-tailed $\mathrm{p}<0.01)$, Not-for-profit Organizations $(+0.86$; two-tailed $\mathrm{p}<0.05$ ), and Privately-held Organizations $(+0.84$; two-tailed $\mathrm{p}<0.01)$ when Publicly-held Organizations 
are used as the reference category. When comparing the odds of the perpetrator being terminated to being terminated and criminally prosecuted, the coefficient of $O R G_{-} T Y P E\left(\beta_{11}\right)$ is positive and significantly different from zero for Governmental Organizations $(+0.96$; two-tailed $p<0.01)$ and Not-for-profit Organizations $(+0.58$; two-tailed $\mathrm{p}<0.05)$. These findings indicate that compared to publicly traded organizations, governmental, not-for-profit, and privately held organizations are more likely to pursue no outcome against the principal perpetrator than to terminate him/her.

In other words, governmental, not-for-profit, and privately-held organizations choose extreme outcomes against the perpetrators. Governmental and not-for-profit organization are more likely to take no action than terminate the perpetrator and are more likely to terminate and criminally prosecute the perpetrator than to just terminate the perpetrator. Thus, governmental and not-for-profit organizations either decide to pursue no outcome or pursue the harshest outcome possible, as compared to just terminating the perpetrator.

[ Insert Table 4 - 4 here]

\subsubsection{Graph Distance Theory}

In hypothesis $\mathrm{H}_{2}$, we examine the effect of both the fraud severity and the perpetrator status. To test this hypothesis, we construct a composite variable for the perpetrator's status (STATUSCOMP) based on prior literature. Berger, Norman, Balkwell and Smith (1992) examine the impact of status attributes and other characteristics on the task performance expectations. The authors used a statistical approach that builds diagrams or graphs that connect the actor's characteristics to the expected task outcomes. Thus, there are various paths from the characteristics to the outcomes. These paths are characterized by the sign (positive or negative) and the length (various lengths based on how relevant the characteristic is to the task) dubbed graph theoretical 
distance. Figure 4 - 3 is a graph theoretical representation of one actor's salient diffused and specific status characteristics, adapted from Dilks et al. (2017). In our model, the diffused (D) status characteristics are age, tenure, gender, position, and education, whereas the specific (C) status characteristic is prior fraud related charges. Next, we determine the length of the paths for the diffused and specific variables, which in our case are paths of length three and four for both diffused and specific variables.

\section{[ Insert Figure 4 - 3 here]}

The perpetrator's ("P's") aggregate expectations values ${ }^{28}$ are reported in Table 4 - 5. Each path generates a value between +1 and -1 for the composite variable, depending on the sign and the length of the paths. To determine the specific variable combination for each path, we converted the perpetrator's position variable into a binary variable, where it equals to 1 if the perpetrator is an employee and zero otherwise. We also split age at 40 years old to obtain a binary variable. The 6 positive value and 0 negative value path include all cases where a perpetrator has the highest value on each of the variables, i.e. male ${ }^{29}$, older than 40 years old, with some college education, has worked for the victim organization for more than 5 years in a managerial or executive position, and has no prior charges. The 5 positive values and 1 negative value path includes any perpetrator who has at least one negative/low value in one of the indicators, and so on and so forth. The 0

\footnotetext{
28 The P's aggregate expectations values are estimated using a worksheet developed by Dr. David Melamed at University of Arizona. More information can be found at Melamed, D. (2011). Graded status characteristics and expectation states. In Advances in group processes (pp. 1-31). Emerald Group Publishing Limited.

${ }^{29}$ It is important to emphasize that even though gender is deemed a status characteristic, it is not directly correlated with power and resources. We include it in our calculation of the perpetrator's status for theoretical and descriptive purposes only.
} 
positive value and 6 negative values path includes females, younger than 40 years old, in an employee position, who have worked in the victim organization for less than five years, who do not have any college education, and have no prior charges.

[ Insert Table 4 - 5 here]

In our study, graph-theoretical procedure generates a Likert-scale score for the status of the perpetrators using the perpetrator's age, tenure, gender, position, education, and prior charges as status characteristics. Values closer to +1 indicate a high status, whereas values closer to -1 indicate a low status.

\subsection{Testing for Moderation}

Hypothesis $\mathrm{H}_{2}$ examines whether the main effect of fraud severity on fraud outcomes is moderated by the perpetrator's status. Baron and Kenny $(1986)^{30}$ is the seminal paper on defining moderator variables and providing the statistical method to test for moderation effects. The authors explain that moderator variables are third variables that partition a focal independent variable into subgroups to obtain the maximum effectiveness on a given dependent variable. In our study, the focal independent variable, crime severity, is partitioned initially into subgroups of perpetrators with different statuses, i.e. STATUSCOMP is the first moderator variable. Baron and Kenny argue that the partition of the focal independent variable by the moderator variable "affects the direction and/or strength of the relation between an independent or predictor variable and a dependent or criterion variable" (Baron and Kenny 1986, pg. 1174). In our study, prior literature has established a positive relation between the crime severity and punishment severity. However, status

\footnotetext{
${ }^{30}$ Baron and Kenny (1986) and Preacher and Hayes (2008) are two seminal papers that established the distinction between moderator and mediator variables and the statistical method to test for moderation or mediation effects. A mediator variable is defined as a mechanism/intervening variable through which the independent variable influences the dependent variable.
} 
characteristic theory argues that this relation does not hold when crime severity is subdivided into groups of perpetrators with different statuses. For instance, the association between crime severity and punishment severity is positive in the group of low status perpetrators; however, the relation is negative in the group of high-status perpetrators because high status perpetrators have higher education and income, which provides them with better tools to appeal the punishment that is pursued against them. The same argument is made when crime severity is subdivided into different groups of victim organizations. For instance, large publicly held organizations with several antifraud measures have the means to pursue any punishment against the perpetrators; however, small, privately held organizations with limited anti-fraud measures have limited means to pursue certain punishment against the perpetrators. The statistical method, suggested by Baron and Kenny, to test for moderation effects is the creation of an interaction term between the focal independent variable and the moderator variable. The moderation effect is supported when the regression coefficient of the interaction term is significant.

Next, we test hypothesis $2\left(\mathrm{H}_{2}\right)$, which examines whether the main effect of fraud severity on fraud outcomes is moderated by the perpetrator's status. In Model 2 we interact STATUSCOMP with fraud severity variables. We use this approach to save the degrees of freedom and improve the interpretation of the results.

\section{Model 2:}

Fraud Outcome $=\alpha+\beta_{1} * F R_{-} D U R A T I O N+\beta_{2} * F R_{-}$AMOUNT $+\beta_{3} * F R_{-}$TYPE $+\beta_{4} *$ COLLUSION +

$$
\begin{aligned}
& \beta_{5}{ }^{* S T A T U S C O M P}+\beta_{6} * \text { FR_DURATION*STATUSCOMP }+ \\
& \beta_{7} * F R \_ \text {AMOUNT } * S T A T U S C O M P+\beta_{8} * F R \_T Y P E * S T A T U S C O M P+ \\
& \beta_{9} * \text { COLLUSION } * \text { STATUSCOMP }+\beta_{10} * \text { ORG_TYPE }+\beta_{11} * \text { ORG_SIZE }+ \\
& \beta_{12} * \text { INDUSTRY }+\beta_{13} * \text { ANTIFRAUD }+\beta_{14} * O R G_{-} L O C+\varepsilon
\end{aligned}
$$


Table 4 - 6 reports the results from the multinomial logistic regression, which we detail in Model 2. The first part of the table reports regression results when comparing no outcome to termination only, whereas the second part reports regression results when comparing termination only to termination and criminal prosecution. In comparing the odds of receiving no punishment to being terminated, the coefficient of the interaction term FR_DURATION*STATUSCOMP $\left(\beta_{6}\right)$, FR_AMOUNT*STATUSCOMP $\left(\beta_{7}\right)$, FR_TYPE*STATUSCOMP $\left(\beta_{8}\right)$, and COLLUSION*STATUSCOMP $\left(\beta_{9}\right)$ is not statistically significant from zero. However, in comparing the odds of being terminated to being terminated and criminally prosecuted, we find that the status of the perpetrators interacts with the fraud duration, i.e. the coefficient of FR_DURATION*STATUSCOMP is positive $(+0.02)$ and significantly different from zero (two-tailed $\mathrm{p}<0.01$ ). Figure 4 - 4 shows the graphic representation of the interaction between the fraud duration and the perpetrator's status. In fraud cases with a short duration, low status perpetrators have a higher probability of being terminated and criminally prosecuted than high status perpetrators. As the fraud duration increases, perpetrators with different status have equal probability of being terminated and criminally prosecuted. In low severity cases, low status perpetrators receive a harsher punishment than high status perpetrators. As the fraud severity increases, perpetrators with different statuses receive the same punishment. Thus, victim organizations consider the perpetrator's status when pursuing an outcome in occupational fraud cases.

[Insert Table 4 - 6 and Figure 4 - 4 here]

Finally, we test hypothesis $3\left(\mathrm{H}_{3}\right)$, which examines whether the main effect of fraud severity on fraud outcomes is moderated by the type of the victim organization. In other words, we examine whether the positive association between fraud severity and fraud outcome is moderated by the type of the victim organization. In Model 3, we interact ORG_TYPE with fraud severity variables. 


\section{Model 3:}

Fraud Outcome $=\alpha+\beta_{1} * F R \_D U R A T I O N+\beta_{2}{ }^{*} F R \_$AMOUNT $+\beta_{3}{ }^{*} F R_{-}$TYPE $+\beta_{4}{ }^{*}$ COLLUSION +

$$
\begin{aligned}
& \beta_{5} * A G E+\beta_{6} * \text { TENURE }+\beta_{7} * \text { GENDER }+\beta_{8} * \text { POSITION }+\beta_{9} * \text { EDUCATION }+ \\
& \beta_{10} * \text { PRIORCHARG }+\beta_{11} * \text { ORG_TYPE }+\beta_{12} * \text { ORG_SIZE }+\beta_{13} * I N D U S T R Y+ \\
& \beta_{14} * \text { ANTIFRAUD }+\beta_{15} * \text { ORG_LOC }+\beta_{16} * \text { ORG_TYPE*FR_DURATION }+ \\
& \beta_{17} * \text { ORG_TYPE*FR_AMOUNT }+ \\
& \beta_{19} * \text { ORG_TYPE*FR_TYPE }+\varepsilon
\end{aligned}
$$

Table 4 - 7 reports the results from our multinomial logistic regression, which we detail in Model 3. Consistent with our predictions, we find that the coefficients of the fraud severity indicators interact with the organization type. When comparing the odds of no outcome to termination, the coefficient of ORG_TYPE*FR_DURATION $\left(\beta_{16}\right)$ is positive and significantly different from zero. More specifically, the coefficient of Governmental*FR_DURATION is +0.06 (twotailed $\mathrm{p}<0.01$ ), the coefficient of Non-Profit*FR_DURATION is +0.06 (two-tailed $\mathrm{p}<0.01$ ), and the coefficient of Private*FR_DURATION is +0.04 (two-tailed $\mathrm{p}<0.01$ ), as compared to publicly traded organizations, the reference category.

When comparing the odds of termination to termination and criminal prosecution, the coefficient of ORG_TYPE*FR_DURATION $\left(\beta_{16}\right)$ is significant only for governmental organizations, specifically, the coefficient of Governmental*FR_DURATION is +0.02 (two-tailed $p<0.1$ ). Figure $4-5$ shows the graphic representation of the fraud duration and organization type interaction. As the fraud duration increases, not-for-profit organizations are more likely to pursue no outcome than to terminate the perpetrator, as compared to publicly traded companies. Thus, as the fraud severity increases, the not-forprofit organizations tend not to pursue any outcome against the principal perpetrator. Conversely, as fraud duration increases, governmental and privately held organizations are more likely to terminate the perpetrators than pursue no outcome and to terminate and prosecute than just terminate, as compared to publicly traded companies. Thus, as the fraud severity increases, governmental and privately held 
organizations are more likely to pursue a harsher outcome. As Figure 4 - 6 shows, there is a positive relationship between the fraud severity and punishment severity when the victim organization is either a governmental entity or a privately held company, as compared to publicly traded companies.

[Insert Figure 4 - 5 and Figure 4 - 6 here]

Further, the results in Table 4 - 7 indicate a significant interaction between the organization type and fraud amount, ORG_TYPE*FR_AMOUNT $\left(\beta_{17}\right)$. In comparing the odds of receiving no outcome and being terminated, the coefficient of governmental*FR_AMOUNT is negative $(-0.24)$ and significantly different from zero (two-tailed $\mathrm{p}<0.1$ ), whereas in comparing the odds of being terminated to being terminated and criminally prosecuted, the coefficient of not-for-profit*FR_AMOUNT is positive $(+0.46)$ and significantly different from zero (two-tailed $\mathrm{p}<0.01)$. Figure $4-7$ shows the interaction between the organization type (ORG_TYPE) and fraud amount (FR_AMOUNT). As the amount of the misappropriated assets (i.e. fraud severity) increases, the probability that a governmental organization does not pursue any outcome decreases, as compared to publicly traded organizations. In contrast, Figure 4 - 8 shows that not-for profit organizations are more likely than publicly traded organizations to terminate and criminally prosecute perpetrators as the number of misappropriated assets increases.

[Insert Figure 4 - 7 and Figure 4 - 8 here]

Lastly, the results in Table $4-7$ report a significant interaction between ORG_TYPE*COLLUSION $\left(\beta_{18}\right)$ and ORG_TYPE*FR_TYPE $\left(\beta_{19}\right)$ when comparing the probability of being terminated to being terminated and criminally prosecuted. The coefficient of governmental*COLLUSION is negative $(-0.12)$ and significantly different from zero (two-tailed $\mathrm{p}<0.1$ ), and the coefficient of governmental*FR_TYPE is negative (-1.13) and significantly different from zero (two-tailed $\mathrm{p}<0.1$ ). Figure 4 - 9 shows that as the number of perpetrators involved in the fraud increases, 
governmental organizations are less likely to terminate and criminally persecute the principal perpetrators as compared to publicly traded organizations. Figure 4 - 10 shoes that governmental organizations are less likely to terminate and criminally prosecute the principal perpetrator in fraud cases that involve assets misappropriation than in other fraud cases when compared to publicly traded organizations.

[Insert Figure 4 - 9, Figure 4 - 10 and Table 4 - 7 here]

\subsection{CONLUSION}

When high-profile fraud cases were detected in early 2000s, organizations, victim to these fraud schemes, rushed to replace their top executives. Some executives resigned voluntarily while others were terminated. There was also a group of organizations which did not pursue any outcome against their top executives. This evidence indicate that organizations, victimized by these frauds, choose whether and how to punish fraudsters. In this study, we examine whether the victim organization's decision to pursue an outcome against their executives is affected by the severity of fraud, by the perpetrator's status and by the type of the organization.

We find that as fraud severity increases, the severity of the outcome pursued against the principal perpetrator increases as well. However, victim organizations pursue less severe outcomes against high status perpetrators, as compared to low status perpetrators in fraud cases with a short duration. As the fraud duration increases, however, victim organizations pursue equally severe outcomes against all perpetrators. Lastly, governmental, not-for-profit, and privately held organizations are more likely to pursue no outcome against principal perpetrators as compared to publicly traded organizations. However, governmental and not-for-profit organizations are more likely to terminate and criminally prosecute the principal perpetrators as compared to just termination. Thus, governmental and not-for-profit organizations decide to pursue the two extreme outcomes against the fraudsters, i.e. no outcome at all or termination and criminal prosecution. 
The findings of this study shed light on the multitude of factors that affect the outcomes pursued against the occupational fraud perpetrators. We conclude that the fraud outcome is determined not only by the severity of the fraud act, but also by the status of the perpetrator who committed the fraud and the type of the victim organization.

Our study contributes to criminology and white-collar crime literature by being the first to consider the perpetrator's status characteristics and the victim organization type as moderators to the relationship between crime severity and punishment severity. It further adds to occupational fraud literature in accounting by providing a context to the descriptive data in the ACFE's Report to the Nations. Our study further offers anti-fraud professionals, such as forensic accounting and fraud examination professionals, an insight into the interactions between the fraud scheme attributes and victim and perpetrator characteristics. This information may aid them in the design of internal controls or when advising victim organization clients. As such, our study has both research and practical implications.

As with any archival study, there are several limitations to this study. First, civil litigation is not examined as a possible fraud outcome due to data availability. Anecdotally, civil litigation is less common than criminal prosecution; however, it is still pursued in a considerable number of occupational fraud cases. Second, certain observations are deleted as the responses of the CFEs were contradictory or incomplete. For instance, when asked about the actions taken against the principal perpetrator, both probation/suspension and termination are selected. We cannot determine whether this is by mistake or by choice when the perpetrator is initially suspended and then terminated. 


\section{References}

. U.S. Securities and Exchange Commission 2015. Agency Financial Report.

25 SEC Docket 21982.

ACFE. 1996. Report to the nations on Occupational Fraud and Abuse.

- 2004. Report to the Nations on Occupational Fraud.

- 2016. Report to the Nations on on Occupational Fraud and Abuse.

- 2018. Report to the Nations on Occupational Fraud.

Agrawal, A., and T. Cooper. 2017. Corporate Governance Consequences of Accounting Scandals: Evidence from Top Management, CFO and Auditor Turnover. Quarterly Journal of Finance 07 (01).

Albonetti, C. A. 1998. Direct and inderect effects of case complexity, guilty pleas, and offender characteristics on sentencing for offenders convicted of a white-collar offense prior to sentencing guidelines. Journal of Quantitative Criminology 14 (4):353 - 378.

Armstrong, C. S., J. E. Core, and W. R. Guay. 2015. Why do CEOs hold so much equity? SSRN.

Armstrong, C. S., D. F. Larcker, G. Ormazabal, and D. J. Taylor. 2013. The relation between equity incentives and misreporting: The role of risk-taking incentives. Journal of Financial Economics 109 (2):327-350.

Arnulf, J. K., and P. Gottschalk. 2013. Heroic Leaders as White-Collar Criminals: An Empirical Study. Journal of Investigative Psychology and Offender Profiling 10 (1):96-113.

AU Section 508: Reports on Audited Financial Statements.

Baron, R. M., and D. A. Kenny. 1986. The moderator-mediator variable distinction in social psychological research: Conceptual, strategic, and statistical considerations. Journal of Personality and Social Psychology 51 (6):1173-1182.

Beasley, M. S., J. V. Carcello, and D. R. Hermanson. 1999. Fraudulent Financial Reporting: 1987 - 1997. Committee of Sponsoring Organizations of the Treadway Commission 1.

Beasley, M. S., J. V. Carcello, D. R. Hermanson, and T. L. Neal. 2010. Fraudulent Financial Reporting 1998 - 2007. Committee of Sponsoring Organizations of the Treadway Commission 2

- 2013. Analysis of Alleged Auditor Deficiencies in SEC Fraud Investigations; 19982010. Center for Audit Quality.

Becker, G. S. 1968. Crime and punishment; An economic approach. Journal of Political Economy.

Bedau, H. A. 1978. Retribution and the theory of punishment. The Journal of Philosophy 75 (11):601 - 620.

Beneish, M. D., C. D. Marshall, and J. Yang. 2017. Explaining CEO retention in misreporting firms. Journal of Financial Economics 123 (3):512-535.

Benson, M. L., and P. Gottschalk. 2015. Gender and white-collar crime in Norway: An empirical study of media reports. International Journal of Law, Crime and Justice 43 (4):535-552.

Benson, M. L., and E. Moore. 1992. Are white-collar and common offenders the same? An empirical and theoretical critique of a recently proposed general theory of crime. Journal of Research in Crime and Delinquency 29 (3):251-272.

Berger, J., B. P. Cohen, and M. Zelditch, Jr. 1971. Status characteristics and social interaction. Technical Report No. 42.

Berger, J., R. Z. Norman, J. W. Balkwell, and R. F. Smith. 1992. Status inconsistencty in task situations: A test of four status processing principles. American Sociological Review 57 (6):843-855. 
Bergstresser, D., and T. Philippon. 2006. CEO incentives and earnings management. Journal of Financial Economics 80 (3):511-529.

Bishop, C. C., D. R. Hermanson, and R. A. Riley. 2017. Collusive Fraud: Leader, Incident, and Organization Characteristics. Journal of Forensic Accounting Research.

Bockus, K., and F. Gigler. 1998. A theory of auditor resignation. Journal of Accounting Research 36 (2): 191 - 208.

Bonner, S. E., Z.-V. Palmrose, and S. M. Young. 1998a. Fraud type and Auditor litigation: An analysis of SEC Accounting and Auditing Enforcement Releases. The Accounting Review 73 (4):503 - 532.

. 1998b. Fraud type and Auditor litigation: An analysis of SEC Accounting and Auditing Enforcement Releases. . The Accounting Review 73 (4):503 - 532.

Brick, I. E., O. Palmon, and J. K. Wald. 2006. CEO compensation, director compensation, and firm performance: Evidence of cronyism? Journal of Corporate Finance 12 (3):403-423.

Burns, N., and S. Kedia. 2006. The impact of performance-based compensation on misreporting. Journal of Financial Economics 79 (1):35-67.

Bushman, R. M., R. J. Indjejikian, and A. Smith. 1996. CEO compensation: The role of individual performance evaluation. Journal of Accounting and Economics 21:161 - 193.

Cadman, B., M. E. Carter, and S. Hillegeist. 2010. The incentives of compensation consultants and CEO pay. Journal of Accounting and Economics 49 (3):263-280.

Cahill, M. T. 2007. Retributive justice in the real world. Washington University Law Review 85 (4).

Carcello, J. V., C. Hollingsworth, and S. A. Mastrolia. 2011. The effect of PCAOB inspections on Big 4 audit quality. Research in Accounting Regulation 23 (2):85-96.

Carcello, J. V., and A. L. Nagy. 2004. Audit Firm Tenure and Fraudulent Financial Reporting. AUDITING: A Journal of Practice \& Theory 23 (2):55-69.

Carlsmith, K. M. 2008. On Justifying Punishment: The Discrepancy Between Words and Actions. Social Justice Research 21 (2):119-137.

Carlsmith, K. M., J. M. Darley, and P. H. RObinson. 2002. Why do we punish? Deterrence and just deserts as motives for punishment. Journal of Personality and Social Psychology 83 (2):284-299.

Ceresney, A. 2013. Financial Reporting and Accounting Fraud. Speech at American Law Institute Continuing Legal Education, Washington, D.C., September 19.

—. 2016a. Speech. Keynote Address at Directors Forum, January 25. . 2016b. SEC Enforcement Division's focus on Auditors and Auditing. Keynote Address at American Law Institute Conference on Accountants' Liability: Confronting Enforcement and Litigation Risks, September 22.

Cheng, Q., and D. B. Farber. 2008. Earnings restatement, chnges in CEO compenstion, and firm performance. The Accounting Review 83 (5):1217 - 1250.

Cheng, Q., and T. D. Warfield. 2005. Equity inventives and earnings management. The Accounting Review 80 (2):2005.

Coffee, J. C. J. 2004. Gatekeeper failure and reform: The challange of fashioning relevant reforms. Boston University Law Review 84:301 - 364.

Cohen, L., C. Malloy, and L. Pomorski. 2012. Decoding inside information. The Journal of Finance 67 (3).

Coleman, J. W. 1987. Toward an integraded theory of white-collar crime. American Journal of Sociology 93 (2):406-439. 
Coles, J. L., N. D. Daniel, and L. Naveen. 2013. Calculation of compensation incentives and firm-related wealth using ExecuComp; Data, Program and Explanation. SSRN.

Collins, D., A. Masli, A. L. Reitenga, and J. M. Sanchez. 2008. Earnings Restatements, the Sarbanes-Oxley Act, and the disciplining of CFOs. Journal of Accounting, Auditing and Finance:1 - 34.

Cooper, D. J., T. Dacin, and D. Palmer. 2013. Fraud in accounting, organizations and society: extending the boundaries of research. SSRN.

Cornell, R. M., R. C. Warne, and M. M. Eining. 2009. The Use of Remedial Tactics in Negligence Litigation. Contemporary Accounting Research 26 (3):767-787.

Davidson, R., A. Dey, and A. Smith. 2015. Executives' "off-the-job" behavior, corporate culture, and financial reporting risk. Journal of Financial Economics 117 (1):5-28.

Davidson, R. H. 2018. Executive equity compensation and financial statement fraud. SSRN.

Davis, J. S., and H. L. Pesch. 2013. Fraud dynamics and controls in organizations. Accounting, Organizations and Society 38 (6-7):469-483.

Dechow, P. M., W. Ge, C. R. Larson, and R. G. Sloan. 2011. Predicting Material Accounting Misstatements*. Contemporary Accounting Research 28 (1):17-82.

Dechow, P. M., R. G. Sloan, and A. P. Sweeney. 1996. Causes and consequences of earnings manipulation: An analysis of firms subject to enforcement actions by the SEC. Contemporary Accounting Research 13 (1):1 - 36.

DeFond, M., and J. Zhang. 2014. A review of archival auditing research. Journal of Accounting and Economics 58 (2-3):275-326.

DeFond, M. L., J. R. Francis, and N. J. Hallman. 2016. Awareness of SEC Enforcement and Auditor reporting decisions. SSRN.

DeFond, M. L., J. R. Francis, and X. Hu. 2011. The geography of SEC enforcement and auditor reporting for financially distressed clients. $S S R N$.

Denis, D. J., P. Hanouna, and A. Sarin. 2006. Is there a dark side to incentive compensation? Journal of Corporate Finance 12 (3):467-488.

Desai, H., C. E. Hogan, and M. S. Wilkins. 2006a. The Reputational Penalty for Aggressive Accounting; Earnings Restatements and Management Turnove. The Accounting Review $81(1): 83-112$.

- 2006b. The Reputational Penalty for Aggressive Accounting; Earnings Restatements and Management Turnover. The Accounting Review 81 (1):83 - 112.

Dilks, L. M., T. S. McGrimmon, and S. R. Thye. 2015. Status, emotional displays, and the relationally-based evaluation of criminals and their behavior. Soc Sci Res 50:246-263.

Dittmann, I., and E. Maug. 2007. Lower salaries and no options? On the optimal structure of executive pay. The Journal of Finance 62 (1):303 - 343.

Efendi, J., A. Srivastava, and E. P. Swanson. 2007. Why do corporate managers misstate financial statements? The role of option compensation and other factors. Journal of Financial Economics 85 (3):667-708.

Eitle, D. J. 2000. Regulatory Justice: A re-examination of the influence of class position on the punishment of white-collar crime. Justice Quarterly 17 (4).

Erickson, M., M. Hanlon, and E. L. Maydew. 2006. Is There a Link between Executive Equity Incentives and Accounting Fraud? Journal of Accounting Research 44 (1):113-143.

Eutsler, J., E. B. Nickell, and S. W. G. Robb. 2016. Fraud Risk Awareness and the Likelihood of Audit Enforcement Action. Accounting Horizons 30 (3):379-392. 
Feng, M., W. Ge, S. Luo, and T. Shevlin. 2011. Why do CFOs become involved in material accounting manipulations? Journal of Accounting and Economics 51 (1-2):21-36.

Fleming, A. S., D. R. Hermanson, M.-J. Kranacher, and R. A. Riley. 2016. Financial Reporting Fraud: Public and Private Companies. Journal of Forensic Accounting Research 1 (1):A27-A41.

Fondacaro, M. R., and M. J. O'Toole. 2015. American Punitiveness and Mass Incarceration: Psychological Perspectives on Retributive and Consequentialist Responses to Crime. New Criminal Law Review: An International and Interdisciplinary Journal 18 (4):477-509.

Fracassi, C., and G. Tate. 2012. External networking and internal firm governance. The Journal of Finance 67 (1):153 - 194.

Free, C., and P. R. Murphy. 2015. The Ties that Bind: The Decision to Co-Offend in Fraud. Contemporary Accounting Research 32 (1):18-54.

Frydman, C., and D. Jenter. 2010. CEO compensation. Annual Review of Financial Economics 2 (1):75-102.

Garrett, B. L. 2015. THE CORPORATE CRIMINAL AS SCAPEGOAT. Virginia Law Review $101(7): 1789$ - 1854.

Goergen, M., and L. Renneboog. 2011. Managerial compensation. Journal of Corporate Finance 17 (4):1068-1077.

Green, T. H. 1999. Lectures on the principles of political obligation.

Gromet, D. M., and J. M. Darley. 2009. Retributive and restorative justice: Importance of crime severity and shared identity in people's justice responses. Australian Journal of Psychology 61 (1):50-57.

Hagan, J., and P. Parker. 1985. White-collar crime and punishment: the class structure and legal sanctioning of securities violations. American Sociological Review 50 (3):302-316.

Hall, B. J., and J. B. Liebman. 1998. Are CEOs really paid like bureaucrats? The Quarterly Journal of Economics 113 (3):653-691.

Harris, J., and P. Bromiley. 2007. Incentives to Cheat: The Influence of Executive Compensation and Firm Performance on Financial Misrepresentation. Organization Science 18 (3):350367.

Hart, H. L. A. 1959. The presidential address: prolegomenon to the principles of punishment. Proceedings of the Aristotelian Society 60:1-26.

Hermanson, D. R., S. Justice, S. Ramamoorti, and R. A. Riley. 2017. Unique characteristics of predator frauds. Journal of Forensic Accounting Research.

Hollow, M. 2014. Money, morals and motives. Journal of Financial Crime 21 (2):174-190.

Holtfreter, K. 2005. Is occupational fraud "typical" white-collar crime? A comparison of individual and organizational characteristics. Journal of Criminal Justice 33 (4):353-365.

Holtfreter, K., N. L. Piquero, and A. R. Piquero. 2008. And justice for all? Investigators' perceptions of punishment for fraud perpetrators. Crime, Law and Social Change 49 (5):397-412.

Hwang, B.-H., and S. Kim. 2009. It pays to have friends. Journal of Financial Economics 93 (1):138-158.

Jensen, M. C. 2005. Agency costs of overvalued equity. Financial Management 34:5-19.

Jensen, M. C., and W. H. Meckling. 1976. Theory of the Firm: Managerial behavior, agency costs and ownership structure. Journal of Financial Economics 3:305 - 360.

Jiang, J., K. R. Petroni, and I. Yanyan Wang. 2010. CFOs and CEOs: Who have the most influence on earnings management? Journal of Financial Economics 96 (3):513-526. 
Johnstone, K. M., and J. C. Bedard. 2003. Risk management in client acceptance decisions. The Accounting Review 78 (4):1003 - 1025.

. 2004. Audit firm portofolio management decisions. Journal of Accounting Research 42 (4):659 - 690.

Kadous, K., and M. Mercer. 2012. Can Reporting Norms Create a Safe Harbor? Jury Verdicts against Auditors under Precise and Imprecise Accounting Standards. The Accounting Review 87 (2):565-587.

Kallunki, J., J.-P. Kallunki, H. Nilsson, and M. Puhakka. 2018. Do an insider's wealth and income matter in the decision to engage in insider trading? Journal of Financial Economics 130 (1):135-165.

Kaplan, S. E., and D. D. Williams. 2013. Do Going Concern Audit Reports Protect Auditors from Litigation? A Simultaneous Equations Approach. The Accounting Review 88 (1):199-232.

Karpoff, J. M., A. Koester, D. S. Lee, and G. S. Martin. 2017. Proxies and Databases in Financial Misconduct Research. The Accounting Review 92 (6):129-163.

Karpoff, J. M., D. S. Lee, and G. S. Martin. 2008a. The cost to firms of cooking the books. The Journal of Financial and Quantitative Analysis 43 (3):581 - 611.

Karpoff, J. M., D. Scott Lee, and G. S. Martin. 2008b. The consequences to managers for financial misrepresentation. Journal of Financial Economics 88 (2):193-215.

Kedia, S., U. Khan, and S. Rajgopal. 2017. The SEC's Enforcement Record against Auditors. $S S R N$.

Kedia, S., and T. Philippon. 2009. The Economics of Fraudulent Accounting. Review of Financial Studies 22 (6):2169-2199.

Kim, Y., and A. Kogan. 2014. Development of an Anomaly Detection Model for a Bank's Transitory Account System. Journal of Information Systems 28 (1):145-165.

Kimerling, R., A. Rellini, P. L. Judson, and L. A. Learman. 2002. Gender differences in victim and crime characteristics of sexual assaults. Journal of Interpersonal Violence 17 (5):526-532.

Leone, A. J., and M. Liu. 2010. Accounting Irregularities and Executive Turnover in FounderManaged Firms. The Accounting Review 85 (1):287 - 314.

Lyons, C. J. 2006. Stigma or sympathy? Attributions of fault to hate crime victims and offernders. Social Psychology Quarterly 69 (1):39-59.

Malmendier, U., and G. Tate. 2005. CEO overconfidence and corporate investment. The Journal of Finance 60 (6).

McGrimmon, T. S., L. M. Dilks, and M. Schmidt. 2018. White-collar crime and the reverse status liability hypothesis. Working Paper.

Murphy, K. J. 2013. Executive compensation: Where we are, and how we got there. Handbook of the Economics of Finance. 2:211 - 356.

Murphy, K. J., and T. Sandino. 2010. Executive pay and "independent" compensation consultants. Journal of Accounting and Economics 49 (3):247-262.

Paternoster, R. 1987. The deterrent effect of the perceived certainty and severity of punishment: A review of the evidence and issues. Academy of Criminal Justice Sciences 4 (2).

Peecher, M. E., I. Solomon, and K. T. Trotman. 2013. An accountability framework for financial statement auditors and related research questions. Accounting, Organizations and Society 38 (8):596-620. 
Piquero, N. L., and M. L. Benson. 2004. White-Collar Crime and Criminal Careers. Journal of Contemporary Criminal Justice 20 (2):148-165.

Preacher, K. J., and A. F. Hayes. 2008. Asymptotic and resampling strategies for assessing and comparing indirect effects in multiple mediator models. Behavior Research Methods 40 (3):879-891.

Reffett, A. B. 2010. Can identifying and Investingating fraud risks increase auditors' liability? The Accounting Review 85 (6):2145 - 2167.

Roberts, A., and C. J. Lyons. 2009. Victim-Offender Racial Dyads and Clearance of Lethal and Nonlethal Assault. Journal of Research in Crime and Delinquency 46 (3):301-326.

Rollins, T. P., and W. G. Bremser. 1997. The SEC's enforcement actions against auditors; an auditor repuation and institutional theory perspective. Critical Perspectives on Accounting 8:191 - 206.

Rossi, P. H., J. E. Simpson, and J. L. Miller. 1985. Beyond crime seriousness; Fitting the punishment to the crime. Journal of Quantitative Criminology 1 (1):59 - 90.

RTTN, A.-. 2016. Report to the Nations on Occupational Fraud and Abuse. Global Fraud Studies.

Sabbagh, C., and M. Schmitt. 2016. Handbook of social justice theory and research. Springer Ed.

SEC. 2013-207. SEC charges three auditors in continuing crackdown on violations or failures by gatekeepers. Press Release, September 30.

Shu, S. Z. 2000. Auditor resginations: clientele effects and legal liability. Journal of Accounting and Economics 29:173 - 205.

Skoczylis, J. 2008. T. H. Greeen on punishment. Journal of Undergraduate Research 1 (2).

Srinivasan, S. 2005. Consequences of Financial Reporting Failure for Outside Directors: Evidence from Accounting Restatements and Audit Committee Members. Journal of Accounting Research 43 (2):291-334.

Tillman, R., and H. N. Pontell. 1992. Is justice "collar-blind"?: Punishing medicaid provider fraud. Criminology 30 (4).

Townsley, M., and D. J. Birks. 2008. Building better crime simulations: systematic replication and the introduction of incremental complexity. Journal of Experimental Criminology 4 (3):309-333.

van Prooijen, J.-W., and J. Lam. 2007. Retributive justice and social categorizations: the perceived fairness of punishment depends on intergroup status. European Journal of Social Psychology 37 (6):1244-1255.

Von Hirsch, A. 1992. Proportionality in the philosophy of punishment. Crime and Justice 16:5598.

Ward, C., H. Flowe, and J. Humphries. 2012. The effects of masculinity and suspect gender on perceptions of guilt. Applied Cognitive Psychology 26:482-488.

Weber, J., M. Willennborg, and J. Zhang. 2008. Does Auditor Reputation Matter The Case of KPMG Germany and ComROAD AG. Journal of Accounting Research 46 (4):941 - 972.

Weerman, F. M. 2003. Co-offending as social exchange: Explaining characteritics of cooffending. The British Journal of Criminology 43 (2):398 - 416.

Weisburd, D., E. Waring, and S. Wheeler. 1990. Class, status and the punishment of white-collar criminals. Law and Social Inquiry 15 (2):223 - 243.

Wheeler, S., D. Weisburd, E. Waring, and N. Bode. 1988. White collar crimes and criminals. American Criminal Law Review 258:331 - 357.

White, M. J. 2013. Remarks at the Securities Enforcement Forum, October 9. 
- 2015. Maintaining high-quality, reliable financial reporting: A shared and weighty responsibility. Keynote address at AICPA National Conference, December 9.

Wolfgang, M. E., R. M. Figlio, P. E. Tracy, and S. I. Singer. 1985. The national survery of crime severity. The Center for Studies in Criminology and Criminal LawS.

Eitle, D. J. 2000. Regulatory justice: A re-examination of the influence of class position on the punishment of white-collar crime. Justice Quarterly, 17(4): 809-839. 


\section{Appendix A}

\begin{tabular}{|c|c|c|}
\hline Variable & Measurement & $\begin{array}{l}\text { ACFE survey } \\
\text { Question }\end{array}$ \\
\hline \multicolumn{3}{|c|}{ DV - Dependent variable } \\
\hline Termination & $\begin{array}{l}\text { Indicator variable, where it equals } 1 \text { if the perpetrator no longer } \\
\text { worked for the victim organization after fraud was detected, and } 0 \\
\text { otherwise. }\end{array}$ & Q74 \\
\hline $\begin{array}{l}\text { Criminal } \\
\text { Prosecution }\end{array}$ & $\begin{array}{l}\text { Indicator variable, where it equals } 1 \text { if the fraud case was referred } \\
\text { to law enforcement for criminal prosecution, and } 0 \text { otherwise }\end{array}$ & Q75 \\
\hline Fraud Outcome & $\begin{array}{l}\text { It equals } 0 \text { if no outcome was pursued, i.e. the perpetrator was not } \\
\text { terminated and was not criminally prosecuted, } 1 \text { if termination only } \\
\text { was pursued, } 2 \text { if termination and criminal prosecution was } \\
\text { pursued. }\end{array}$ & Q74/Q75 \\
\hline \multicolumn{3}{|l|}{ IV- Fraud Severity } \\
\hline $\begin{array}{l}\text { Fraud } \begin{array}{l}\text { Duration } \\
(\text { FR_DURATION) }\end{array}\end{array}$ & $\begin{array}{l}\text { The number of months that the scheme had been ongoing before it } \\
\text { was initially detected. }\end{array}$ & Q41 \\
\hline $\begin{array}{l}\text { Fraud Amount } \\
(\text { FR_AMOUNT) }\end{array}$ & $\begin{array}{l}\text { Natural logarithm of the total dollar value of the amount of assets } \\
\text { that was misappropriated, or the amount of loss caused. }\end{array}$ & Q2 \\
\hline $\begin{array}{ll}\text { Fraud } & \text { Type } \\
(\text { FR_TYPE) } & \end{array}$ & $\begin{array}{l}\text { Indicator variable equal to } 1 \text { if the fraud scheme involved asset } \\
\text { misappropriation, and } 0 \text { otherwise. }\end{array}$ & Q6 \\
\hline $\begin{array}{l}\text { Collusion } \\
(\text { COLLUSION) }\end{array}$ & The number of perpetrators involved in the fraud scheme. & Q59 \\
\hline \multicolumn{3}{|c|}{ IV- Perpetrator Status } \\
\hline $\begin{array}{l}\text { Age } \\
(\mathrm{AGE})\end{array}$ & $\begin{array}{l}\text { Age of the principal perpetrator in years at the time of the } \\
\text { occupational fraud. }\end{array}$ & Q60 \\
\hline $\begin{array}{l}\text { Tenure } \\
\text { (TENURE) }\end{array}$ & $\begin{array}{l}\text { Indicator variable equal } 1 \text { if the principal perpetrator had worked } \\
\text { for the victim organization less than five years at the time } \\
\text { occupational fraud occurred, and } 0 \text { if } s \text { /he had worked for more } \\
\text { than five years. }\end{array}$ & Q61 \\
\hline $\begin{array}{l}\text { Gender } \\
\text { (GENDER) }\end{array}$ & It equals 1 if perpetrator is a male and 0 if $\mathrm{s} / \mathrm{he}$ is a female. & Q65 \\
\hline
\end{tabular}




\begin{tabular}{|c|c|c|}
\hline Variable & Measurement & $\begin{array}{l}\text { ACFE survey } \\
\text { Question }\end{array}$ \\
\hline $\begin{array}{l}\text { Position } \\
\text { (POSITION) }\end{array}$ & $\begin{array}{l}\text { The perpetrator position is measured at three levels: employee, } \\
\text { manager (includes supervisor) and executive (includes owner and } \\
\text { officer). }\end{array}$ & Q62 \\
\hline $\begin{array}{l}\text { Education } \\
\text { (EDUCATION) }\end{array}$ & $\begin{array}{l}\text { Indicator variable equal to } 1 \text { if the principal perpetrator's education } \\
\text { equals some college education or more, and } 0 \text { otherwise, i.e. the } \\
\text { perpetrators received high school graduation or less. }\end{array}$ & Q66 \\
\hline $\begin{array}{l}\text { Prior Charges } \\
\text { (PRIORCHARG) }\end{array}$ & $\begin{array}{l}\text { Indicator variable, where it equals } 1 \text { if the perpetrators has received } \\
\text { prior fraud-related charges, and } 0 \text { otherwise. }\end{array}$ & Q69 \\
\hline \multicolumn{3}{|c|}{ IV- Victim Organization Type } \\
\hline $\begin{array}{l}\text { Organization Type } \\
\text { (ORG_TYPE) }\end{array}$ & $\begin{array}{l}\text { The type of organization is measured at four levels: governmental } \\
\text { agency, publicly traded company, privately held company and not- } \\
\text { for-profit organization. }\end{array}$ & Q45 \\
\hline \multicolumn{3}{|c|}{ CV - Control Variables } \\
\hline $\begin{array}{l}\text { Organization Size } \\
\text { (ORG_SIZE) }\end{array}$ & $\begin{array}{l}\text { Natural logarithm of the victim organization's approximate gross } \\
\text { annual revenue. }\end{array}$ & Q47 \\
\hline $\begin{array}{l}\text { Industry } \\
\text { (INDUSTRY) }\end{array}$ & $\begin{array}{l}\text { The following industries are examined: banking/financial services, } \\
\text { manufacturing, public services (includes government and public } \\
\text { administration, religious, charitable, social services), customer } \\
\text { service (includes transportation and warehousing) and others. }\end{array}$ & Q49 \\
\hline $\begin{array}{l}\text { Anti-fraud } \\
\text { measures } \\
\text { (ANTIFRAUD) }\end{array}$ & $\begin{array}{l}\text { Total number of antifraud measures that victim organizations had } \\
\text { in place at the time that occupational fraud occurred. }\end{array}$ & Q51 \\
\hline $\begin{array}{l}\text { Organization } \\
\text { Location } \\
\text { (ORG_LOC) }\end{array}$ & $\begin{array}{l}\text { Indicator variable, where it equals } 1 \text { if the victim organization is in } \\
\text { the U.S.A., and } 0 \text { otherwise. }\end{array}$ & Q50 \\
\hline
\end{tabular}


Figure 4 - 1: General Crime Theory developed in Criminology Literature

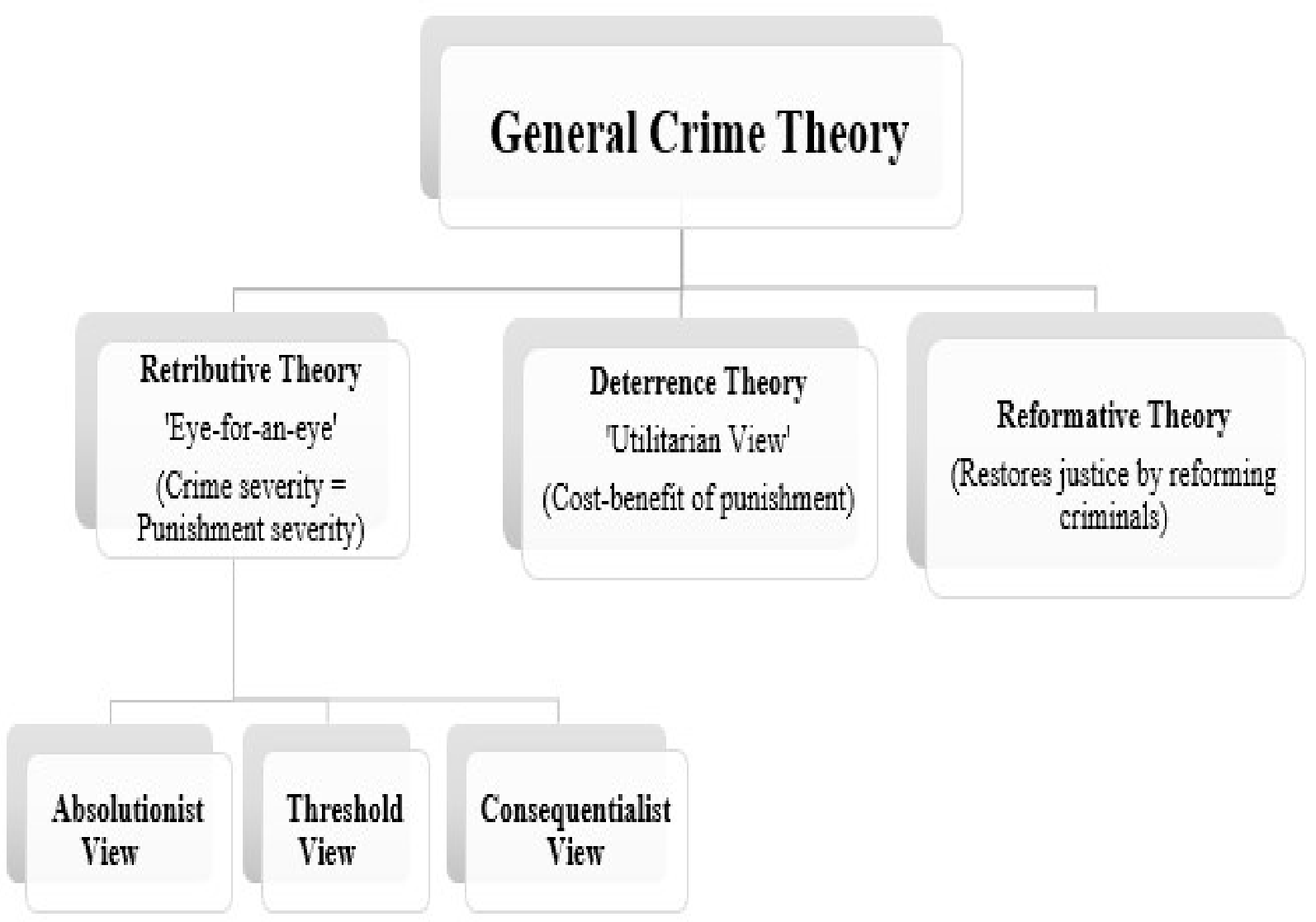


Figure 4 - 2: Theoretical Model of Fraud Outcome Determinants

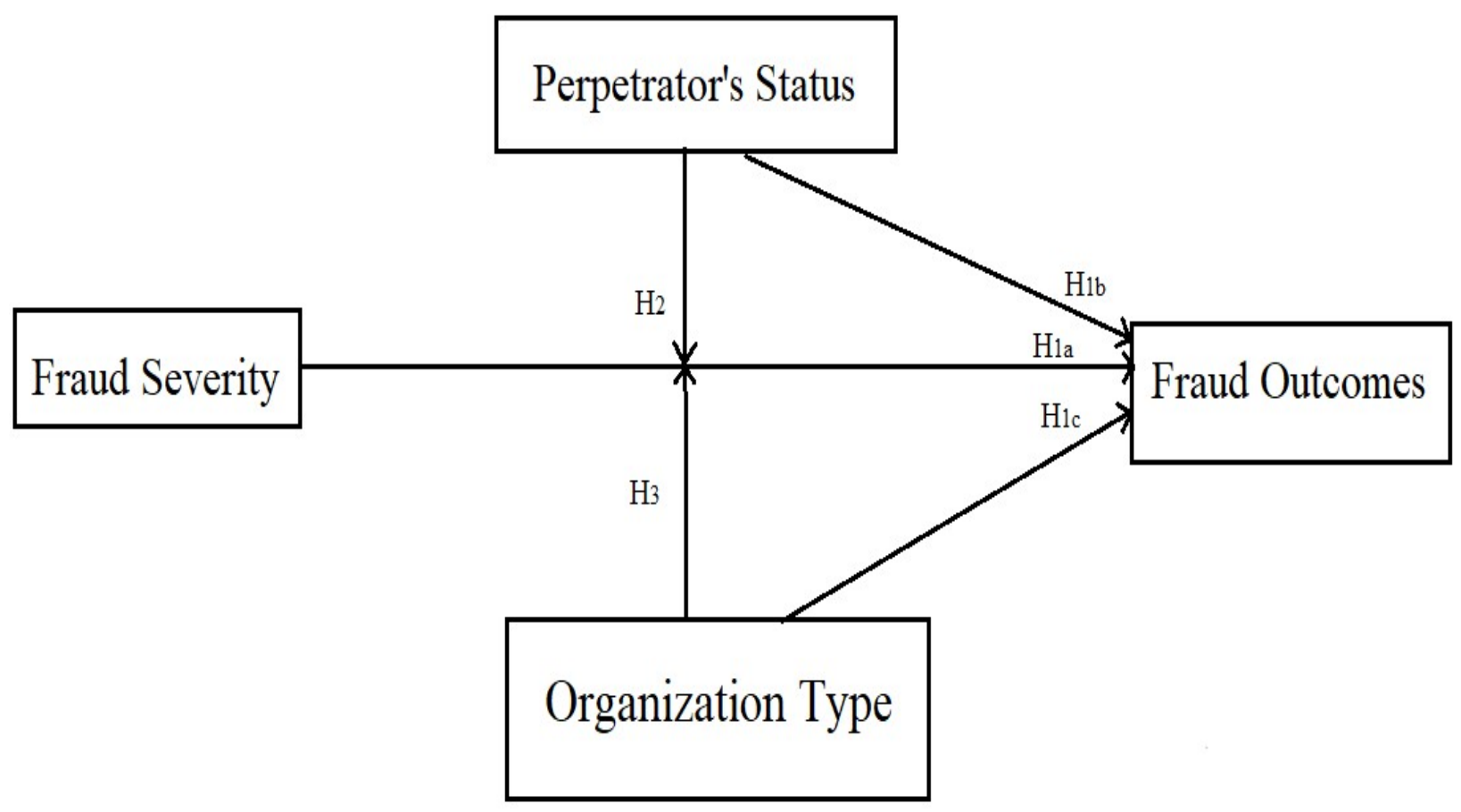


Figure 4 - 3: Graph Theoretic Representation of one Actor Salient

Diffuse (D) and Specific (C) Status Characteristic in an RET Setting.

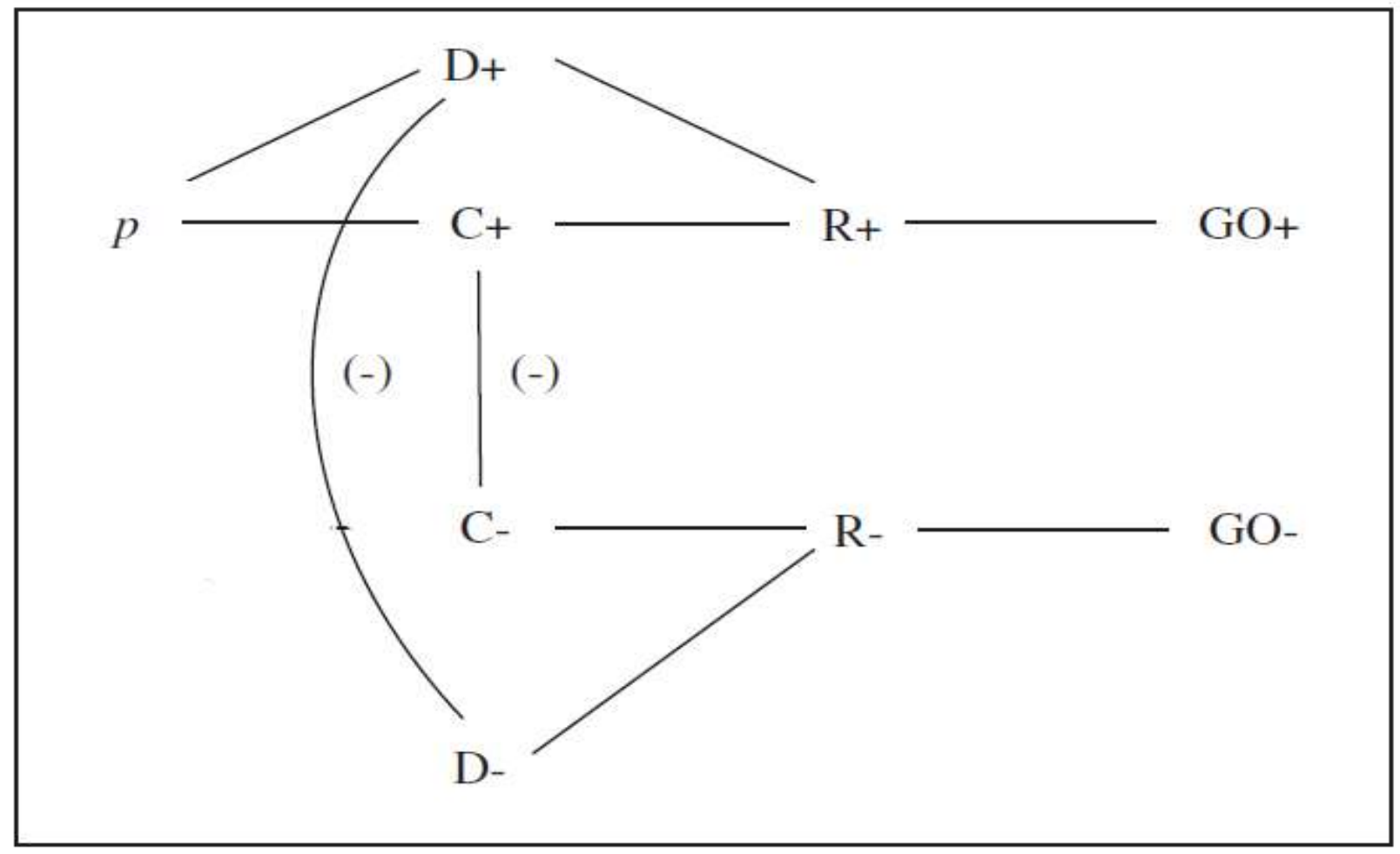

(Adapted from Dilks, L. M., McGrimmon, T. S., \& Thye, S. R. (2017). Assessing the Impact of Status Information Conveyance on the Distribution of Negative Rewards: A Preliminary Test and Model. In Advances in Group Processes (pp. 49-79). Emerald Publishing Limited.) 
Figure 4 - 4: Graphing Interaction - Pr (Termination and Criminal Prosecution)

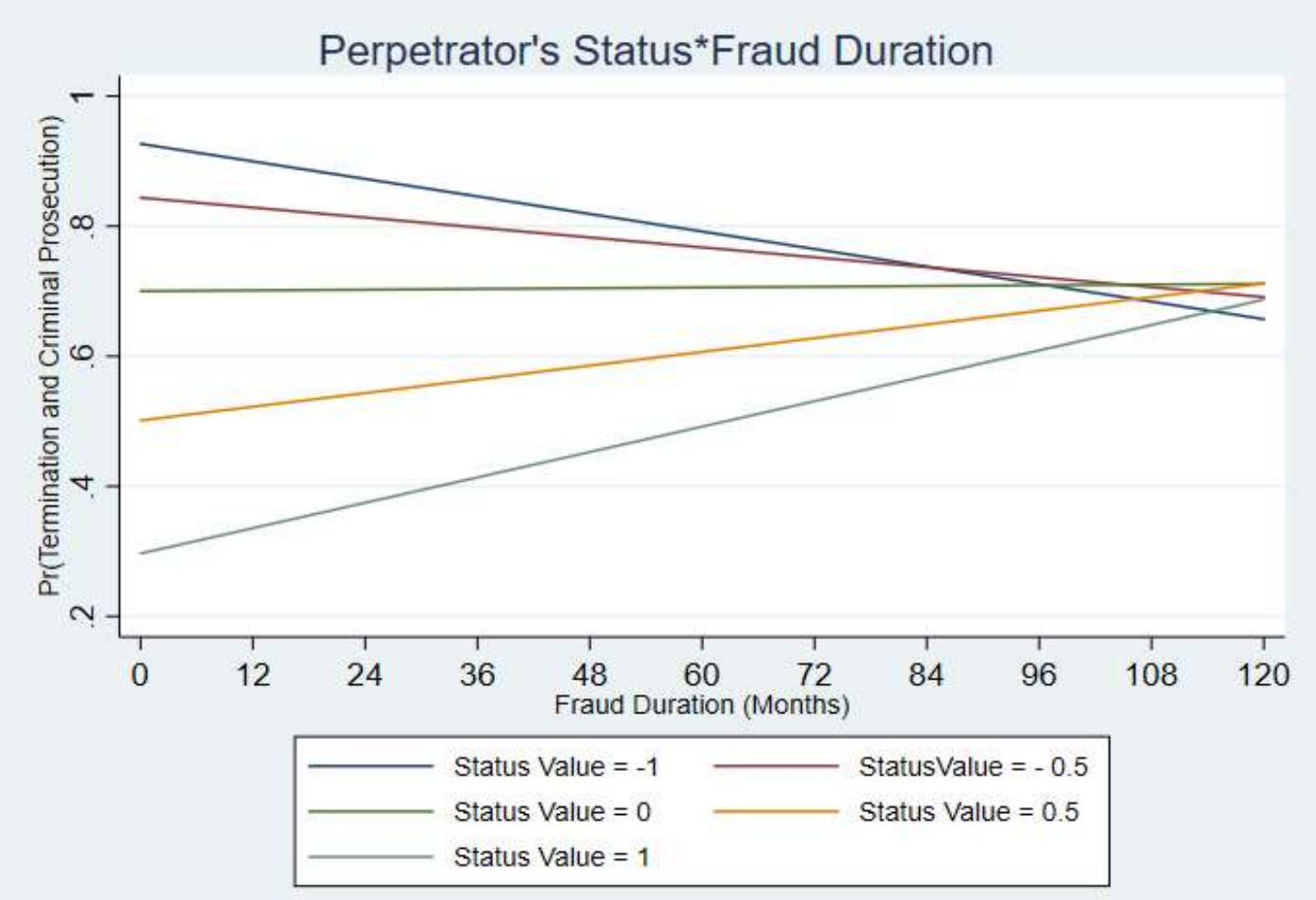


Figure 4 - 5: Graphing Interaction - $\operatorname{Pr}$ (No Outcome)

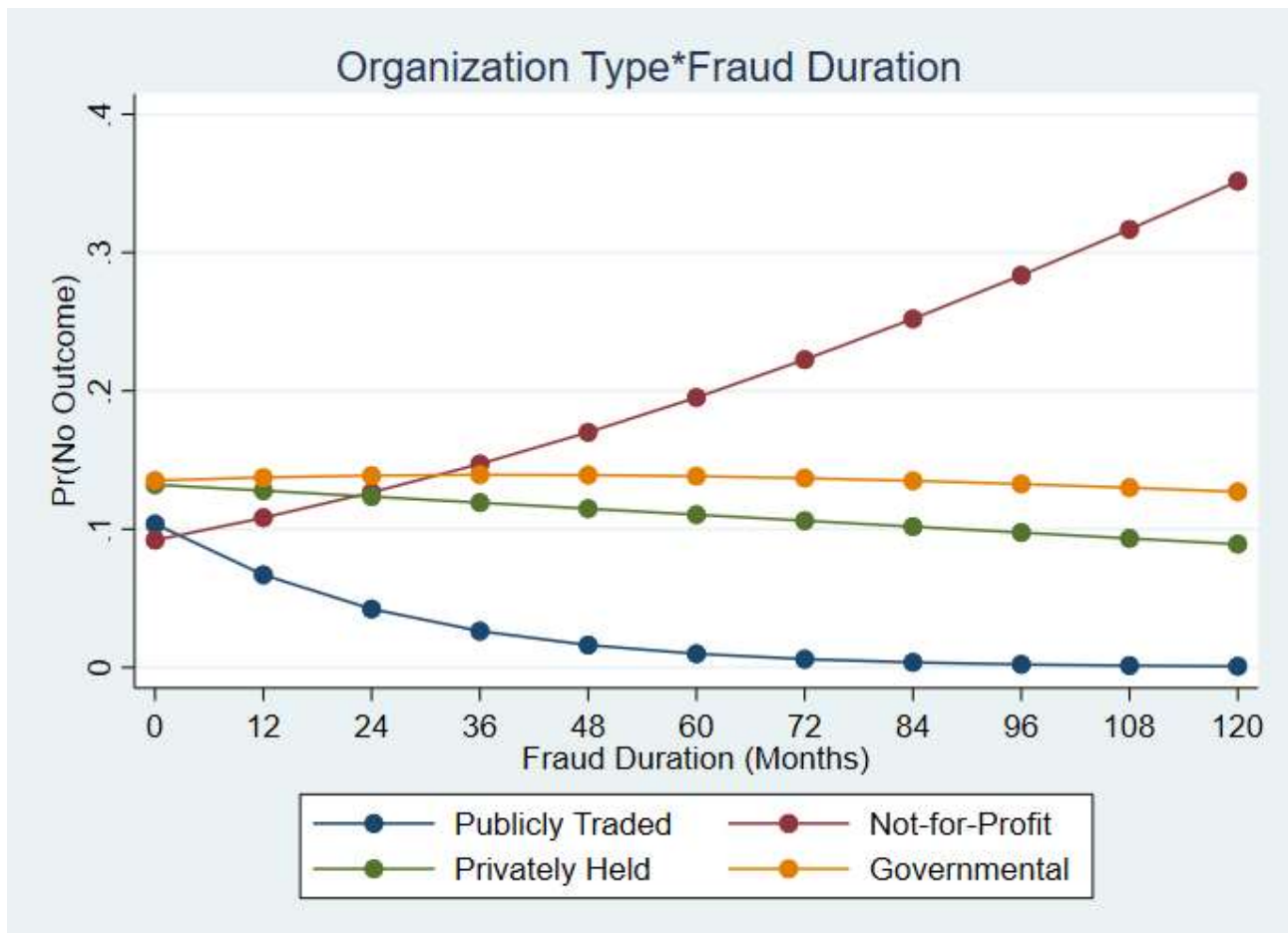


Figure 4 - 6: Graphing Interaction $-\operatorname{Pr}$ (Termination and Criminal Prosecution)

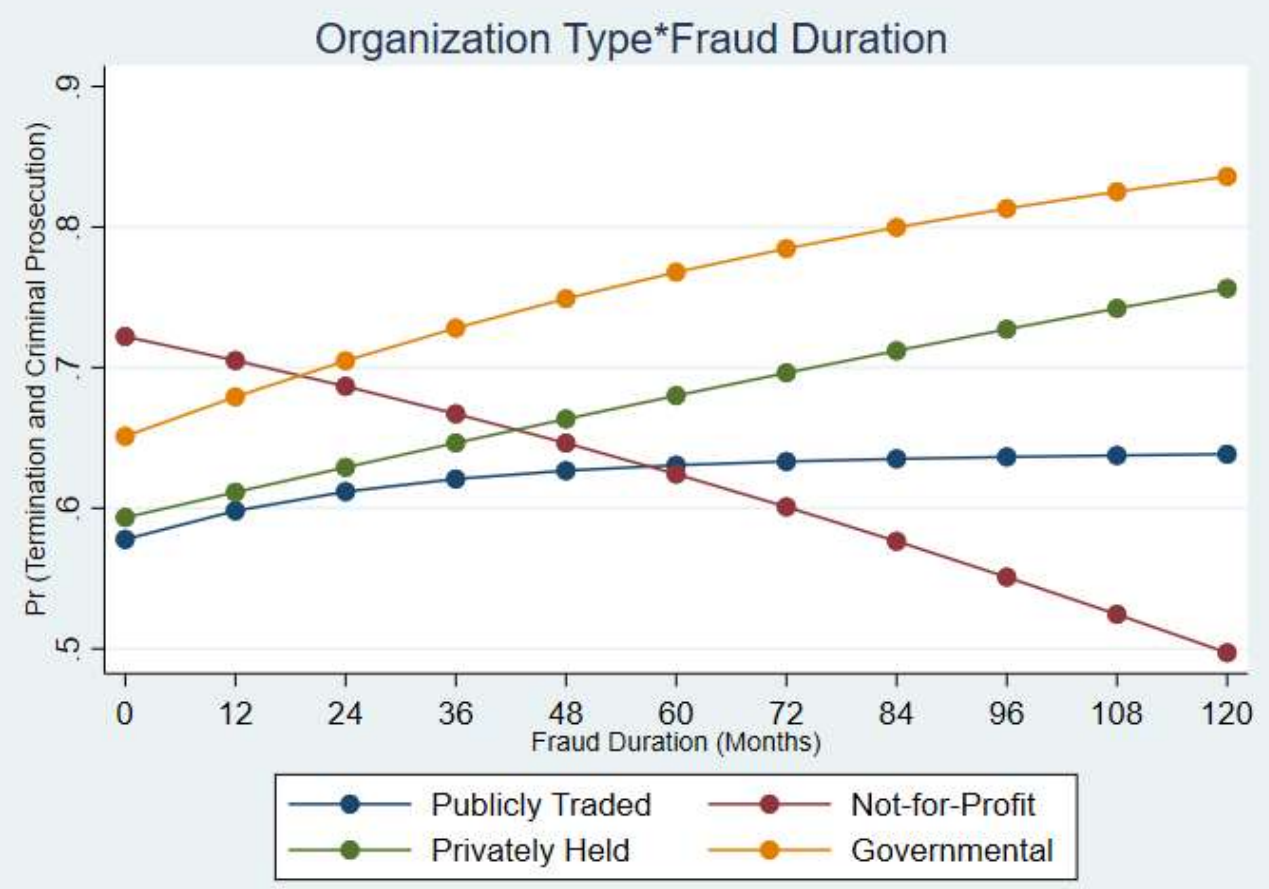


Figure 4 - 7: Graphing Interaction - Pr (No Outcome)

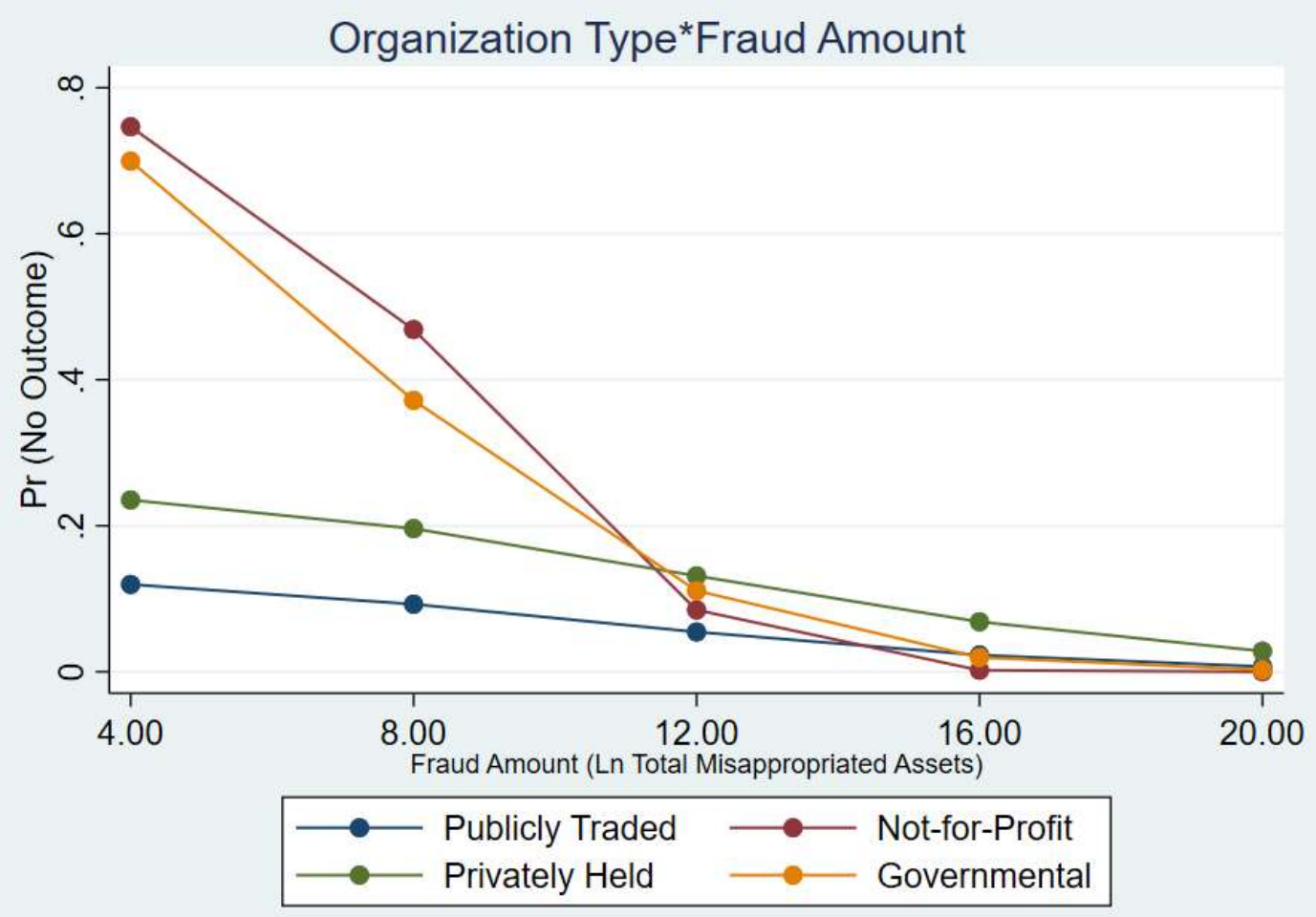


Figure 4 - 8: Graphing Interaction - $\operatorname{Pr}$ (Termination and Criminal Prosecution)

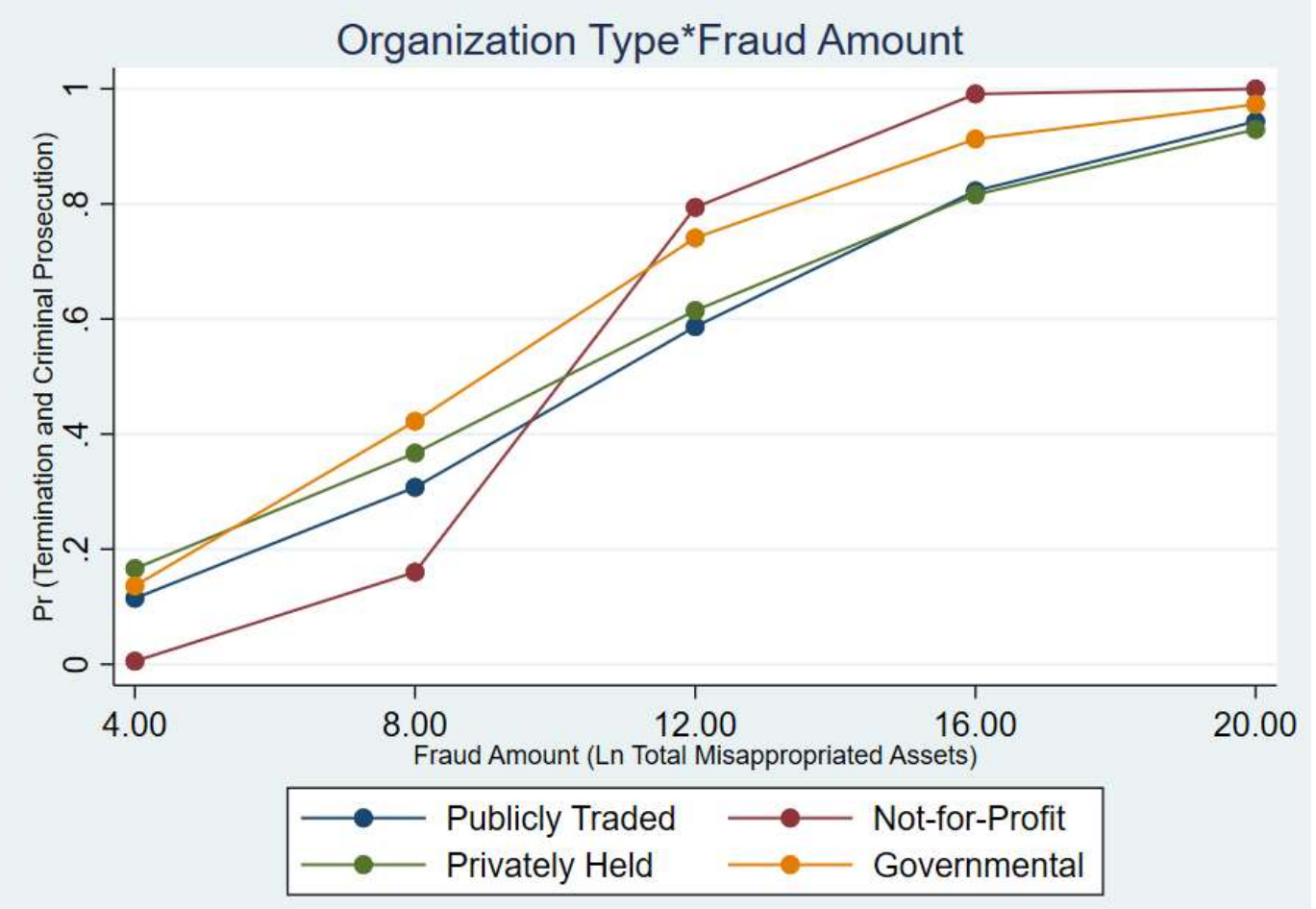


Figure 4 - 9: Graphing Interaction - $\operatorname{Pr}$ (Termination and Criminal Prosecution)

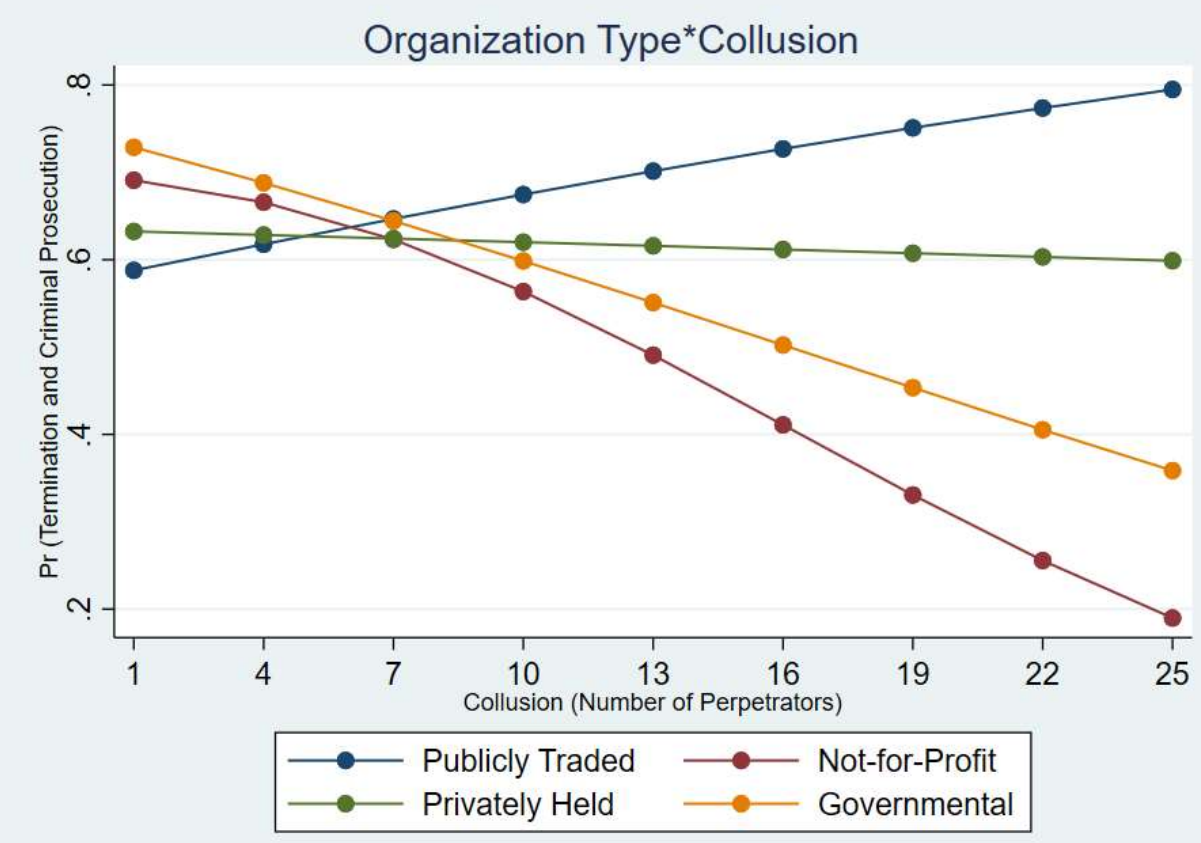


Figure 4 - 10: Graphing Interaction - Pr (Termination and Criminal Prosecution)

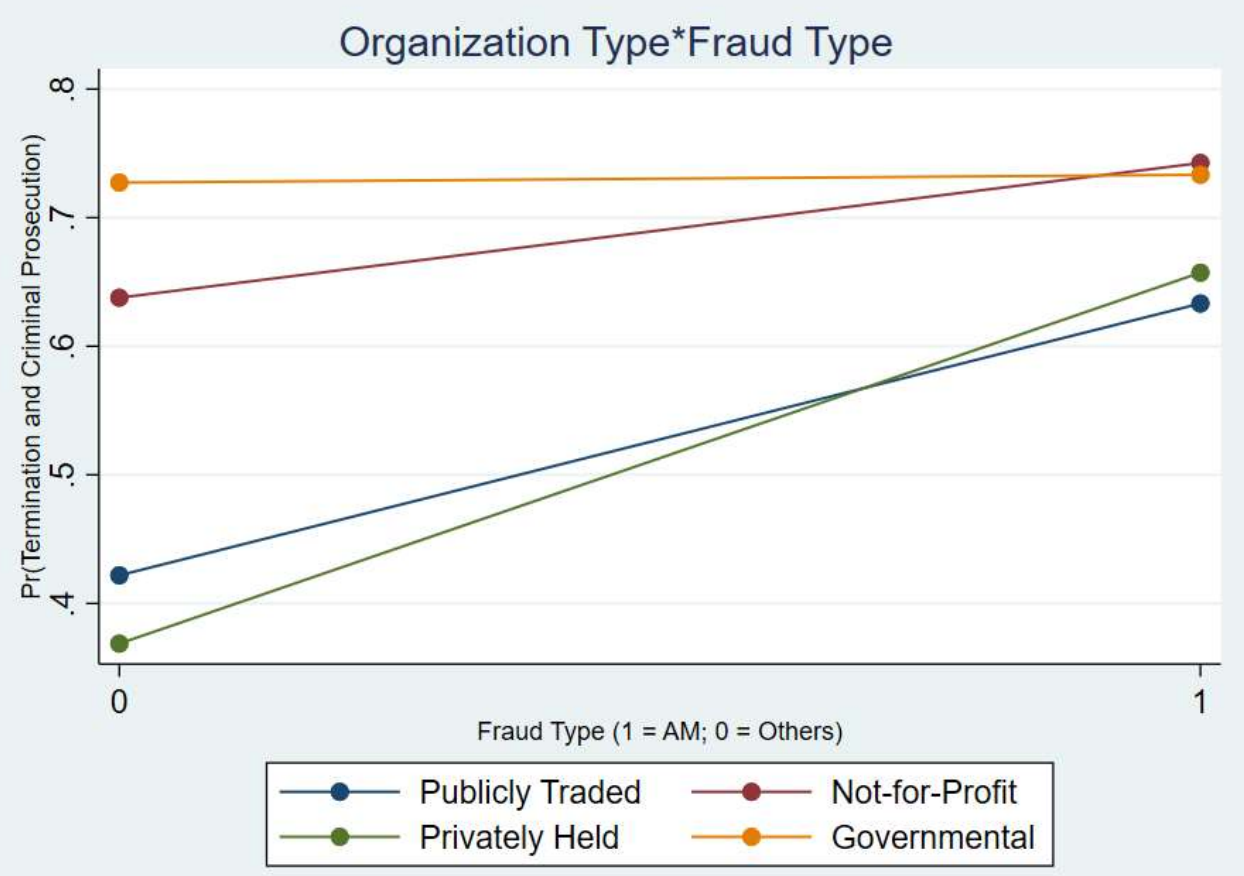


Table 4 - 1: Full Sample - Descriptive Statistics

$$
\mathbf{N}=\mathbf{2 , 0 9 6}
$$

Fraud severity

FR_DURATION

\begin{tabular}{llll}
\multicolumn{5}{c}{$\mathrm{N}=2,096$} \\
\hline Freq. Mean & Median Min. Max. Std. Dev.
\end{tabular}

FR_AMOUNT

\begin{tabular}{|c|c|c|c|c|c|}
\hline & 25.6 & 18.0 & 1.0 & 120.0 & 24. \\
\hline & 12.1 & 12.2 & 4.8 & 19.1 & 2.2 \\
\hline & 2.4 & 1.0 & 1.0 & 27.0 & 2.8 \\
\hline Obs. & $\%$ & & & & \\
\hline 1,860 & 88.7 & & & & \\
\hline 236 & 11.3 & & & & \\
\hline
\end{tabular}

\section{Perpetrator Status}

COLLUSION

FR_TYPE:

AGE

TENURE:

Less than 5 years

More than 5 years

$$
\begin{array}{r}
A M \\
\text { Non- } A M
\end{array}
$$

\begin{tabular}{cc} 
& 41.5 \\
\hline Obs. & \% \\
\hline 1,005 & 47.9 \\
1,091 & 52.1
\end{tabular}

GENDER:

$\begin{array}{rcc}\text { Male } & 1,355 & 64.6 \\ \text { Female } & 741 & 35.4\end{array}$

POSITION:

Employee

Manager

Executive

$899 \quad 42.9$

$830 \quad 39.6$

$367 \quad 17.5$

EDUCATION:

HS or less

$\begin{array}{ll}632 & 30.2\end{array}$

Some college or more

\begin{tabular}{|c|c|}
\hline Yes & 230 \\
\hline No & 1,866 \\
\hline
\end{tabular}

$1,464 \quad 69.8$

PRIORCHARG:

\section{Victim Organization Type}

ORG_TYPE:

Publicly traded

Privately held

Governmental

Not-for-profit

\begin{tabular}{cc}
\hline Obs. & \% \\
\hline 645 & 30.8 \\
891 & 42.5 \\
328 & 15.6 \\
232 & 11.1
\end{tabular}

\section{Control Variables}

ORG_SIZE

$\begin{array}{lllll}18.2 & 18.1 & 4.6 & 32.6 & 3.5\end{array}$


ANTIFRAUD

INDUSTRY:

Banking

Manufacturing

Public Service

Customer Service

Others

\begin{tabular}{cc} 
& 7.3 \\
\hline Obs. & \% \\
\hline 380 & 18.1 \\
305 & 14.6 \\
261 & 12.5 \\
598 & 28.5 \\
552 & 26.3
\end{tabular}

7.0

0.0

18.0

4.9

LOCATION:

$\begin{array}{rrr}\text { US firms } & 1,240 & 59.2 \\ \text { Non-USfirms } & 856 & 40.8\end{array}$

Variable Definitions:

FR_DURATION = number of months that the scheme had been ongoing before it was detected $F R \_A M O U N T=$ natural logarithm of the total dollar value of the number of misappropriated assets or the amount of the caused loss

FR_TYPE $=$ indicator variable equal to 1 if the fraud scheme involved asset misappropriation and 0 otherwise

COLLUSION $=$ number of perpetrators involved in the fraud scheme

$A G E=$ Age of the principal perpetrator in years at the time of the occupational fraud

$T E N U R E=$ Indicator variable equal 1 if the principal perpetrator had worked for the victim organization less than five years at the time occupational fraud occurred, and 0 if $\mathrm{s} / \mathrm{he}$ had worked for more than five years

$G E N D E R=$ It equals 1 if perpetrator is a male and 0 if $\mathrm{s} / \mathrm{he}$ is a female

$P O S I T I O N=$ The perpetrator position is measured at three levels: employee, manager (includes supervisor), and executive (includes owner and officer)

$E D U C A T I O N=$ Indicator variable equal to 1 if the principal perpetrator's education equals some college or even higher education, and 0 otherwise, i.e. if the perpetrator has high school or lower education

PRIORCHARG = Indicator variable, where it equals 1 if the perpetrator received prior fraudrelated charges and 0 otherwise

$O R G_{-} T Y P E=$ The type of the organization is measured at four levels: governmental agency, publicly traded company, privately held company, and not-for-profit organization.

$O R G \_S I Z E=$ Natural logarithm of the victim organization's approximate gross annual revenue $I N D U S T R Y=$ The following industries are examined: banking/financial services, manufacturing, public services (includes government and public administration, religious, charitable, social services), customer service (includes transportation and warehousing), and others.

$A N T I F R A U D=$ Total number of antifraud measures that victim organizations had in place at the time that occupational fraud occurred

$O R G_{-} L O C=$ Indicator variable, where it equals 1 if the victim organization is in the United States and 0 otherwise 
Table 4 - 2: Descriptive Statistics by Outcome Type

\begin{tabular}{|c|c|c|c|c|c|c|c|c|c|c|c|c|}
\hline & \multicolumn{4}{|c|}{$\begin{array}{l}\text { No Punishment } \\
\quad(n=217)\end{array}$} & \multicolumn{4}{|c|}{$\begin{array}{l}\text { Termination Only } \\
\quad(n=535)\end{array}$} & \multicolumn{4}{|c|}{$\begin{array}{l}\text { Termination and Criminal Prosecution } \\
\qquad(\mathrm{n}=1,344)\end{array}$} \\
\hline & Freq. & Mean & Median & $\begin{array}{l}\text { Std. } \\
\text { Dev. }\end{array}$ & Freq. & Mean & Median & $\begin{array}{l}\text { Std. } \\
\text { Dev. }\end{array}$ & Freq. & Mean & Median & $\begin{array}{l}\text { Std. } \\
\text { Dev. }\end{array}$ \\
\hline \multicolumn{13}{|l|}{ Fraud severity } \\
\hline FR_DURATION & & 24.5 & 16.0 & 25.8 & & 20.9 & 14.0 & 20.2 & & 27.7 & 20.0 & 25.4 \\
\hline FR_AMOUNT & & 11.4 & 11.2 & 2.5 & & 11.6 & 11.5 & 2.2 & & 12.4 & 12.4 & 2.1 \\
\hline COLLUSION & & 2.4 & 2.0 & 2.3 & & 2.4 & 2.0 & 2.6 & & 2.4 & 1.0 & 2.9 \\
\hline FR_TYPE: & Obs. & $\%$ & & & Obs. & $\%$ & & & Obs. & $\%$ & & \\
\hline$A M$ & 188 & 86.6 & & & 426 & 79.6 & & & 1,246 & 92.7 & & \\
\hline Non-AM & 29 & 13.4 & & & 109 & 20.4 & & & 98 & 7.3 & & \\
\hline \multicolumn{13}{|l|}{ Perpetrator Status } \\
\hline AGE & & 45.0 & 45.0 & 9.7 & & 41.2 & 40.0 & 8.9 & & 41.0 & 40.0 & 9.7 \\
\hline TENURE: & Obs. & $\%$ & & & Obs. & $\%$ & & & Obs. & $\%$ & & \\
\hline Less than 5 years & 81 & 37.3 & & & 249 & 46.5 & & & 675 & 50.2 & & \\
\hline More than 5 years & 136 & 62.7 & & & 286 & 53.5 & & & 669 & 49.8 & & \\
\hline \multicolumn{13}{|l|}{ GENDER: } \\
\hline Male & 164 & 75.6 & & & 414 & 77.4 & & & 777 & 57.8 & & \\
\hline Female & 53 & 24.4 & & & 121 & 22.6 & & & 567 & 42.2 & & \\
\hline \multicolumn{13}{|l|}{ POSITION: } \\
\hline Employee & 58 & 26.7 & & & 201 & 37.6 & & & 640 & 47.6 & & \\
\hline Manager & 94 & 43.3 & & & 234 & 43.7 & & & 502 & 37.4 & & \\
\hline Executive & 65 & 30.0 & & & 100 & 18.7 & & & 202 & 15.0 & & \\
\hline
\end{tabular}


EDUCATION:

$\begin{array}{rcccccc}\text { HS or less } & 47 & 21.7 & 117 & 21.9 & 468 & 34.8 \\ \begin{array}{r}\text { Some college or } \\ \text { more }\end{array} & 170 & 78.3 & 418 & 78.1 & 876 & 65.2 \\ \text { Yes } & 15 & 6.9 & & & & \\ \text { No } & 202 & 93.1 & 27 & 5.0 & 188 & 14.0 \\ \text { RIORCHARG: } & 508 & 95.0 & 1,156 & 86.0\end{array}$

Victim Organization Type

\begin{tabular}{ccc} 
ORG_TYPE: & Obs. & \% \\
\cline { 2 - 3 } Publicly traded & 35 & 16.1 \\
Privately held & 108 & 49.8 \\
Governmental & 45 & 20.7 \\
Not-for-profit & 29 & 13.4
\end{tabular}

\begin{tabular}{cc}
\hline Obs. & \% \\
\hline 219 & 40.9 \\
221 & 41.3 \\
51 & 9.5 \\
44 & 8.2
\end{tabular}

\begin{tabular}{cc}
\hline Obs. & \% \\
\hline 391 & 29.1 \\
562 & 41.8 \\
232 & 17.3 \\
159 & 11.8
\end{tabular}

\section{Control Variables}

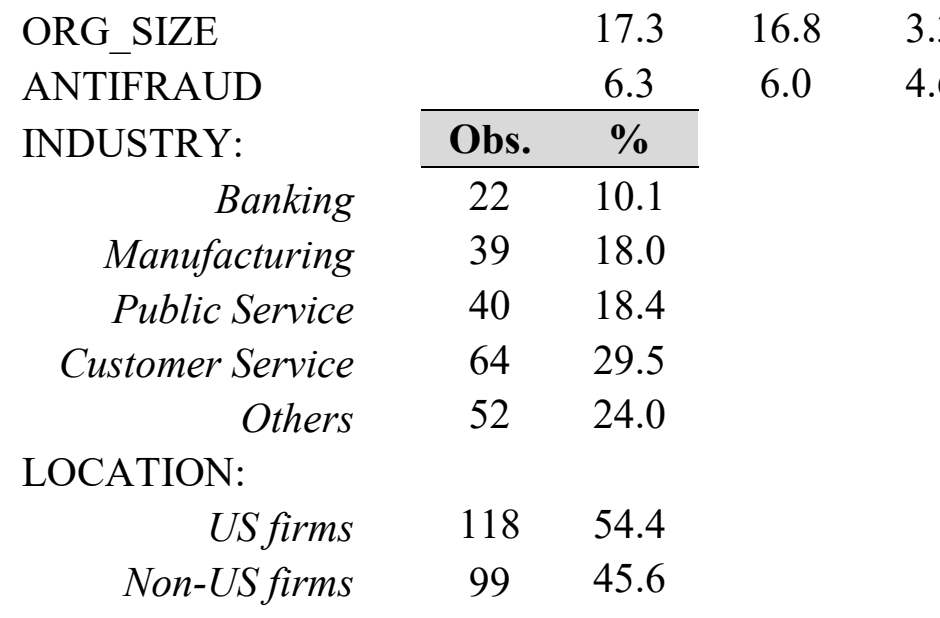

\begin{tabular}{cccc} 
& 18.5 & 18.6 & 3.5 \\
& 8.1 & 8.0 & 4.6 \\
\cline { 1 - 2 } Obs. & $\%$ & & \\
\cline { 1 - 2 } 80 & 15.0 & & \\
113 & 21.1 & & \\
44 & 8.2 & & \\
142 & 26.5 & & \\
156 & 29.2 & & \\
& & & \\
247 & 46.2 & \\
288 & 53.8 &
\end{tabular}

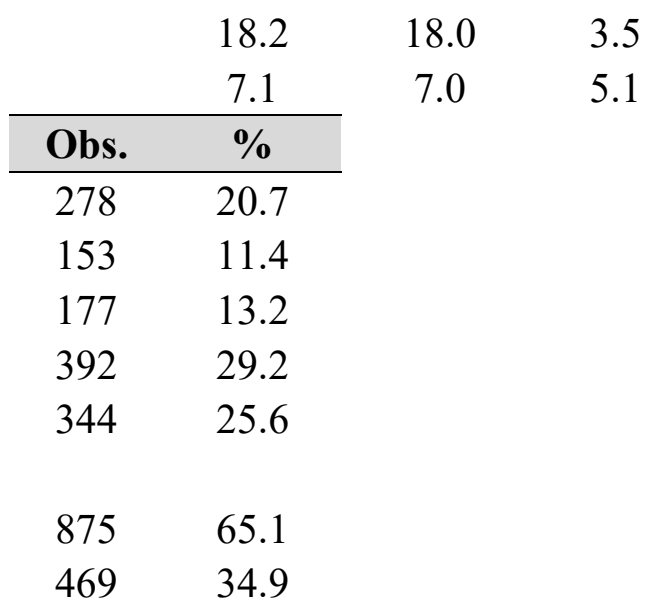

Variables are defined in Table $4-1$ and Appendix A. 
Table 4 - 3: Pearson (Upper)/ Spearman (Lower) Correlation Coefficients

\begin{tabular}{|c|c|c|c|c|c|c|c|c|c|c|c|c|c|c|}
\hline & \multicolumn{14}{|c|}{$(\mathrm{n}=2,096)$} \\
\hline & 1 & 2 & 3 & 4 & 5 & 6 & 7 & 8 & 9 & 10 & 11 & 12 & 13 & 14 \\
\hline 1 & & $0.36^{* *}$ & 0.02 & 0.00 & $0.34^{* *}$ & $0.36^{* *}$ & $-0.08^{* *}$ & $0.17^{* *}$ & -0.01 & 0.00 & $-0.11^{* *}$ & 0.04 & $0.05^{*}$ & $0.05^{*}$ \\
\hline 2 & $0.42^{* *}$ & & $-0.15^{* *}$ & $0.22^{* *}$ & $0.29^{* *}$ & $0.18^{* *}$ & $0.16^{* *}$ & $0.33^{* *}$ & $-0.18^{* *}$ & 0.00 & $0.06^{* *}$ & $0.08^{* *}$ & $-0.10^{* *}$ & $-0.10^{* *}$ \\
\hline 3 & 0.02 & $-0.13^{* *}$ & & $-0.09^{* *}$ & -0.02 & -0.03 & $-0.14^{* *}$ & $-0.09^{* *}$ & $0.12^{* *}$ & $0.06^{* *}$ & $-0.08^{* *}$ & 0.01 & $0.08^{* *}$ & 0.02 \\
\hline 4 & 0.02 & $0.30^{* *}$ & $-0.12^{* *}$ & & 0.04 & $0.05^{*}$ & $0.17^{* *}$ & $0.11^{* *}$ & $-0.07^{* *}$ & -0.02 & $0.11^{* *}$ & $-0.08^{* *}$ & $-0.07^{* *}$ & 0.02 \\
\hline 5 & $0.37^{* *}$ & $0.30^{* *}$ & -0.02 & $0.08^{* *}$ & & $0.39^{* *}$ & $0.08^{* *}$ & $0.40^{* *}$ & $-0.09^{* *}$ & -0.02 & $-0.11^{* *}$ & -0.01 & $0.05^{*}$ & $0.11^{* *}$ \\
\hline 6 & $0.37^{* *}$ & $0.18^{* *}$ & -0.03 & $0.07^{* *}$ & $0.39^{* *}$ & & 0.03 & $0.18^{* *}$ & -0.01 & $-0.12^{* *}$ & -0.02 & $-0.05^{*}$ & -0.01 & $0.17^{* *}$ \\
\hline 7 & $-0.08^{* *}$ & $0.16^{* *}$ & $-0.14^{* *}$ & $0.25^{* *}$ & $0.09^{* *}$ & 0.03 & & $0.28^{* *}$ & $-0.24^{* *}$ & $-0.09^{* *}$ & $0.12^{* *}$ & -0.01 & $-0.09^{* *}$ & $-0.07^{* *}$ \\
\hline 8 & $0.21^{* *}$ & $0.32^{* *}$ & $-0.09^{* *}$ & $0.21^{* *}$ & $0.41^{* *}$ & $0.18^{* *}$ & $0.28^{* *}$ & & $-0.29^{* *}$ & $-0.05^{*}$ & $-0.07^{* *}$ & $0.08^{* *}$ & 0.02 & -0.04 \\
\hline 9 & -0.03 & $-0.18^{* *}$ & $0.12^{* *}$ & $-0.11^{* *}$ & $-0.09^{* *}$ & -0.01 & $-0.24^{* *}$ & $-0.29^{* *}$ & & $0.11^{* *}$ & $-0.06^{* *}$ & 0.04 & -0.01 & 0.03 \\
\hline 10 & -0.01 & 0.00 & $0.06^{* *}$ & -0.04 & -0.02 & $-0.12^{* *}$ & $-0.09^{* *}$ & $-0.06^{* *}$ & $0.11^{* *}$ & & $-0.09^{* *}$ & $0.05^{*}$ & 0.04 & 0.01 \\
\hline 11 & $-0.11^{* *}$ & $0.05^{*}$ & $-0.08^{* *}$ & $0.12^{* *}$ & $-0.10^{* *}$ & -0.02 & $0.12^{* *}$ & $-0.06^{* *}$ & $-0.06^{* *}$ & $-0.09^{* *}$ & & $-0.57^{* *}$ & $-0.24^{* *}$ & $-0.28^{* *}$ \\
\hline 12 & 0.04 & $0.09^{* *}$ & 0.01 & $-0.07^{* *}$ & -0.02 & $-0.05^{*}$ & -0.01 & $0.07^{* *}$ & 0.04 & $0.05^{*}$ & $-0.57^{* *}$ & & $-0.30^{* *}$ & $-0.37^{* *}$ \\
\hline 13 & $0.05^{*}$ & $-0.10^{* *}$ & $0.08^{* *}$ & $-0.09^{* *}$ & $0.05^{*}$ & -0.01 & $-0.09^{* *}$ & 0.02 & -0.01 & 0.04 & $-0.24^{* *}$ & $-0.30^{* *}$ & & $-0.15^{* *}$ \\
\hline 14 & $0.05^{*}$ & $-0.10^{* *}$ & 0.02 & 0.02 & $0.11^{* *}$ & $0.11^{* *}$ & $-0.07^{* *}$ & -0.04 & 0.03 & 0.01 & $-0.29^{* *}$ & $-0.37^{* *}$ & $-0.15^{* *}$ & \\
\hline
\end{tabular}

\footnotetext{
**. Correlation is significant at the 0.01 level (2-tailed).
}

*. Correlation is significant at the 0.05 level (2-tailed). 


$$
\begin{aligned}
2 & =\text { FR_AMOUNT } \\
3 & =\text { FR_TYPE } \\
4 & =\text { COLLUSION } \\
5 & =\text { AGE } \\
6 & =\text { TENURE } \\
7 & =\text { GENDER } \\
8 & =\text { POSITION } \\
9 & =\text { EDUCATION } \\
10 & =\text { PRIORCHARG } \\
11 & =\text { PUBLICLY TRADED } \\
12 & =\text { PRIVATELY HELD } \\
13 & =\text { NOT-FOR-PROFIT } \\
14 & =\text { GOVERNMENTAL }
\end{aligned}
$$

Variables are defined in Table 4 - 1 and Appendix A 
Table 4 - 4: Multinomial Logit Regression for Outcome Pursued and Fraud Severity, Perpetrator Status and Victim Organization Type.

$$
(\mathrm{n}=2,096)
$$

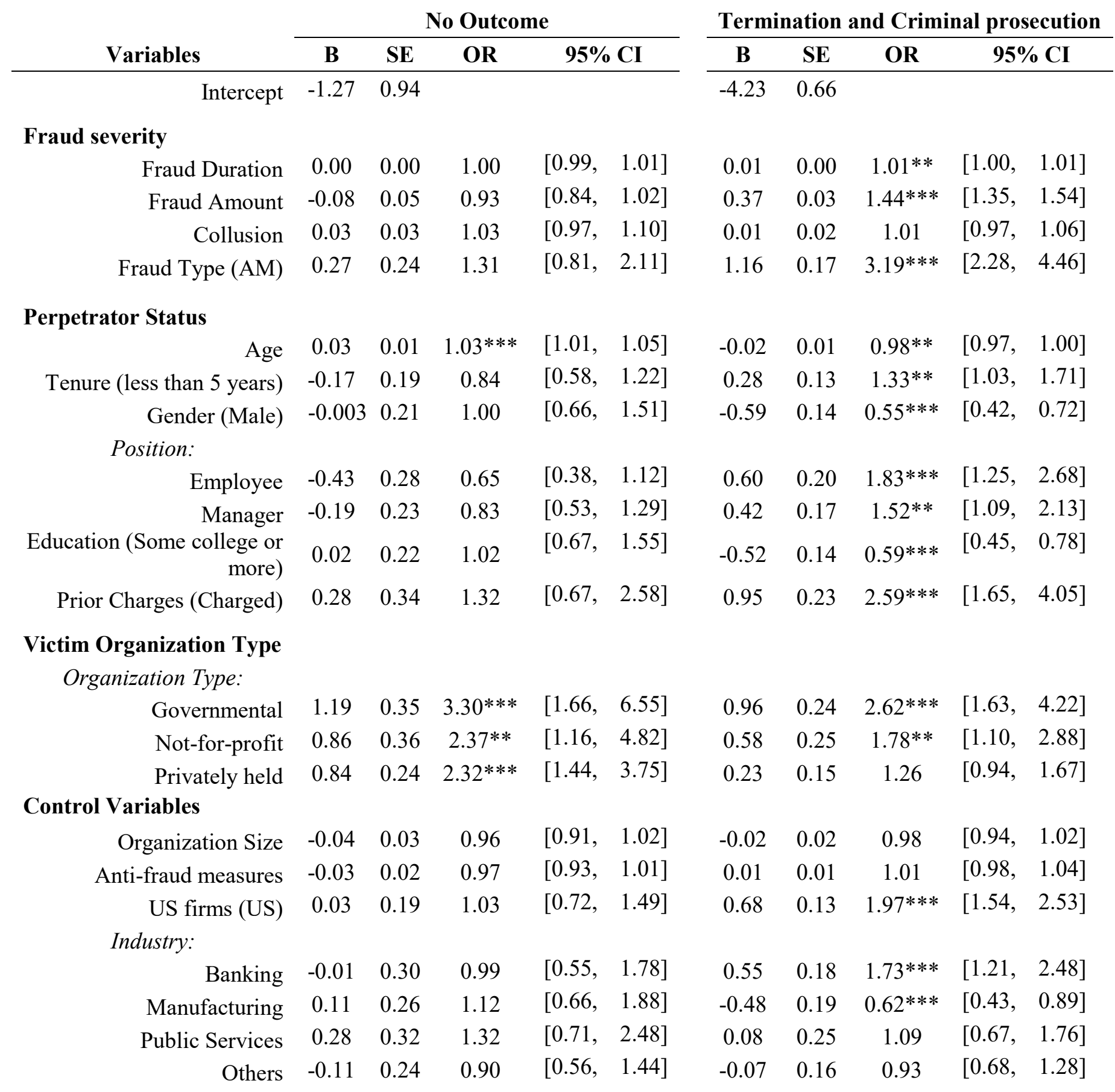

$*, * *, * * *$ Indicate $\mathrm{p}<0.1, \mathrm{p}<0.05$, and $\mathrm{p}<0.01$ levels, respectively, for the two-tailed test. 
Table 4 - 5: P's Aggregate Expectations

Paths

6 positive; 0 negative

5 positive; 1 negative

4 positive; 2 negative

3 positive; 3 negative

2 positive; 4 negative

1 positive; 5 negative

0 positive; 6 negative
P's Aggregate Expectation

0.9834

0.4722

0.19

0.00

$-0.19$

$-0.4722$

$-0.9834$ 
Table 4 - 6: Multinomial Logit Regression for Outcome Pursued and Fraud Severity, Perpetrator Status and Victim Organization Type.

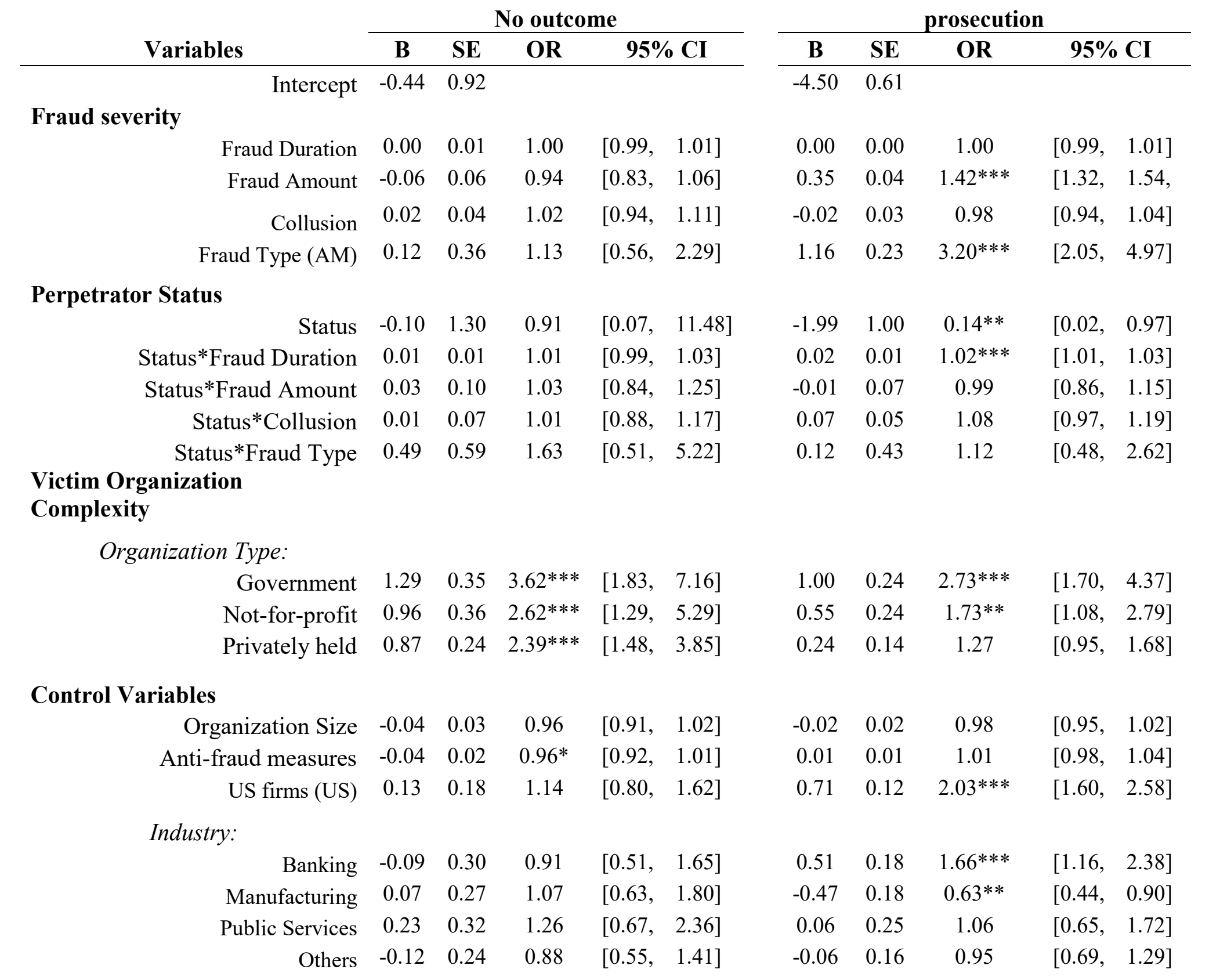

Termination and criminal 
Table 4 - 7: Multinomial Logit Regression for Outcome Pursued and Fraud Severity, Perpetrator Status and Victim Organization Type.

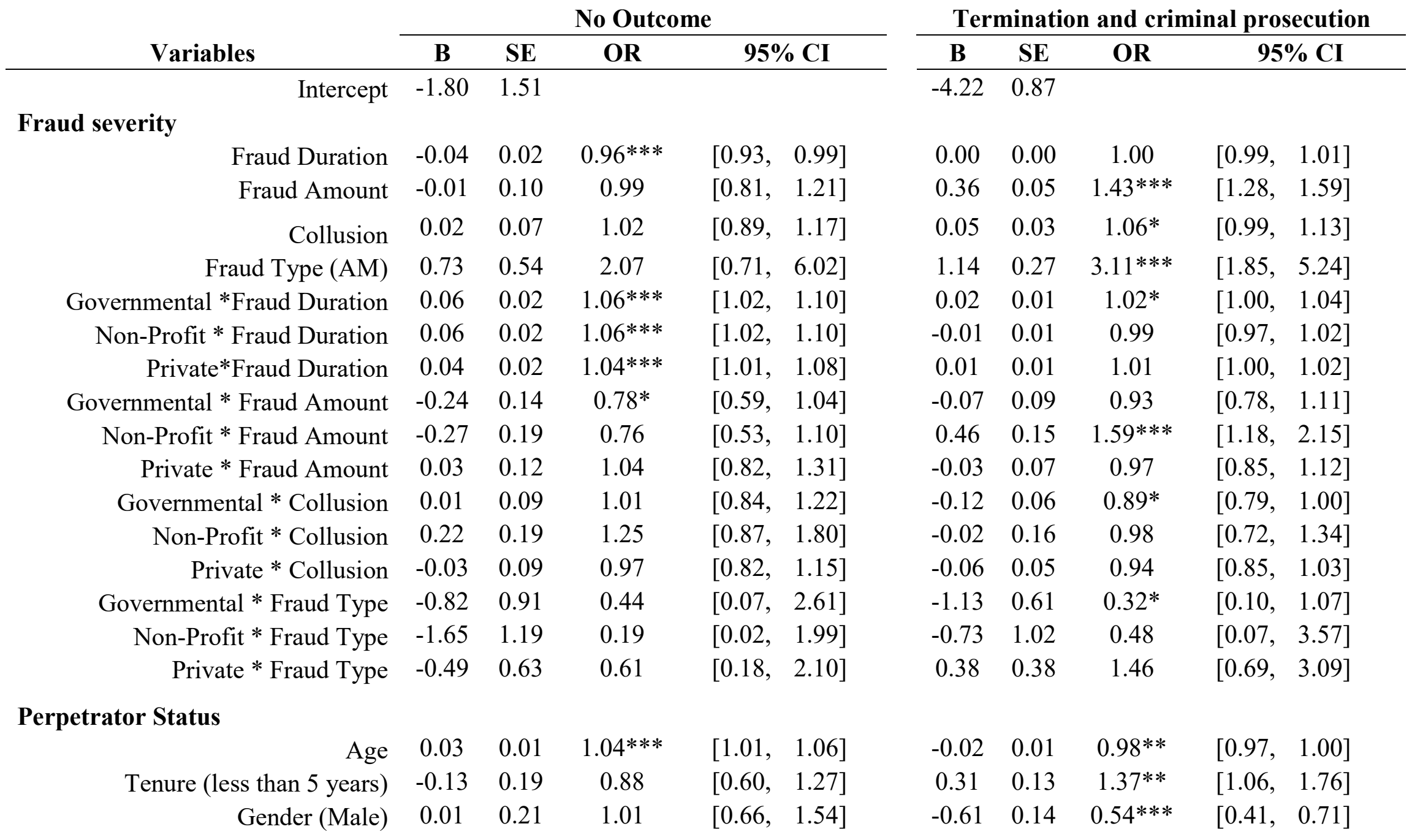


Position:

$\begin{array}{rccccccccc}\text { Employee } & -0.38 & 0.28 & 0.69 & {[0.40,1.19]} & 0.61 & 0.20 & 1.85^{* * *} & {[1.25,} & 2.73] \\ \text { Manager } & -0.14 & 0.23 & 0.87 & {[0.56,1.37]} & 0.43 & 0.17 & 1.53^{* *} & {[1.09,} & 2.16] \\ \text { ge or more) } & 0.04 & 0.22 & 1.04 & {\left[\begin{array}{lll}0.68, & 1.59\end{array}\right]} & -0.53 & 0.14 & 0.59 * * * & {[0.45,} & 0.77] \\ \text { (Charged) } & 0.28 & 0.35 & 1.33 & {\left[\begin{array}{ll}0.67, & 2.63\end{array}\right]} & 0.98 & 0.23 & 2.66^{* * *} & {[1.69,} & 4.20]\end{array}$

\section{Victim Organization Complexity}

Organization Type:

$\begin{array}{lcccccccccc}\text { Governmental } & 3.46 & 1.85 & 31.90^{*} & {[0.84,} & 1209.84] & 2.70 & 1.24 & 14.82 * * & {[1.31,} & 167.85] \\ \text { Not-for-profit } & 3.70 & 2.22 & 40.60^{*} & {[0.52,} & 3146.78] & -3.57 & 1.84 & 0.03 * & {[0.00,} & 1.03] \\ \text { Privately held } & 0.12 & 1.55 & 1.13 & {[0.05,} & 23.42] & 0.24 & 0.94 & 1.27 & {[0.20,} & 8.03]\end{array}$

\section{Control Variables}

\begin{tabular}{|c|c|c|c|c|c|c|c|c|c|c|}
\hline Organization Size & -0.04 & 0.03 & 0.96 & {$[0.90$,} & $1.02]$ & -0.02 & 0.02 & 0.98 & {$[0.95$,} & $1.02]$ \\
\hline Anti-fraud measures & -0.03 & 0.02 & 0.97 & {$[0.93$,} & $1.02]$ & 0.01 & 0.02 & 1.01 & {$[0.98$,} & $1.04]$ \\
\hline US firms (US) & 0.02 & 0.19 & 1.02 & {$[0.70$,} & $1.48]$ & 0.67 & 0.13 & $1.95 * * *$ & {$[1.52$,} & 2.50] \\
\hline \multicolumn{11}{|l|}{ Industry: } \\
\hline Banking & -0.11 & 0.31 & 0.90 & {$[0.49$,} & $1.64]$ & 0.53 & 0.19 & $1.70 * * *$ & {$[1.18$,} & $2.45]$ \\
\hline Manufacturing & 0.12 & 0.27 & 1.12 & {$[0.67$,} & $1.90]$ & -0.44 & 0.19 & $0.64 * *$ & {$[0.45$,} & $0.93]$ \\
\hline Public Services & 0.29 & 0.33 & 1.34 & {$[0.69$,} & $2.58]$ & 0.06 & 0.26 & 1.07 & {$[0.65$,} & $1.76]$ \\
\hline Others & -0.16 & 0.24 & 0.86 & {$[0.53$,} & $1.38]$ & -0.09 & 0.16 & 0.91 & {$[0.67$,} & $1.25]$ \\
\hline
\end{tabular}

$*, * *, * * *$ Indicate $p<0.1, p<0.05$, and $p<0.01$ levels, respectively, for the two-tailed test. 


\section{CHAPTER FIVE: CONCLUSION}

This dissertation examines the broad and complex topic of occupational fraud which has implications for the accounting research and practice. The first study concentrates on the pre-fraud period whereas the remaining two studies focus on the post-fraud period. More specifically, the first study examines the role of executive compensation, in the years leading up to fraud detection, in perpetrator's decision to commit fraud, and the other two studies examine the regulatory entities' findings against perpetrators and victim organizations' outcome against principal perpetrators after fraud is detected.

The first study examines the association between executive compensation and financial statement fraud. We find evidences that fraud firms prefer to pay their executives with higher levels of equity compensation years before the beginning of the misreporting period. The difference in equity compensation is driven almost entirely by option grants specifically. These differences begin in the first year of an executive's tenure and remain over their tenure at the firm. Our results suggest that both firm-level and executive-level compensation preferences combined with the idiosyncratic portfolio management all contribute jointly to an increased reporting risk. These findings contribute to prior literature by replicating their compensation differences between misreporting and control firms. Further, it provides insight into how these compensation differences developed in the years leading up to the fraud. It also contributes to practitioners by suggesting that the reporting risk could be reduced by encouraging executives to diversify their portfolios throughout their tenure as their firm-based wealth increases from accumulated compensation over time.

The second study examines the accountability framework employed by the SEC in their auditor related findings. More specifically, it examines the association of fraud characteristics and 
the SEC's auditor related findings. The results indicate a weak association between the fraud characteristics and the SEC's findings, but a strong association between Big $\mathrm{N}$ auditor and the SEC's finding. Therefore, the evidences are more consistent with a process-reward accountability framework than an outcome-penalty accountability framework. This conclusion speaks to independent auditors who are constantly managing auditing risk. It indicates that audit process matters more than the audit outcome. The findings also contribute to accounting literature as this study examines three different auditor related findings unlike prior literature which examines only two.

The third study examines the outcomes pursued by the victim organizations against the principal perpetrators in occupational fraud cases. We conclude that the fraud outcome is determined not only by the severity of the fraud act, but also by who committed the act and who the victim is. This study contributes not only to the accounting literature but also to criminology literature by considering the perpetrator's status characteristics and the victim organization type as moderators to the relationship between crime severity and punishment severity. It also offers antifraud professionals, such as forensic accounting and fraud examination professionals, an insight into the factors they would consider before advising their clients on what outcome to pursue against principal perpetrators. This information may also aid victim organization firms in the design of their internal controls.

Occupational fraud still prevails in the business world and results in severe consequences not only to the fraud victims but also for the fraud perpetrators. This dissertation aims at providing a better understanding of the broad topic of occupational fraud in order to benefit both the academic researchers and the practitioners. 